and Environment

Manuscript Number: BAE-D-15-01421R1

Title: A review of high temperature cooling systems in tropical buildings

Article Type: Review Article

Keywords: High Temperature Cooling; Radiant cooling; air-water system; DOAS; energy saving; Tropical Buildings

Corresponding Author: Mr. Esmail Mahmoudi Saber, Ph.D. Student

Corresponding Author's Institution: National University of Singapore

First Author: Esmail Mahmoudi Saber, Ph.D. Student

Order of Authors: Esmail Mahmoudi Saber, Ph.D. Student; Kwok Wai Tham, PhD; Hansjürg Leibundgut, PhD 
National University of Singapore

4 Architecture Drive

Singapore, 117566

25 November 2015

Dear Sir/Madam,

Editor of Building and Environment Journal,

Please find enclosed to this letter the revised version of the manuscript entitled as "A review of high temperature cooling systems in tropical buildings" for exclusive consideration of publication in the Building and Environment Journal. This research has been conducted in the department of building in National University of Singapore. It is an extension of a research project which was based in Singapore-ETH Centre, co-funded by the Singapore National Research Foundation (NRF) and ETH Zurich in collaboration with department of building at National University of Singapore.

In this review article, the recent studies on the applications of high temperature cooling systems in the tropical context have been reviewed. The outcomes of this research brought new insights into different aspects of implementing this cooling strategy in tropical buildings. The objectives of this paper are aligned with focus of the journal regarding high performance buildings and sustainable built environment. This article should be of interest to a broad readership including those interested in high temperature cooling and radiant-convective systems in buildings. Please find the details of report and results of the research in the manuscript.

Thanks for considering this article. Please address all correspondence regarding this manuscript to me through my email (emsaber@u.nus.edu) or contact me on phone $(+65-$ 92279136) if you need further information.

Regards,

Esmail M. Saber 
National University of Singapore

4 Architecture Drive

Singapore, 117566

25 November 2015

Dear Sir/Madam,

Editor of Building and Environment Journal,

We would like to appreciate the efforts of reviewers for examining the paper and providing these constructive and helpful comments. Please find our response to the raised comments and suggestions listed in the below table.

Best regards,

Esmail M. Saber

\begin{tabular}{|c|c|c|}
\hline No. & Editor's Comments & \\
\hline & Reviewer\#2 & \\
\hline 1 & $\begin{array}{l}\text { Page 5: Line } 7 \text { : supply temperature in } \\
\text { the range of } 18 \text { to } 24{ }^{\circ} \mathrm{C} \ldots \text { At this } \\
\text { supply temperature range would there } \\
\text { be sufficient dehumidification to } \\
\text { avoid condensation }\end{array}$ & $\begin{array}{l}\text { As implied in the question, the } \\
\text { dehumidification provided by air system } \\
\text { drops for higher supply air temperature. } \\
\text { The authors of the cited paper did not } \\
\text { mention any concern regarding to } \\
\text { condensation on radiant panel surface. This } \\
\text { could be due to the low latent load of the } \\
\text { lab or low dew point level at supply air. } \\
\text { Nevertheless, the PMV of indoor space was } \\
\text { not in comfortable range at supply air } \\
\text { temperature of } 24{ }^{\circ} \mathrm{C} \text {. These explanations } \\
\text { were added to the manuscript. }\end{array}$ \\
\hline 2 & $\begin{array}{l}\text { Page 18: line } 1-5 \text {. For spaces... rather } \\
\text { than DOAS.. I would like to have } \\
\text { author's view on this claim. }\end{array}$ & $\begin{array}{l}\text { This statement was made based on the fact } \\
\text { that reconditioning of indoor air is a } \\
\text { common practice in conventional ACMV } \\
\text { system in commercial buildings with } \\
\text { conventional façade airtightness. In high } \\
\text { temperature cooling design, sensible load } \\
\text { could be handled by radiant/convective } \\
\text { cooling while latent load needs to be still } \\
\text { handled by air system. If latent load of } \\
\text { space including infiltration of humid } \\
\text { outdoor air and human load could be }\end{array}$ \\
\hline
\end{tabular}




\begin{tabular}{|c|c|c|}
\hline & & $\begin{array}{l}\text { handled by low volume supply air of } \\
\text { DOAS, there would be no need to } \\
\text { recondition indoor air. This explanation } \\
\text { was added to the manuscript. }\end{array}$ \\
\hline \multirow[t]{2}{*}{3} & $\begin{array}{l}\text { Page 29: line } 29 . . \text { best to be kept near } \\
\text { minimum.. This may not be true in all } \\
\text { the cases. This depends on several } \\
\text { parameters, including the internal } \\
\text { load, latent loads etc. }\end{array}$ & $\begin{array}{l}\text { We agree with the comment. The statement } \\
\text { revised to make it clear that from energy } \\
\text { efficiency point of view, it is best to keep } \\
\text { the ventilation rate near the minimum } \\
\text { requirements of standards. In spaces with } \\
\text { high latent load, supply air volume to space } \\
\text { may be required to exceed this minimum } \\
\text { requirement. This explanation was added to } \\
\text { the manuscript. }\end{array}$ \\
\hline & Reviewer\#3 & \\
\hline 1 & $\begin{array}{l}\text { The title of article } \\
\text { It is better to use the term "high } \\
\text { temperature radiant cooling systems" } \\
\text { because generally high temperature } \\
\text { cooling means the radiant cooling } \\
\text { system. }\end{array}$ & $\begin{array}{l}\text { The term of "high temperature cooling } \\
\text { system" has been used in this paper to } \\
\text { include all the systems which use higher } \\
\text { chilled water temperature than conventional } \\
\text { system. Heat transfer in HTC systems like } \\
\text { radiant panel or slab cooling happens } \\
\text { mostly through radiation while active } \\
\text { chilled or passive chilled beam are mainly } \\
\text { convective based. If we replace this term } \\
\text { with "high temperature radiant cooling } \\
\text { system", it would not be inclusive of } \\
\text { convective based high temperature cooling } \\
\text { systems like active chilled beam or passive } \\
\text { chilled beam which were investigated in } \\
\text { this review paper. }\end{array}$ \\
\hline 2 & $\begin{array}{l}\text { In chapter 2, you can include the } \\
\text { activity of IEA Annex } 59 \text { and ISO } \\
\text { standardization for radiant heating } \\
\text { and cooling system. You can include } \\
\text { some references such as ISO } \\
\text { standards. }\end{array}$ & $\begin{array}{l}\text { The information regarding activities in IEA } \\
\text { ECBCS group on application of low exergy } \\
\text { cooling systems in building was added to } \\
\text { the manuscript. The ISO } 11855 \text { guideline } \\
\text { on design, dimensioning, installation and } \\
\text { control of radiant cooling system has also } \\
\text { been referenced. }\end{array}$ \\
\hline 3 & $\begin{array}{l}\text { It is better to include the difference } \\
\text { between temperate climate and } \\
\text { tropical climate by analyzing the } \\
\text { standard climate data. }\end{array}$ & $\begin{array}{l}\text { A graph has been added to the manuscript } \\
\text { to illustrate the temperature and dew point } \\
\text { variation during the year in the tropics as } \\
\text { well as in the dry and temperate climates } \\
\text { (Fig. 1). }\end{array}$ \\
\hline 4 & $\begin{array}{l}\text { It is better to focus on the specific } \\
\text { considerations for the application of } \\
\text { high temperature radiant cooling } \\
\text { system in tropical buildings. For this } \\
\text { purpose, the core findings of this } \\
\text { review article should be revised } \\
\text { accordingly. It is better to change the } \\
\text { core findings by the specific } \\
\text { considerations in tropical buildings }\end{array}$ & $\begin{array}{l}\text { More specific considerations regarding } \\
\text { implementation of high temperature cooling } \\
\text { in tropical buildings were added to the } \\
\text { manuscript. This information relates to the } \\
\text { tropical context on the basis of high dew } \\
\text { point level all the year round, avoiding } \\
\text { condensation risk, preference of locally } \\
\text { acclimatized occupants, low lift chiller } \\
\text { operational conditions, potential connection }\end{array}$ \\
\hline
\end{tabular}




\begin{tabular}{|l|l|l|}
\hline & $\begin{array}{l}\text { according to the different climate } \\
\text { condition. For example, due to the } \\
\text { very hot and humid climate } \\
\text { condition, thermal output from the } \\
\text { radiant surface can be restricted } \\
\text { according to the comfort and } \\
\text { condensation problems. }\end{array}$ & $\begin{array}{l}\text { to cooling tower and other related aspects to } \\
\text { HTC system operations in this climate. }\end{array}$ \\
\hline $\begin{array}{l}\text { In chapter 5, it is better to suggest the } \\
\text { schematic diagrams for the } \\
\text { application of high temperature } \\
\text { radiant cooling system in tropical } \\
\text { buildings, and compare the pros and } \\
\text { cons each other. And then you can } \\
\text { discuss the design and operation } \\
\text { guidelines. }\end{array}$ & $\begin{array}{l}\text { More explanations on the pros and cons of } \\
\text { various components and design strategies in } \\
\text { high temperature cooling implementation in } \\
\text { the tropics were added to the manuscript. } \\
\text { These aspects include potential energy } \\
\text { saving, thermal comfort, air quality, initial } \\
\text { and maintenance costs of different design } \\
\text { components and strategies. }\end{array}$ \\
\hline 6 & $\begin{array}{l}\text { In conclusions, it is better to suggest } \\
\text { the key findings for the application of } \\
\text { high temperature radiant cooling } \\
\text { system in tropical buildings. Now it } \\
\text { is a little bit general outcome. }\end{array}$ & $\begin{array}{l}\text { Most of the key findings of this review are } \\
\text { exclusive to the tropics, while some of them } \\
\text { are applicable to the temperate and dry } \\
\text { climates as well. The outcomes in the } \\
\text { conclusion are revised to indicate whether } \\
\text { that statement is applicable to the tropics } \\
\text { only. }\end{array}$ \\
\hline
\end{tabular}


Department of Building, National University of Singapore

4 Architecture Drive

Singapore, 117566

23 September 2015

Dear Sir/Madam,

Editor of Building and Environment Journal,

The core findings of this review paper could be summarized as follows,

- Studies on applications of high temperature cooling in the tropics were reviewed

- High temperature cooling can cut the air supply fan energy use by half

- A custom designed low lift chiller can further utilize the potential energy saving

- A detailed design/operation strategy of coupled air-water systems is essential

- Membrane based air to air heat exchanger showed promising results for this context

Regards,

Esmail M. Saber 


\title{
A review of high temperature cooling systems in tropical buildings
}

\author{
Esmail M. Saber*1,2 Kwok Wai Tham ${ }^{1}$ Hansjürg Leibundgut ${ }^{3}$ \\ ${ }^{1}$ Department of Building, School of Design and Environment, National University of Singapore, Singapore \\ ${ }^{2}$ Singapore-ETH Centre for Global Sustainability, Future Cities Laboratory, Swiss Federal Institute of Technology (ETH), Zurich, \\ Switzerland \\ ${ }^{3}$ Institute of Technology in Architecture, Swiss Federal Institute of Technology (ETH), Zurich, Switzerland \\ * Corresponding author. Tel.: +6592279136 \\ E-mail address: emsaber@u.nus.edu (Esmail M. Saber).
}

\section{Abstract}

High temperature cooling is gaining more attention in commercial buildings of the tropical climates where temperature and humidity is high all year round. In this air-water system, radiant-convective cooling is provided into conditioned space through using higher chilled water temperature compared to conventional all air system. Radiant cooling panel, radiant slab cooling, passive/active chilled beams are the main design strategies for implementing this concept into buildings. This paper reviewed and summarized the recent published papers on applications of high temperature cooling systems in tropical buildings. The reported outcomes and conclusions from these studies were extracted and discussed to get a better understanding on overall performance of the systems which are designed based on this concept. The potential energy saving of this strategy was estimated to be in the range of 6 to $41 \%$ depending on design strategies and operational scenarios of system. Comfortable and healthy indoor environment is achievable for this design when a parallel air system satisfies latent load and ventilation requirement of space. Low air movement was the only reported comfort concern for the tropicsthis design since locally acclimatized occupants in the tropics prefer higher air movement compared to dry and temperate climates. Regarding the parallel air system strategy, DOAS with ceiling supply-ceiling exhaust was - is suggested to be the best choice for eouplingto be coupled with high temperature cooling system. In addition, incorporation of energy recovery systems like membrane based air to air heat exchanger into DOAS can improve the overall efficiency of this design. 
Keywords -High Temperature Cooling; Radiant cooling; air-water system; DOAS; energy saving; Tropical Buildings

\section{Abbreviations}

$\begin{array}{ll}\text { ACB } & \text { Active Chilled Beam } \\ \text { ACMV } & \text { Air Conditioning and Mechanical Ventilation } \\ \text { AHU } & \text { Air Handling Unit } \\ \text { CAV } & \text { Constant Air Volume } \\ \text { CC } & \text { Chilled Ceiling } \\ \text { CFD } & \text { Computational Fluid Dynamics } \\ \text { CE } & \text { Ceiling Exhaust } \\ \text { COP } & \text { Coefficient of Performance } \\ \text { CHWS } & \text { Chilled Water Supply } \\ \text { CHWR } & \text { Chilled Water Return } \\ \text { CS } & \text { Ceiling Supply } \\ \text { DDOAS } & \text { Decentralized Dedicated Outdoor Air System } \\ \text { DOAS } & \text { Dedicated Outdoor Air System } \\ \text { DV } & \text { Displacement Ventilation } \\ \text { EA } & \text { Exhaust Air } \\ \text { ERS } & \text { Energy Recovery System } \\ \text { FS } & \text { Floor Supply } \\ \text { IAQ } & \text { Indoor Air Quality } \\ \text { HTC } & \text { High Temperature Cooling } \\ \text { HTCW } & \text { High Temperature Chilled Water } \\ \text { HVAC } & \text { Heating, Ventilation, and Air Conditioning } \\ \text { LTC } & \text { Low Temperature Cooling } \\ \text { LTCW } & \text { Low Temperature Chilled Water } \\ \text { MF } & \text { Mechanical Fan } \\ \text { MHX } & \text { Membrane Heat exchanger } \\ \text { NV } & \text { Natural Ventilation } \\ \text { OA } & \text { Outdoor Air } \\ \text { PCB } & \text { Passive Chilled Beam } \\ \text { PMV } & \text { Predicted Mean Vote } \\ \text { PPD } & \text { Predicted Percentage Dissatisfied } \\ \text { RA } & \text { Return Air } \\ \text { RAS } & \text { Recirculated Air System } \\ \text { RCS } & \text { Radiant Cooling System } \\ \text { RCP } & \text { Radiant Cooling Panel } \\ \text { RDD } & \text { Rotary Desiccant Dehumidifier } \\ \text { RSC } & \text { Radiant Slab Cooling } \\ \text { SA } & \end{array}$

\section{Introduction}

Our collective concern regarding to-the global warming is slowly changing the way we behave and act in different aspects of our lives in order to reduce our daily $\mathrm{CO}_{2}$ footprints. Governments started proactively encouraging communities and companies to implement green technologies at different sectors including building industry. In the tropical context where 
temperature and humidity are high all year round, air conditioning and mechanical ventilation systems (ACMV) is a necessity for commercial buildings. Several governmental and International reports in tropical countries revealed that ACMV system consumes around half of electricity use in commercial buildings [1]. Central all air system is the conventional cooling system in tropical buildings where central chilled water plant provides chilled water for air handling units which covers several thermal zones. The amount and temperature of conditioned air to each zone could be controlled by variable or constant air volume (VAV/CAV) through a user controlled thermostat located inside the conditioned space. High temperature cooling (HTC) concept introduces a new design by using higher temperature chilled water $\left(\approx 16{ }^{\circ} \mathrm{C}\right)$ compared to the conventional design $\left(\approx 6{ }^{\circ} \mathrm{C}\right)$. HTC design incorporates a water based system to provide sensible cooling in the conditioned space while a parallel air based system usually handles latent load and ventilation requirements of indoor space. The energy performance superiority of this design comes from the facts that water is a more efficient medium for heat transfer compared to air and high temperature chilled water can be provided at higher chiller COP.

The implications of HTC strategies like radiant cooling panel, radiant slab cooling, passive/active chilled beam have been extensively explored for the temperate and dry climates. Novoselac and Srebric [2] provided a dimensionless performance metric of chilled ceiling combined with displacement ventilation and concluded that it may or may not save energy compared to all air system depending on operational parameters like supply air temperature and outdoor flow rate. Tian and Love [3] conducted energy simulation analysis for application of radiant slab cooling and showed that energy saving potentials range between 10 to $40 \%$ for different climate types. In another study, Mumma [4] estimated that VAV costs about $29 \%$ more to operate compared to DOAS-RCP system for humid subtropical climate of 
Philadelphia in US. He also argued that it takes hours for condensation film to appear on radiant panel in the case occupancy level increases by a factor of 2 or 3 from design level [5].

The operational conditions and arrangements of HTC and air system in the indoor space play an important role on indoor air characteristic indices like thermal stratification and ventilation effectiveness [6]. Chiang et al. [7] evaluated the performance of CC-DV for the subtropical climate of Taiwan and suggested supply temperature in the range of 18 to $24{ }^{\circ} \mathrm{C}$ to reduce thermal stratification in the space. No concern of condensation on radiant ceiling surface was reported for this range of supply temperature which could be due to the low dew point level at supply air or low latent load of the lab. Nevertheless, the PMV of indoor space was not in comfortable range at supply air of $24^{\circ} \mathrm{C}$. The results of their CFD simulation also showed that floor air supply in this design performs better than ceiling supply. On the contrary, Wang and Tian [8] concluded that ceiling delivery and ceiling exhaust is the optimized arrangement for a hybrid radiant cooling and DOAS system. Based on their findings, impact significance of design factors has an order of air supply temperature > panel coverage area > panel temperature > air supply volume. In addition, Schiavon et al. [9] found a strong correlation between indoor thermal stratification and average temperature of radiant panel surface for CC-DV design. The shift in cooling strategy from all air system to air-water system has also some impacts on heat gain level of buildings. It has been reported that there is an increase of building cooling load for the implemented case of radiant cooling system and efforts should be made to avoid direct sun shines on HTC system [10]. Feng et al. [11] developed a simulation tool to investigate the magnitude of this cooling load difference between radiant cooling and all air system. They found 5 to $15 \%$ increase in average diurnal cooling load compared to all air system and the level of increase was predicted to be higher for floor cooling system. 
In this paper, the reported studies in the literature on the applications of high temperature cooling in the tropical context were reviewed. The scope of this review was limited to the research studies conducted in or for the tropical climate based on the Köppen-Geiger climate classification [12]. The group A of this classification includes tropical rainforest, tropical monsoon, and tropical wet and dry (savanna) climates which are characterized as high temperatures $\left(\geq 18{ }^{\circ} \mathrm{C}\right)$ and precipitations all year round except for dry season in monsoon and savanna climates. These climates usually occur in the areas near the equator and cover various countries in Asia, Africa and America like Singapore, Malaysia, Thailand, Indonesia, Philippine, Brazil, and India. The average monthly variation of temperature and dew point for three climates of tropical rainforest (Singapore, Kuala Lumpur, Jakarta and etc.), hot desert (Phoenix, Doha, Dubai and etc.) and warm temperate (Hanoi, Hong Kong, Taipei and etc.) are illustrated in Fig. 1. In the tropical climate of Singapore, temperature and dew point remain almost unchanged in the course of a year while in two other cities there is a clear warm season which happens between May to September. The warm temperate climate of Hanoi exhibits similar profile to the tropics during warm season where dew point is close to $25^{\circ} \mathrm{C}$. On the other hand, at hot desert climate of Phoenix in Arizona, dew point level is unlikely to exceed $\underline{15{ }^{\circ} \mathrm{C}}$ 


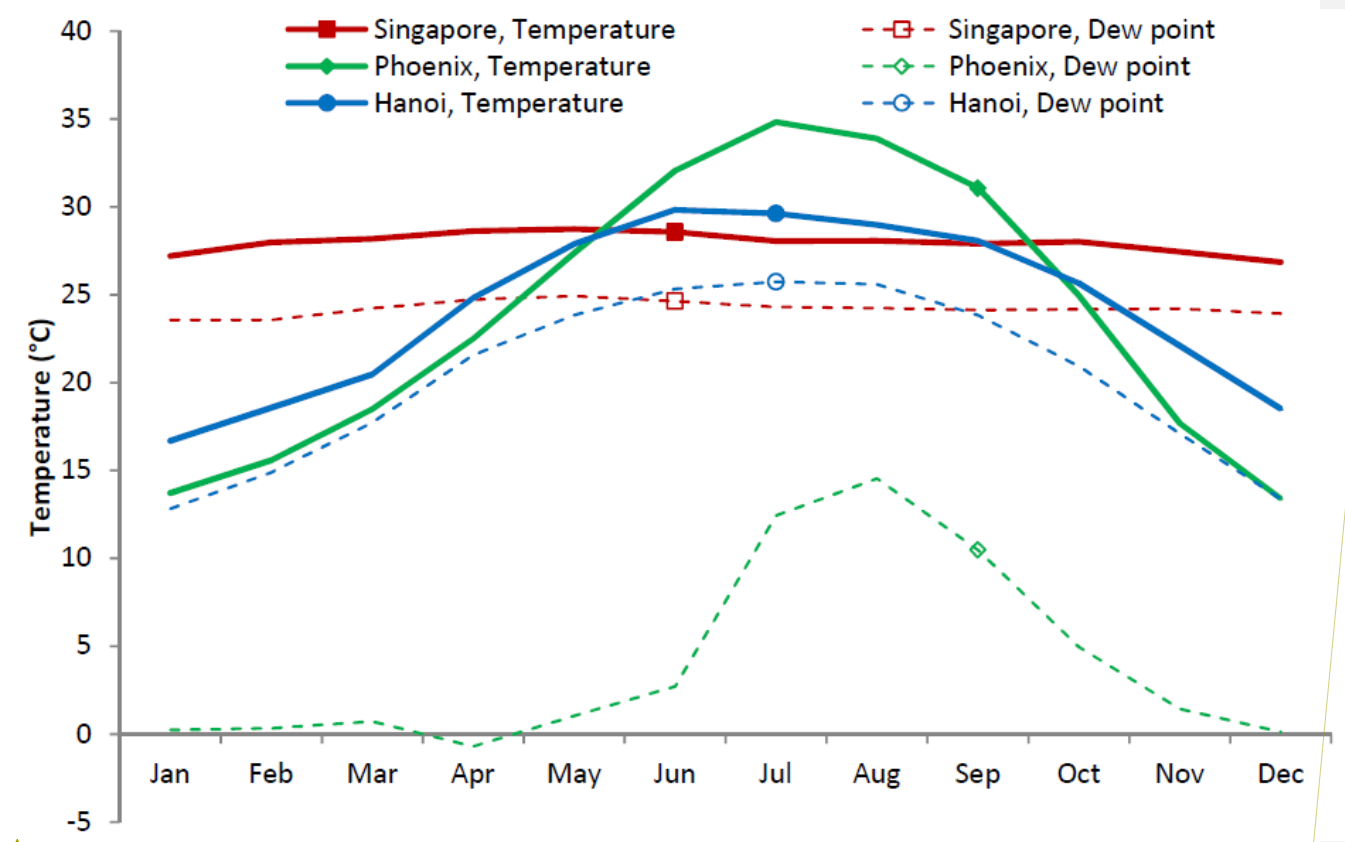

Formatted: Font: $12 \mathrm{pt}$

Fig. 1 The monthly variation of temperature and dew point for three cities of Singapore

Formatted: Centered (average of 1956-2015), Phoenix (average of 1948-2015) and Hanoi (average of 1959-2015)

\section{$[13]$}

Formatted: Font: $12 \mathrm{pt}$

The google scholar website has been chosen as the main platform and searches were conducted based on combined keywords of "high temperature cooling", "radiant cooling", "slab cooling", "chilled beam", "tropics" and "hot and humid". Thirty eight 38 papers on high temperature cooling system in the tropics and 45 papers on generic applications of HTC have been selected in the early stages. Based on relevance and originality of investigations, 27 and 17 papers were chosen for final investigation respectively for tropical and generic applications of HTC. The outcomes and conclusions from the reported studies were extracted and discussed on different aspects of HTC applications including energy saving, thermal comfort, design strategies and operational scenarios. A collection of design strategies and system components was introduced for efficient implementation of high temperature cooling systems in tropical buildings based on the collected information from the papers. 


\section{High temperature cooling in tropical buildings}

\subsection{Energy Saving Potential}

High temperature cooling systems have the potential to reduce power consumption of ACMV systems in buildings by using high temperature chilled water as heat transfer medium. In the tropical context, high humidity ambient air condition requires a more advanced design and control strategy in order to avoid condensation risk. Different amounts of energy saving was reported in the literature for the implementation of high temperature cooling systems in the tropics. The percentages of energy saving for the main reported studies in the literature are listed in Table 1. Majority of studies found the HTC systems more energy efficient compared to the conventional system. The level of savings ranged between 6 to $41 \%$ while in some design or operational scenarios, this concept consumed even more energy. The conventional systems in the tropics are usually central all air system for office use and split unit air conditioner for residential applications.

Table 1 List of reported studies in the literature on high temperature cooling systems applications in tropical buildings

\begin{tabular}{|c|c|c|c|c|c|c|c|}
\hline $\begin{array}{l}\text { Authors } \\
\text { (year) }\end{array}$ & $\begin{array}{c}\text { HTC } \\
\text { system }\end{array}$ & $\begin{array}{c}\text { Air system } \\
\text { / } \\
\text { distribution } \\
\end{array}$ & $\begin{array}{c}\text { City / Climate } \\
\text { Type }\end{array}$ & $\begin{array}{l}\text { Investigation } \\
\text { approach }\end{array}$ & $\begin{array}{c}\text { Supply } \\
\text { water to } \\
\text { HTC } \\
\end{array}$ & $\begin{array}{l}\text { Energy } \\
\text { saving }\end{array}$ & \\
\hline \multirow{3}{*}{$\begin{array}{l}\text { Ameen and } \\
\text { Khizir [14][13] }\end{array}$} & \multirow{3}{*}{$\mathrm{RCP}$} & \multirow{3}{*}{ RDD/DV } & \multirow{3}{*}{$\begin{array}{c}\text { Pulau Pinag, } \\
\text { Malaysia / } \\
\text { Tropical } \\
\text { rainforest } \\
\end{array}$} & \multirow{3}{*}{$\begin{array}{c}\text { Experimental } \\
\text { setup in a test } \\
\text { chamber }\end{array}$} & $\begin{array}{l}13^{\circ} \mathrm{C} \\
\text { (panel }\end{array}$ & \multirow{3}{*}{$\begin{array}{l}-51 \% \\
\text { to } 35 \%\end{array}$} & \\
\hline & & & & & surface & & Formatted: Font: $12 \mathrm{pt}$ \\
\hline & & & & & $\left.15-18^{\circ} \mathrm{C}\right)$ & & Formatted: Font: $10 \mathrm{pt}$ \\
\hline \multirow{2}{*}{$\begin{array}{l}\text { Kosonen and } \\
\text { Tan }[15][14]\end{array}$} & \multirow{2}{*}{$\mathrm{ACB}$} & \multirow{2}{*}{$\begin{array}{c}\text { DOAS/CS- } \\
\mathrm{CE}\end{array}$} & \multirow{2}{*}{$\begin{array}{c}\text { Singapore / } \\
\text { Tropical } \\
\text { rainforest }\end{array}$} & \multirow{2}{*}{$\begin{array}{c}\text { Field } \\
\text { measurement in } \\
\text { a ease study }\end{array}$} & \multirow{2}{*}{$16-17^{\circ} \mathrm{C}$} & \multirow{2}{*}{ NA } & \\
\hline & & & & & & & Formatted: Font: $12 \mathrm{pt}$ \\
\hline \multirow{3}{*}{$\begin{array}{c}\text { Vangtook and } \\
\text { Chirarattanano } \\
n \\
{[16,17][15,16]}\end{array}$} & \multirow{3}{*}{$\mathrm{RCP}$} & \multirow{3}{*}{ MF } & \multirow{3}{*}{$\begin{array}{c}\text { Central } \\
\text { Thailand / } \\
\text { tropical } \\
\text { savanna }\end{array}$} & \multirow{3}{*}{$\begin{array}{c}\text { Experimental } \\
\text { setup and } \\
\text { Building energy } \\
\text { modeling }\end{array}$} & \multirow{3}{*}{$24-25^{\circ} \mathrm{C}$} & \multirow{3}{*}{$\begin{array}{l}-100 \% \\
\text { to } 6 \%\end{array}$} & Formatted: Font: $10 \mathrm{pt}$ \\
\hline & & & & & & & \\
\hline & & & & & & & Formatted: Font: $12 \mathrm{pt}$ \\
\hline \multirow{2}{*}{$\begin{array}{l}\text { Wahed et al. } \\
[18], 17]\end{array}$} & \multirow{2}{*}{$\mathrm{ACB}$} & \multirow{2}{*}{ RDD } & \multirow{2}{*}{$\begin{array}{l}\text { Singapore / } \\
\text { Tropical } \\
\text { rainforest }\end{array}$} & \multirow{2}{*}{$\begin{array}{l}\text { Building Energy } \\
\text { modeling }\end{array}$} & \multirow{2}{*}{$18^{\circ} \mathrm{C}$} & \multirow{2}{*}{$\begin{array}{l}10 \text { to } \\
20 \%\end{array}$} & Formatted: Font: $10 \mathrm{pt}$ \\
\hline & & & & & & & Formatted: Font: $12 \mathrm{pt}$ \\
\hline
\end{tabular}




\begin{tabular}{|c|c|c|c|c|c|c|c|}
\hline \multirow[t]{2}{*}{$\begin{array}{l}\text { Binghooth and } \\
\text { Zainal [19],18] }\end{array}$} & \multirow[t]{2}{*}{$\mathrm{RCP}$} & \multirow[t]{2}{*}{ RDD } & \multirow{2}{*}{$\begin{array}{l}\text { Penang, } \\
\text { Malaysia / } \\
\text { Tropical } \\
\text { rainforest } \\
\end{array}$} & \multirow[t]{2}{*}{$\begin{array}{c}\text { Experimental } \\
\text { setup in a test } \\
\text { chamber }\end{array}$} & \multirow{2}{*}{$\begin{array}{c}\begin{array}{c}6-10{ }^{\circ} \mathrm{C} \\
(\text { panel }\end{array} \\
\text { surface } \\
14-18^{\circ} \mathrm{C} \text { ) }\end{array}$} & \multirow[t]{2}{*}{ NA } & Formatted: Font: $12 \mathrm{pt}$ \\
\hline & & & & & & & Formatted: Font: $10 \mathrm{pt}$ \\
\hline $\begin{array}{l}\text { Saber et al. } \\
{[20][19]}\end{array}$ & \multirow{4}{*}{$\mathrm{RCP}$} & \multirow{4}{*}{$\begin{array}{c}\text { DDOAS/FS } \\
-\mathrm{CE}\end{array}$} & \multirow{4}{*}{$\begin{array}{l}\text { Singapore / } \\
\text { Tropical } \\
\text { rainforest }\end{array}$} & \multirow{4}{*}{$\begin{array}{c}\text { Experimental } \\
\text { setup in a test } \\
\text { chamber }\end{array}$} & \multirow{3}{*}{$\begin{array}{c}17-19^{\circ} \mathrm{C} \\
\text { (panel } \\
\text { surface }\end{array}$} & \multirow{3}{*}{ NA } & Formatted: Font: $12 \mathrm{pt}$ \\
\hline \multirow{3}{*}{$\begin{array}{l}\text { Meggers et al. } \\
\text { Inengar et al. } \\
\text { Ine] }\end{array}$} & & & & & & & Formatted: Font: $10 \mathrm{pt}$ \\
\hline & & & & & & & Formatted: Font: $12 \mathrm{pt}$ \\
\hline & & & & & $\left.18-22^{\circ} \mathrm{C}\right)$ & & Formatted: Font: $10 \mathrm{pt}$ \\
\hline & \multirow{4}{*}{ RSC } & \multirow{4}{*}{ VAV } & \multirow{4}{*}{$\begin{array}{c}\text { Kuala Lumpur, } \\
\text { Malaysia / } \\
\text { Tropical } \\
\text { rainforest } \\
\end{array}$} & \multirow{4}{*}{$\begin{array}{l}\text { Field } \\
\text { measurement in } \\
\text { two case studies }\end{array}$} & \multirow{4}{*}{$19^{\circ} \mathrm{C}$} & \multirow{4}{*}{ NA } & Formatted: Font: $12 \mathrm{pt}$ \\
\hline Yau and Hasbi & & & & & & & Formatted: Font: $10 \mathrm{pt}$ \\
\hline [23][22] & & & & & & & Formatted: Font: $12 \mathrm{pt}$ \\
\hline \multirow{4}{*}{$\begin{array}{c}\text { Tantiwichien } \\
\text { and Taweekun } \\
\end{array}$} & & & & & & & Formatted: Font: $10 \mathrm{pt}$ \\
\hline & \multirow[t]{3}{*}{$\mathrm{RCP}$} & \multirow[t]{3}{*}{$\mathrm{MF}$} & \multirow{3}{*}{$\begin{array}{l}\text { Songkhla, } \\
\text { Thailand / } \\
\text { tropical } \\
\text { monsoon }\end{array}$} & \multirow{2}{*}{$\begin{array}{c}\text { Field } \\
\text { measurement } \\
\text { and Building } \\
\text { energy }\end{array}$} & \multirow[t]{3}{*}{$25^{\circ} \mathrm{C}$} & \multirow[t]{3}{*}{$41 \%$} & \\
\hline & & & & & & & Formatted: Font: $12 \mathrm{pt}$ \\
\hline & & & & modeling & & & Formatted: Font: $10 \mathrm{pt}$ \\
\hline \multirow{2}{*}{$\begin{array}{l}\text { Sastry and } \\
\text { Rumsey } \\
[25] 24]\end{array}$} & \multirow{2}{*}{$\begin{array}{l}\text { RSC } \\
\text { and } \\
\text { PCB }\end{array}$} & \multirow[t]{2}{*}{ DOAS } & \multirow{2}{*}{$\begin{array}{c}\text { Hyderabad- } \\
\text { India / tropical } \\
\text { savanna } \\
\end{array}$} & \multirow{2}{*}{$\begin{array}{c}\text { Field } \\
\text { measurement in } \\
\text { a case study }\end{array}$} & \multirow[t]{2}{*}{$14{ }^{\circ} \mathrm{C}$} & $34 \%$ & \\
\hline & & & & & & & Formatted: Font: $12 \mathrm{pt}$ \\
\hline Nutprasert and & & & Bangkok, & Experimental & & & Formatted: Font: $10 \mathrm{pt}$ \\
\hline $\begin{array}{l}\text { Chaiwiwatwor } \\
\text { akul [26] } 25]\end{array}$ & $\mathrm{RCP}$ & MF-FCU & $\begin{array}{l}\text { tropical } \\
\text { savanna }\end{array}$ & $\begin{array}{c}\text { setup and } \\
\text { Building energy } \\
\text { modeling }\end{array}$ & $21-25^{\circ} \mathrm{C}$ & NA & Formatted: Font: $12 \mathrm{pt}$ \\
\hline Seshadri et al. & $\mathrm{RCP}$ & VAV & $\begin{array}{l}\text { Singapore / } \\
\text { Tropical }\end{array}$ & $\begin{array}{l}\text { Experimental } \\
\text { setup and }\end{array}$ & $15^{\circ} \mathrm{C}$ & & Formatted: Font: $10 \mathrm{pt}$ \\
\hline [27][26] & & & rainforest & Building energy & & $20 \%$ & Formatted: Font: $12 \mathrm{pt}$ \\
\hline & & & & modeling & & & Formatted: Font: $10 \mathrm{pt}$ \\
\hline Khan et al. & RSC & DOAS-FCU & $\begin{array}{l}\text { Hyderabad- } \\
\text { India / tropical }\end{array}$ & $\begin{array}{l}\text { Experimental } \\
\text { setup and }\end{array}$ & $<16^{\circ} \mathrm{C}$ & 17.5 to & \\
\hline$\underline{28]}, 27\}$ & KNe & & savanna & Building & & $30 \%$ & Formatted: Font: $12 \mathrm{pt}$ \\
\hline & & & & Simulation tools & & & Formatted: Font: $10 \mathrm{pt}$ \\
\hline
\end{tabular}

Compared to conventional system, air-water systems can potentially save energy through further use of water as heat transport medium in order to lower fan energy use and duct size. The heat capacity of water $\left(4.183 \mathrm{~kJ} /(\mathrm{kg} . \mathrm{K}) @ 20^{\circ} \mathrm{C}\right)$ is four times more than air $(1.005$ $\left.\mathrm{kJ} /(\mathrm{kg} . \mathrm{K}) @ 20{ }^{\circ} \mathrm{C}\right)$, and consequently the heat transfer exchange process is potentially more efficient with water. The main opportunity for energy saving in high temperature cooling design comes from downsizing the supply air fan. The radiant cooling system could satisfy some part of space sensible load which brings the chance to reduce the amount of supply air 
volume or even just to limit it to ventilation air. In one study in the tropics, Vangtook and Chirarattananon $[17][16]$ conducted annual energy simulations based on measured data in a 16 $\mathrm{m}^{2}$ laboratory space in which radiant cooling panels were implemented as active wall and ceiling panel. The results of simulations showed that total fan energy use can be cut to half by using radiant panel instead of conventional air conditioning concept. In another study, Khan et al. [28],27] investigated thermal performance and energy saving potential of radiant cooling system in commercial buildings of Hyderabad in India through CFD and energy simulations. Annual energy consumption data revealed that $70 \%$ of fan energy consumption can be reduced by implementing DOAS combined with slab cooling. While in both of reported studies, water pump energy use in radiant cooling system increased almost by three times, overall required energy for air circulation were much higher than water circulation. A research group in the tropical climate of Singapore introduced the idea of decentralized DOAS (DDOAS) combined with radiant cooling based on low exergy concept to bring chilled water closer to the conditioned space and further reduce the fan energy use [29,30], 28,29$]$. The Energy Conservation in Buildings and Community Systems (ECBCS) group of International Energy Agency (IEA) has provided several reports on implementation of low exergy cooling systems in buildings [31-33]. High temperature radiant slab cooling has been categorized in

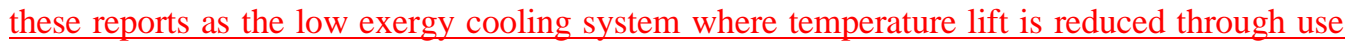
of higher chilled water temperature.

High temperature cooling concept can accommodate another aspect of energy saving in refrigeration system of chiller compared to all air system. Incorporating radiant cooling systems in buildings facilitates use of higher CHWS temperature which can potentially save energy by using a custom designed chiller for low temperature lift conditions. This higher evaporator temperature can reduce the compressor work because of lower operational temperature and pressure lift. The refrigeration cycles on pressure-enthalpy diagrams for two
Formatted: Font: $12 \mathrm{pt}$

Formatted: Font: $10 \mathrm{pt}$

Formatted: Font: $12 \mathrm{pt}$ Formatted: Font: $10 \mathrm{pt}$
Formatted: Font: $12 \mathrm{pt}$ Formatted: Font: $10 \mathrm{pt}$ 
cases of low temperature and high temperature cooling are shown in Fig. 12. As can be seen in

this graph, with reduction of lift between low and high pressure side of refrigeration cycle, the compressor performs less work. This graph indicates the efficiency superiority of HTC concept over conventional LTC air conditioning system.
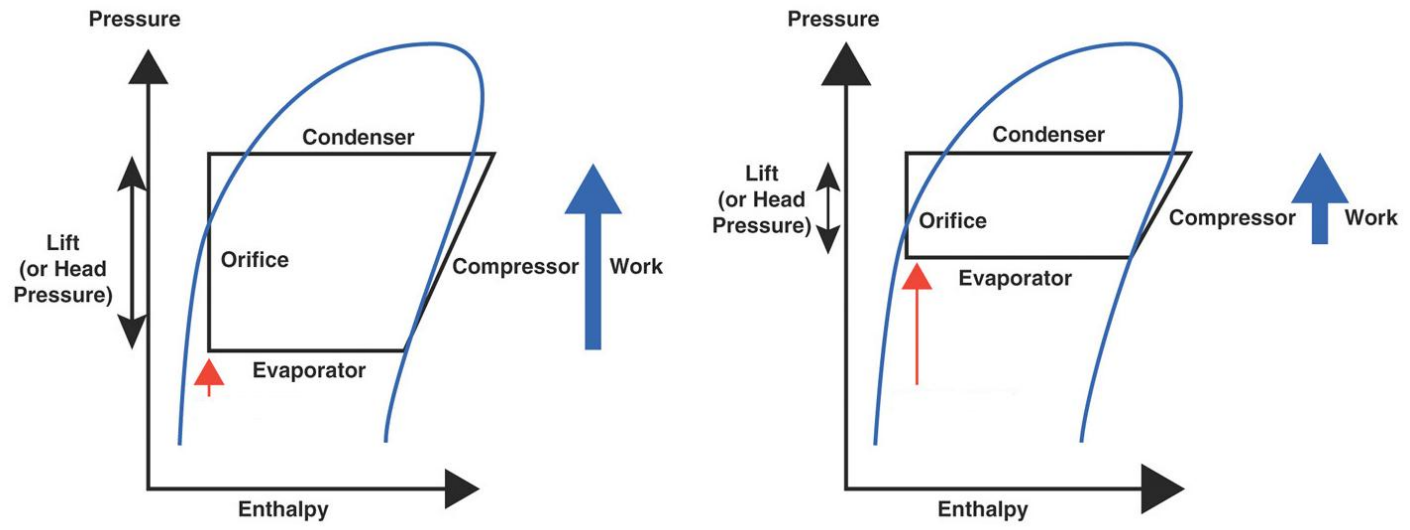

Fig. $1-2$ Impact of raising the evaporative temperature on refrigeration cycle diagram $[34][30]$

Formatted: Font: $12 \mathrm{pt}$

Formatted: Font: $10 \mathrm{pt}$

The high temperature cooling system is required to be complemented with a parallel air system to provide a comfortable and healthy indoor environment. In the tropical context, the air based system usually requires low temperature chilled water (LTCW) for an effective dehumidification. So, the combinations of LTCW and HTCW systems are necessary to truly exploit the potential energy saving of high temperature cooling concept. Saber et al. [20],19] implemented two chillers for the combination of DOAS-RCS in the tropical climate of Formatted: Font: $12 \mathrm{pt}$ Formatted: Font: $10 \mathrm{pt}$ Singapore. The schematic arrangement of these two chillers operating in parallel is shown in Fig. $2 \underline{3}$. The low temperature lift chiller provided HTCW for radiant panel and the second high lift chiller was designated for dehumidification of outdoor air in decentralized air supply units. In another study, Khan et al. $[28], 27]$ also considered two parallel chillers to provide chilled water for AHU and slab cooling systems, separately. The results showed that this design 
strategy can reduce the annual energy consumption of chillers by $20 \%$ compared to the conventional design.

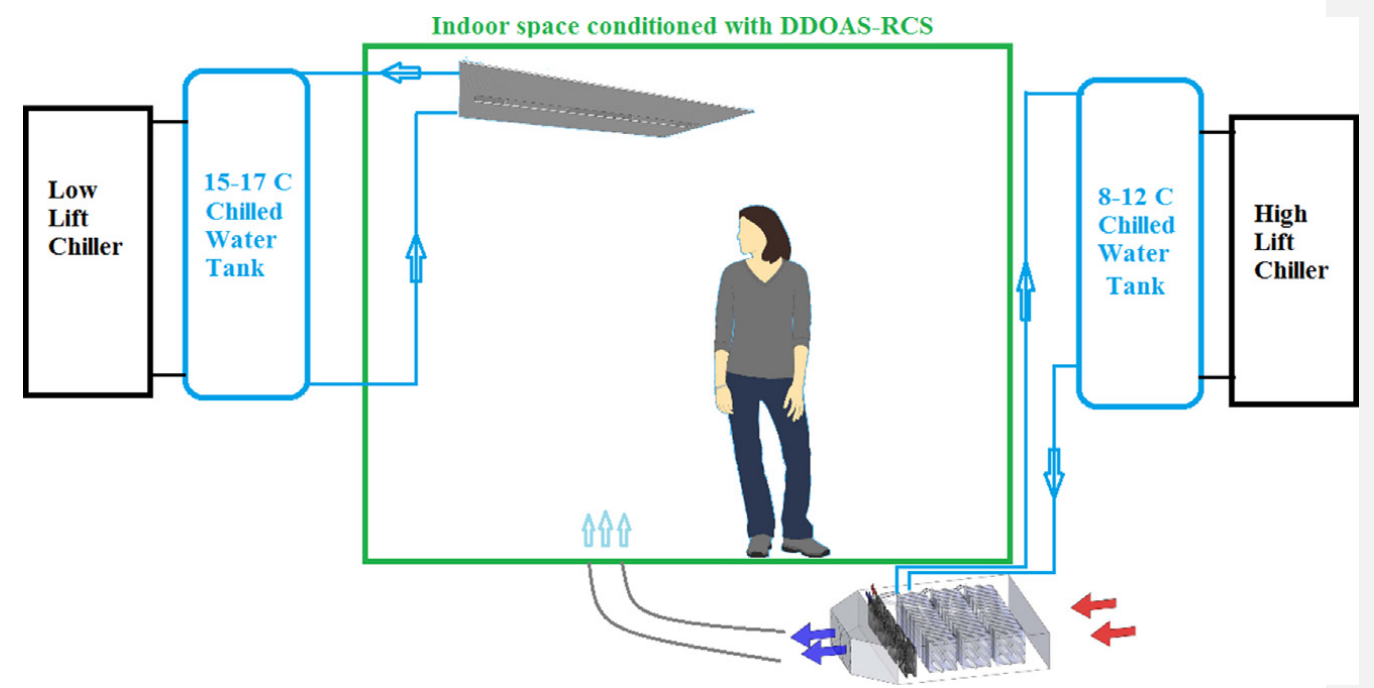

Fig. $2 \underline{3}$ Schematic diagram of decentralized DOAS-RCS with two separate low lift and high lift chillers [20][19]

\subsection{Thermal comfort and indoor air quality}

The main and only goal of any ACMV system is to provide comfortable and healthy indoor environment for occupants. Radiant heat transfer contribution has been enhanced in cooling of indoor space with high temperature cooling systems. This change results in a new type of conditioned space with lower air movement and mean radiant temperature compared to all air system. Thermal comfort and IAQ performance of this system could be evaluated based on the International standards and local guidelines in tropical countries. Fanger's PMV/PPD model is the most commonly used thermal comfort model in different climate types. However, the majority of comfort studies $\left[\begin{array}{ll}35-38\end{array}\right]\left[\begin{array}{ll}31 & 34\end{array}\right]$ in the tropics were concluded that locally acclimatized occupants have different perception compared to prediction of PMV model. So, a 
better understanding on actual perception of occupants in the tropics may be obtained by considering both the International and local standards' criteria.

Various design scenarios and control strategies have been exploited for implementation of HTC systems in tropical buildings. Thermal comfort was achieved adequately and accurately in some design scenarios while in other cases, indoor air was comfortable only under specific hours of day and occupant activities. In one strategy, chilled water supply temperature to $\mathrm{HTC}$ is kept around 24 to $25^{\circ} \mathrm{C}$ to be always above the outdoor dew point level in the tropical context. In parallel, fresh and humid outdoor air is brought into space through natural ventilation $(\mathrm{NV})$ or mechanical fan $(\mathrm{MF})$ for ventilation requirement or raising indoor air movement level. While condensation was avoided with this tactic, the high chilled water temperature put a restriction on capacity of HTC. This design strategy is suitable for spaces with low heat gain and only can provide comfortable indoor air space for night time residential applications under resting activity. From a favorable view, the required high temperature supply water for HTC can be provided through passive chilled water systems like cooling tower. Vangtook and Chirarattananon [16],15] investigated the application of radiant cooling in the tropical climate of Thailand by using natural air for ventilation and $24-25{ }^{\circ} \mathrm{C}$ chilled water for radiant panel. The results of experiments and simulation showed that the capacity of system was inadequate during hot period of the day and acceptable PMV only achieved during night time for a reclining person. In daytime occupancy and under office activity, personal fans have been considered to achieve thermal comfort [17],16]. In a similar study, Nutprasert and Chaiwiwatworakul [26],25] used supply chilled water temperature of $25 \mathrm{C}$ in radiant cooling panel combined with natural air for cooling of a space in Thailand. The results of Formatted: Font: $12 \mathrm{pt}$ Formatted: Font: $10 \mathrm{pt}$ building performance simulations showed that with this strategy, people feel warm or too warm, $71 \%$ of the time in the year.

Formatted: Font: $12 \mathrm{pt}$ Formatted: Font: $10 \mathrm{pt}$ Formatted: Font: $12 \mathrm{pt}$ Formatted: Font: $10 \mathrm{pt}$ 
The second and main stream design strategy in operating high temperature cooling system in the tropics is to keep CHWS temperature to HTC below outdoor dew point. A parallel conditioned air system is required to keep the indoor dew point level below HTC operational temperature. It can be seen from the list of studies in Table 1 that the supply water temperature for this strategy ranges between 14 to $21^{\circ} \mathrm{C}$ and the parallel air system could be DOAS or RAS. Almost all of the reported studies in the literature [15,21,22,25] $[14,20,21,24]$ concluded that adequate comfort condition can be achieved in the tropics with this design scheme. Kosonen and Tan $[15][14]$ conducted field measurements for an implemented case of active chilled beam in Singapore. They found that with off coil air temperature of $14{ }^{\circ} \mathrm{C}$ and supplied chilled water of $17{ }^{\circ} \mathrm{C}$, indoor air condition of $23{ }^{\circ} \mathrm{C}$ and $65 \%$ relative humidity could be achieved during daytime. In another field study, Sastry and Rumsey $[25][24]$ conducted a side by side comparison of radiant slab cooling and VAV all air system for the tropical climate of Hyderabad in India. Radiant cooling design provided higher satisfaction among occupants although ceiling fan was used in the indoor office space to raise the air movement level.

Low air movement in indoor space was the only identified comfort issue in the literature for application of radiant cooling systems in the tropics. There is no minimum air velocity requirement in the International standards like ASHRAE standard 55 [39][35] and ISO 7730 [40][36]. However, several local standards in tropical countries put some limit on the minimum acceptable air velocity. Local Singapore standard of SS 554 [41], 37$]$ recommended indoor air velocity to be in the range of 0.1 to $0.3 \mathrm{~m} / \mathrm{s}$. Malaysian local standard of MS $1525[42][38]$ also have the recommended range of 0.15 to $0.5 \mathrm{~m} / \mathrm{s}$ for air movement level in the occupied space. Yau and Hasbi [23][22] assessed thermal comfort and indoor air quality level in two green buildings in Malaysia in which radiant slab cooling were implemented. The objective measurements in the buildings revealed that indoor air condition provided by radiant slab cooling is compatible with the criteria of local and International standards. The only identified 
deficiency for this concept was low air movement which was below acceptable range in local standards. In another study, Kwong et al. [43], [39] conducted a thermal comfort survey in a green building in Malaysia with slab radiant cooling and found air velocity below the limit set by local guidelines.

\subsection{System design/operation strategy}

As explained in section 2.2, there are two main strategies in operating high temperature cooling systems in the tropics. In the first strategy, supply chilled water temperature to HTC is kept above outdoor dew point level and in the second strategy chilled water temperature is kept below outdoor dew point and dehumidification is required to avoid condensation. The main advantages of first scheme are utilizing passive chilled water system like cooling tower and less risk of condensation and system complexity. This design is mostly suitable for night time applications of residential buildings and personal fan has been advised to be used in parallel for day time applications in commercial buildings. The second strategy is able to provide adequate and accurate comfort condition under any indoor/outdoor scenarios. However, parallel operation of radiant cooling and air based dehumidification systems makes the design and control of overall system more complicated.

Radiant cooling panel (RCP), radiant slab cooling (RSC), active chilled beam (ACB) and passive chilled beam (PCB) are the common types of HTC strategies. Each system has its own advantages and drawbacks which makes it more suitable for some applications. RCP is a temperature controlled surface which is attached to a chilled water hydronic system and provides cooling into space mainly through radiation rather than convection. The infrared image of a radiant ceiling panel in a conditioned lab is shown in Fig. $3 \underline{4}$. It can be seen that temperature varies over the surface and it is colder in the areas which is in contact with water pipes. Based on ASHRAE guideline $[44][40]$, by assuming indoor air and average interior 
surfaces temperature of $27^{\circ} \mathrm{C}$, capacity of radiant panel ranges between 15 to $115 \mathrm{~W} / \mathrm{m}^{2}$ for water supply temperature of 15 to $25{ }^{\circ} \mathrm{C}$. For a combined radiant panel and natural air system in the tropical climate of Thailand, radiant panel capacity was found to be in the range of 30$40 \mathrm{~W} / \mathrm{m}^{2}$ with water supply temperature of $24-25{ }^{\circ} \mathrm{C}[16,45][15,41]$. In another study in the tropical climate of Singapore, Saber et al. [20] 193 concluded that from morning till afternoon under various supply water temperatures, radiant ceiling panel heat flux varies between 9 to 43

Formatted: Font: $12 \mathrm{pt}$ Formatted: Font: $10 \mathrm{pt}$ Formatted: Font: $12 \mathrm{pt}$ Formatted: Font: $10 \mathrm{pt}$ $\mathrm{W} / \mathrm{m}^{2}$.

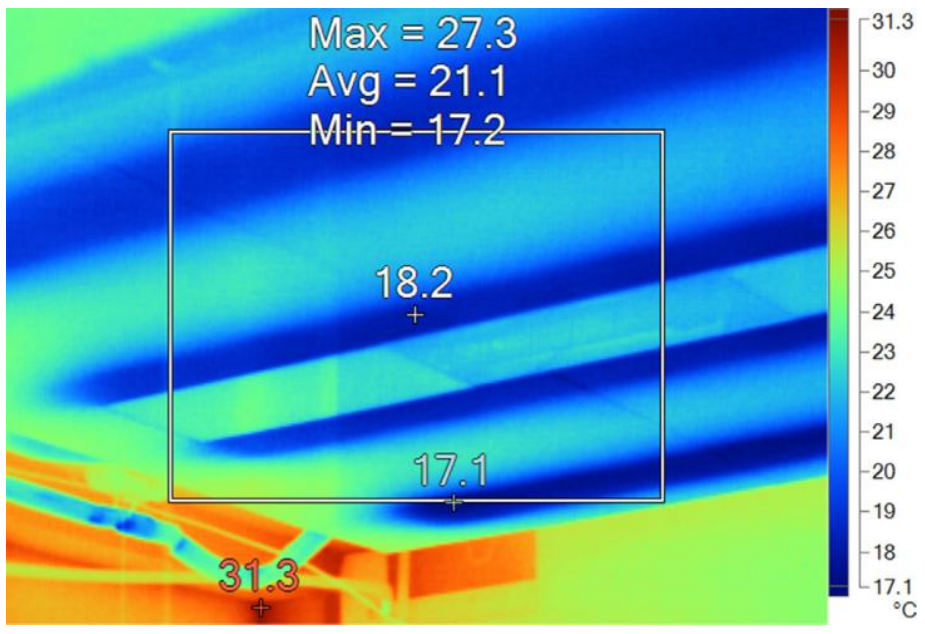

Fig. 3-4 Infrared image of a radiant cooling panel hung on ceiling [20][19]

In radiant slab cooling (RSC), water pipes are embedded into structure of building and it provides mostly radiant cooling from floor or ceiling. This system requires integration with building structure and needs to be planned at design stage before concrete pour (Fig. 45). RSC also employs thermal mass of structure in order to shift and reduce peak cooling load of building. Compared to radiant cooling panel, this design is more suitable for spaces where steady cooling is required for a length of time. RCP can adjust faster to change in cooling load and have better acoustical dampening as well as the option to be integrated with other building 
systems like lighting. International standard organization on building environmental design section provided guidelines for design, dimensioning, installation and control of embedded radiant cooling system into structure of building as thermally activated building systems (TABS) [46].

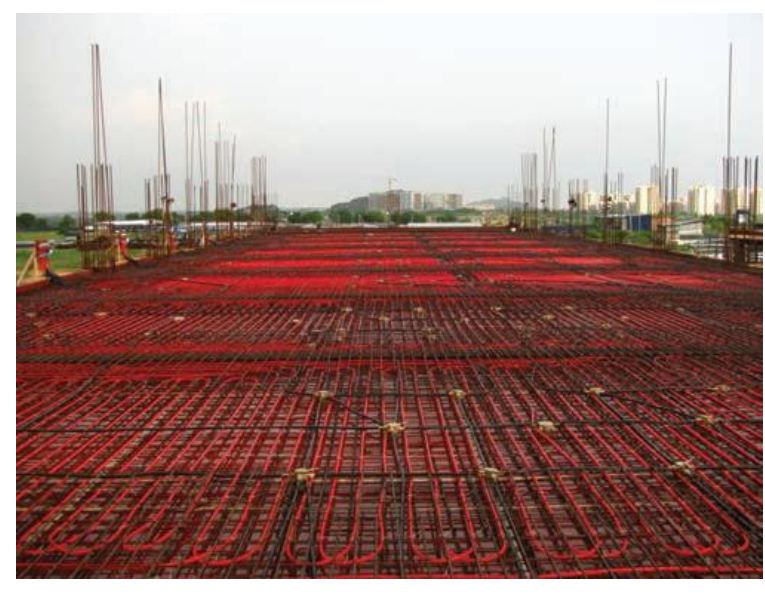

Fig. 4 $\underline{5}$ Water pipes in slab cooling system $\underline{[25][24]}$

Formatted: Font: $12 \mathrm{pt}$

Formatted: Font: $10 \mathrm{pt}$

High temperature cooling system can be implemented in buildings through convective based system of chilled beam in which chilled water passes through a heat exchanger located inside the conditioned space. Passive chilled beam is usually suspended on the ceiling and provides sensible cooling through convective heat transfer with surrounding air. Warm air adjacent to coils gets cooler and denser so it moves downward and causes a natural convection flow in the indoor space. The perforated metal casing in Fig. $5 \underline{6}$ is for providing comfortable cooling with aesthetic advantages and typically it has $50 \%$ open area. The implication of passive chilled beam has not been explicitly explored in the literature for the tropical context while it is known that PCB can provide fast response cooling and is suitable for spaces with high cooling load requirements [25][24]. 


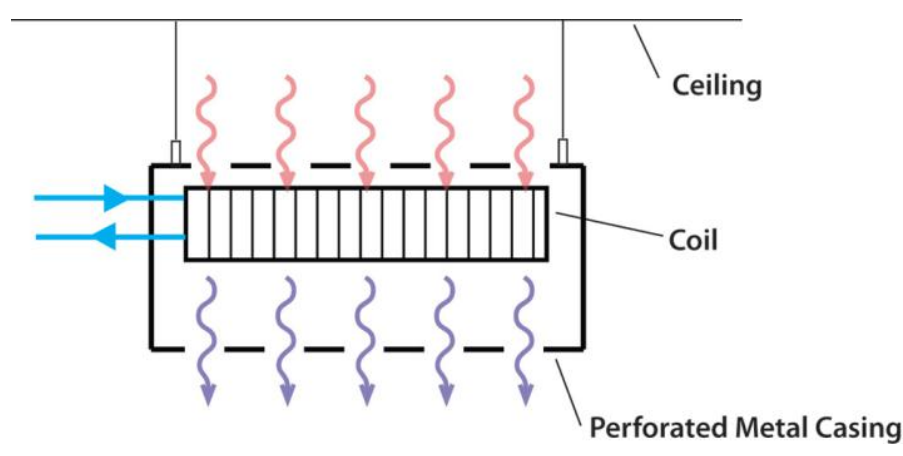

Fig. 5-6 A passive chilled beam in operation $[47][42]$
Formatted: Font: $12 \mathrm{pt}$

Formatted: Font: $10 \mathrm{pt}$

In high temperature cooling systems like RCP, RSC and PCB, water based and air based systems are operating independently in parallel. In active chilled beam design, conditioned air passes through heat exchanger to enhance heat transfer mechanism between air and pipes. The schematic of an operating active chilled beam is shown in Fig. $6 \underline{7}$. The primary ventilation air mixes with secondary room air to supply dehumidified and cool air into space. In the tropical context, the main design consideration for implementation of ACB is to avoid condensation on beam and maintain dry cooling in the units. Kosonen and Tan [15][14] investigated an implemented case of ACB in Singapore office building and concluded that condensation in Formatted: Font: $12 \mathrm{pt}$ Formatted: Font: $10 \mathrm{pt}$ ACB unit is possible to be avoided by minimizing infiltration, supplying sufficient conditioned air and adequate control of system. 


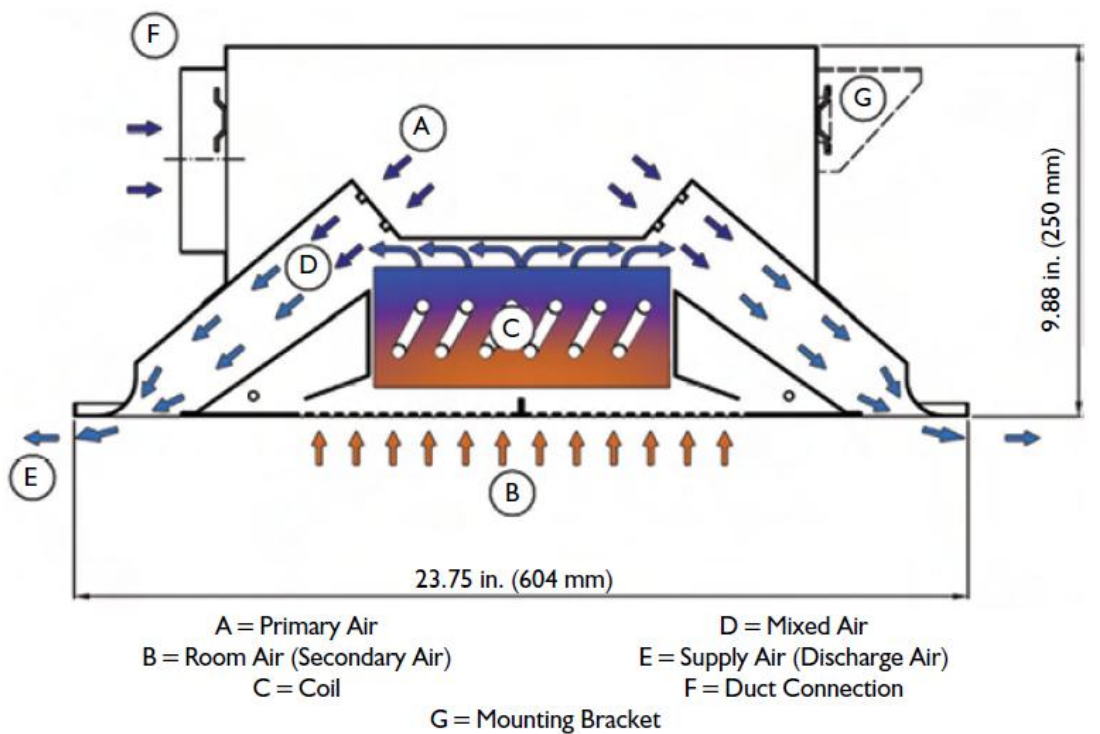

Fig. 67_ An active chilled beam in operation [48], $[43]$

An air based system is required to work in parallel to high temperature cooling device to handle latent load and ventilation requirement of indoor space. This air system could be a central DOAS-VAV, RAS-VAV design or even a decentralized DOAS or FCU located near the conditioned space. In the ideal operational scenario, air system design accommodates utilizing the most achievable cooling capacity from high temperature cooling system and it satisfies main part of space sensible load. In DOAS design, supply air is only limited to ventilation outdoor air and it can bring the opportunity to downsize AHU and reduce duct size and fan energy use compared to the all air system. Khan et al. [28],27] conducted energy simulation analysis for applications of radiant cooling system in the tropics and showed that radiant cooling combined with DOAS can provide $12.8 \%$ higher energy saving compared to RSC-FCU design. The coupled design of decentralized DOAS-RCP [22,49,50]\{21,41,15\} can bring chilled water closer to the indoor space by using small decentralized air supply units integrated into building structure and further cut the fan energy use. DOAS design suits spaces with air tight façades and low latent load where dehumidified fresh air could bring down
Formatted: Font: $12 \mathrm{pt}$

Formatted: Font: $10 \mathrm{pt}$
Formatted: Font: $12 \mathrm{pt}$

Formatted: Font: $10 \mathrm{pt}$ 
indoor dew point below HTC operational temperature. For spaces with high infiltration rate, reconditioning of return air (RA) in RAS design can result in a more efficient system rather than DOAS. If latent load of space including infiltration of humid outdoor air and human load could be handled by low volume supply air of DOAS, there would be no need to recondition indoor air.

The air distribution type in high temperature cooling applications also varies depending on types of HTC device and space cooling load characteristics. This could vary from mixing strategy like ceiling supply - ceiling exhaust to displacement oriented distribution types like DV or floor supply - ceiling exhaust. In the reported studies of HTC applications, air supply temperature ranged between 14 to $19{ }^{\circ} \mathrm{C}$ and ventilation rate was around 1 to $2 \mathrm{lit} / \mathrm{s} / \mathrm{m}^{2}$ or 5 to $10 \mathrm{lit} / \mathrm{s} /$ person based on $5 \mathrm{~m}^{2}$ per person occupancy rate. This level of ventilation is above the minimum ventilation requirement of Singapore standard SS 553 [51],46] which is 5.5 lit/s/person. The chosen range of supply temperature in this concept may not satisfy the local comfort criteria for distribution strategy of DV and FS-CE. A numerical study on the implementation of DDOAS-RCS under FS-CE distribution [52],477 concluded that with off coil air temperature of $14{ }^{\circ} \mathrm{C}$, in the areas close to floor diffusers, air could be around $17{ }^{\circ} \mathrm{C}$ which raises the concerns of cold feet for occupants seated there.

Dehumidification of ventilation air requires low temperature chilled water while HTC system is designed to operate with high temperature chilled water. The selection of design and control strategy for providing both LTCW and HTCW at the same time has an important impact on optimal operation and energy efficiency of the system. The typical strategy is to produce low temperature chilled water $\left(6^{\circ} \mathrm{C}\right)$ in central plants and employ three way control valves to raise the supply temperature for HTC. The schematic of water hydraulic lines and air ducts in a DOAS combined with radiant panel is shown in Fig. $7 \underline{8}$. The valve modulator $\left(\mathrm{V}_{2}\right)$ regulates the flow volume in mix of supply and return chilled water in pipes based on 
feedback from temperature sensors $\left(T_{3}\right.$ or $\left.T_{4}\right)$. Sastry and Rumsey [25],24] explored the efficiency and robustness of different control strategies and found that controlled valves based on fixed return water temperature perform the best. The second strategy is to keep chilled water loop of HTC and LTC separate and use a water to water heat exchanger to transfer the cooling to HTC loop. The schematic of a VAV-RCP with two separate hydronic system loops is shown in Fig. 89. The return water from AHU passes through a heat exchanger to provide a supply chilled water of $15{ }^{\circ} \mathrm{C}$ for radiant ceiling panel operation. This strategy has been implemented mostly in research labs to have a better control on operation of high temperature cooling device $[27,45], 26,41]$. The third strategy is to use two separate chillers and water hydronic loops for HTC and LTC systems as explained in Section 2.1 (Fig. Z3 3 ). This scheme has the potential to introduce further energy saving opportunities especially for the applications where more than one chiller has been designated for cooling of building.

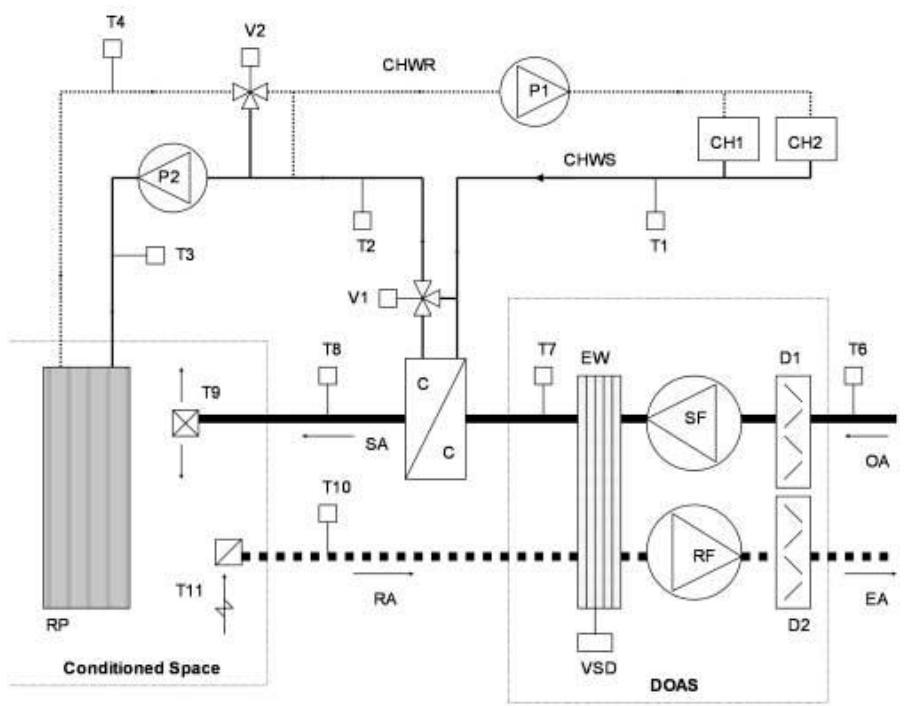

Fig. $7 \underline{8}$ Water hydronic lines and air streams in a DOAS combined with radiant panel [53][48] (SF: supply fan, RF: return fan, P 1-2: pumps, C/C: cooling coil, T 1-11: temperature sensors, D 1-2: Dampers, V 1-2: valve modulators, EW: Enthalpy wheel, RP: radiant panel, CH 1-2: chillers) 


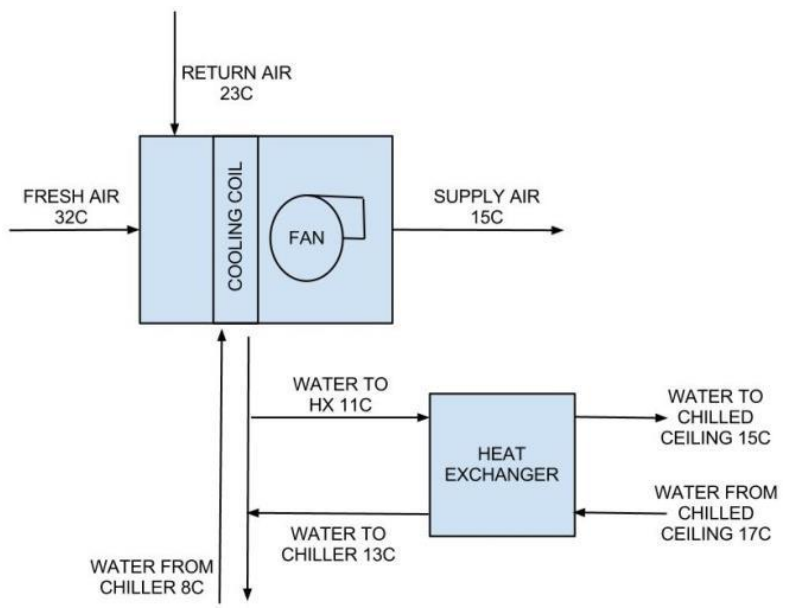

Fig. 8-9 Employing a heat exchanger to provide high temperature chilled water in a VAV-

$$
\text { RCP system [27][26] }
$$

Because of concerns regarding to condensation in tropical buildings, the start up and shut down strategy of HTC system needs to be well planned and followed. Kosonen and Tan [15][14] concluded that air based system needs to be switched on 30 minutes before water based system in the morning in order to get rid of stored humidity in the space over the night. Formatted: Font: $12 \mathrm{pt}$ Formatted: Font: $10 \mathrm{pt}$ This amount of time was estimated for a building with air tight façade and it could vary based on characteristics of building. It is also advisable to switch off HTC device before air based system to avoid any possible condensation after scheduled occupancy. In the case of slab cooling system implementation, energy saving concerns also comes into play in choosing the right start up and shut down strategy. Because of stored cooling capacity in slab due to thermal mass, it is required to operate the radiant system in a shifted schedule compared to occupancy schedule. One case study in the tropics recommended to switch on slab cooling system one to two hours before occupancy and to switch it off one to two hours before unoccupancy $[25]\{24]$. Khan et al. [28],27] also explored various control strategies for operation of slab cooling system in the tropical climate of Hyderabad in India and concluded that maximum energy

Formatted: Font: $12 \mathrm{pt}$ Formatted: Font: $10 \mathrm{pt}$ Formatted: Font: $12 \mathrm{pt}$ Formatted: Font: $10 \mathrm{pt}$ 
saving can be achieved when slab cooling system shut off four hours before end of occupancy schedule.

\subsection{Investment and maintenance costs}

Investment cost required for different HVAC systems is usually the key decision factor for selection of a design especially when building investors and users are two different parties. The cost of equipments and labors are geographic dependent and they also could vary based on market demand and scale of manufacturing. A study conducted side by side comparison of VAV and slab cooling system in the Hyderabad of India and concluded that capital cost of DOAS-RSC is slightly lower than VAV system [25][24]. The cost saving opportunities from reduction of AHU and duct size was about $6 \%$ of total cost of ACMV system while radiant piping, accessories and installation raised the investment cost for around $23 \%$. The study considered $33 \%$ reduction in HVAC low side work or commissioning cost in the case of radiant cooling. In another study, Mumma [4] compared the first cost of DOAS-Radiant panel with all air VAV system for a six storey building in the context of Philadelphia, in US. He showed that total cost benefits of radiant cooling system through reduction of AHU, ductwork and floor to floor height as well as integration with electrical and fire suppression services could outweigh the added cost of radiant panels. However, for the application of active chilled beams in the context of California in US, Stein and Taylor [54][499] estimated that total cost of DOAS-ACB system is about 2.5 times of VAVR design. They considered additional labor and subcontractors costs for ACB design and installation.

High temperature cooling concept is a new design for the tropical context and its practical implications have not been investigated explicitly for this climate. Having cooling coil and chilled water inside the conditioned space requires further inspection and possibly higher maintenance cost. In the case of active and passive chilled beam, a regular cooling coil 
cleaning service is required to avoid losing part of units' capacity over time because of collected dust on coils. The panel metal sheet and chilled water pipe behind the radiant cooling panel also may require regular cleaning service. In order to reduce the risk of condensation in applications of slab cooling system in the tropics, it was advised to insulate all water pipe connections and manifolds [25],224].

\section{Integration with energy recovery systems}

In applications of high temperature cooling system, DOAS as the parallel air based system can provide better performance and lower first cost opportunities compared to RAS due to reduction in the size of AHU, ducting and fan energy use. The enthalpy difference between the two air streams of fresh outdoor and indoor exhaust is significant and an energy recovery system can reduce part of ventilation cooling load. Different types of ERS devices have been introduced and investigated in the literature and industry. Rotary desiccant dehumidifier (RDD) is one of these designs which incorporates a rotary wheel with desiccant coated honeycombs for exchange of humidity. In active type of rotary desiccants (Fig. 910), a heat source is required to activate the regeneration air streams in order to enhance the mass transfer mechanism in the wheel. The warm and humid process air gets dehumidified after exchange of humidity with regeneration air and then it is supplied into indoor space. The required heat source is the main constraints for this design which is not easily accessible in the tropical climate. Alongside this design, there is passive type of rotary desiccant in which the wheel is placed between OA and EA streams and energy recovery happens without help of heat source. In the passive RDD applications, the wheel needs to rotate at much faster speed compared to active types [55][50]. 


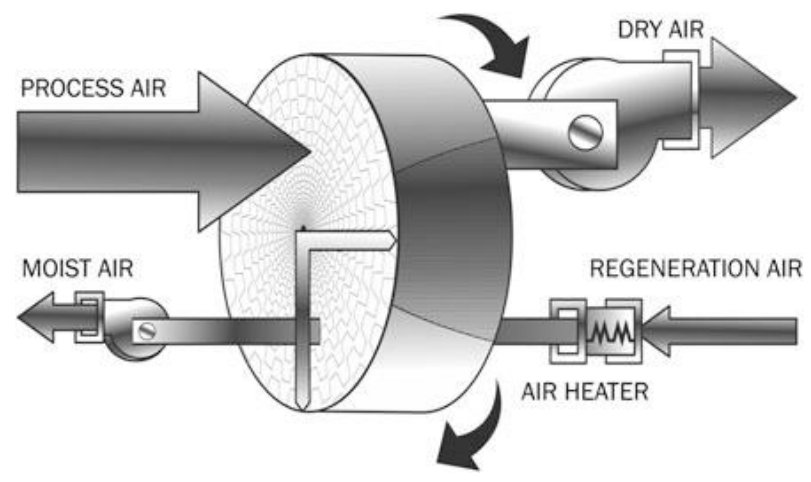

Fig. 9-10 Active type of rotary desiccant wheel with air heater [55][50]

Formatted: Font: $12 \mathrm{pt}$

Formatted: Font: $10 \mathrm{pt}$

Several studies in the literature tried to explore the application of high temperature cooling system combined with active rotary desiccant dehumidification in the tropics. Ameen and Khizir $[14][13]$ evaluated the performance of an active desiccant dehumidification system coupled with chilled ceiling in the tropical climate of Malaysia. They found that this Formatted: Font: $12 \mathrm{pt}$ Formatted: Font: $10 \mathrm{pt}$ combination has superior performance over conventional system in applications where high ventilation rate is required like in theatres and hospitals. In another study in Singapore, Wahed et al. $[18], 17]$ conducted energy simulation to investigate the performance of a thermally regenerated desiccant system integrated with chilled beam in the warm and humid climates. They modelled the active RDD with three different heating sources for regeneration process including electric heater, solar collector and waste heat. The annual energy simulation and economic analysis revealed that solar assisted dehumidifier integrated with active chilled beam is the most cost effective design which consumes 10-20\% less energy than conventional VAV system in the tropics.

Membrane based air to air heat exchanger is another type of energy recovery systems which is getting wide range applications in the industry. In this design, heat and humidity transfers between two air streams happen at a porous membrane surface without any active parts inside the device. Air streams inside the heat exchanger can interact in different 
arrangements as parallel, counterflow or cross flow streams [56],[51]. During this interaction, outside air loses some level of its heat and humidity to dry and cool exhaust air leaving the indoor space. Nasif et al. [57],52\} evaluated the performance of a $\mathrm{Z}$ type parallel plate heat exchanger (Fig. 1011) made of porous membrane. In this $\mathrm{Z}$ type design configuration, three arrangement scenarios of parallel flow, counter flow and cross flow happen between two air streams inside the heat exchanger. The results of experiments and annual energy simulations showed that implementing this enthalpy heat exchanger in air conditioning system can result in 5.7 to $9 \%$ energy saving for the tropical climate of Kuala Lumpur.

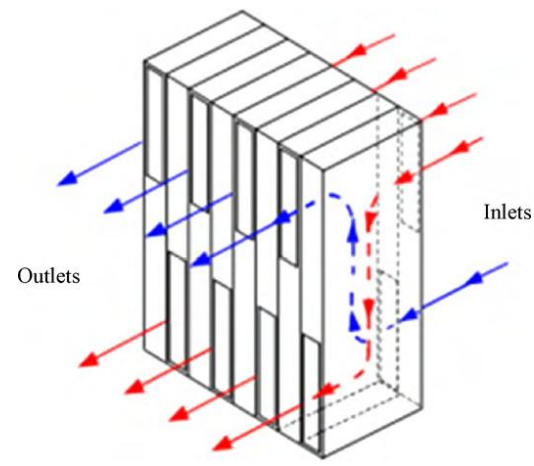

Fig. 10-11 "Z" type membrane based heat exchanger [57][52]

\section{Direct connection to cooling tower}

Incorporating high temperature cooling systems in building could bring the opportunity to implement passive chilled water systems like cooling tower to provide the required HTCW without use of refrigeration system. Outdoor wet bulb temperature is the key parameter for this design which usually ranges between 25 to $26{ }^{\circ} \mathrm{C}$ in the tropics except in the dry season for the tropical savanna climate. Cooling tower can provide chilled water in the range of 25 to $26^{\circ} \mathrm{C}$ for the radiant cooling system. However, this level of chilled water temperature cannot
Formatted: Font: $12 \mathrm{pt}$

Formatted: Font: $10 \mathrm{pt}$

Formatted: Font: $12 \mathrm{pt}$

Formatted: Font: $10 \mathrm{pt}$

Formatted: Font: $12 \mathrm{pt}$

Formatted: Font: $10 \mathrm{pt}$ 
provide effective cooling in HTC device for day time applications in office spaces. Vangtook and chirarartaran [17],[16] investigated different operational and design scenarios for the application of cooling tower to provide high temperature chilled water for radiant cooling panel in Thailand. The results showed that this system can provide adequate indoor condition for spaces with low heat gain in night time applications. Tantiwichien and Taweekun [24],223] also investigated the performance of radiant cooling panel using chilled water from an employed cooling tower in the tropical climate of Thailand through experiments and simulations. The results showed that this design is able to provide comfortable indoor condition during night time and early morning with $41 \%$ energy saving compared to split-type air conditioner. The performance of incorporated cooling tower in this design was around 60 $\%$ which varied depending on outdoor dry bulb and wet bulb temperatures.

\section{Discussions}

The whole idea behind implementing high temperature cooling systems in buildings is to introduce a more energy efficient cooling system compared to the conventional all air system. A precise and detailed design strategy needs to be followed in order to truly utilize the potential benefits of HTC systems. It was shown by several studies in the literature $\llbracket 17,28][16,27]$ that fan energy use can be reduced by 50 to $70 \%$ through incorporating DOAS combined with radiant cooling system. Downsizing fan and duct size in ACMV system compared to conventional design is the key factor for achieving higher energy saving in this concept. Providing an air tight façade for the indoor space is necessary to minimize the infiltration rate and latent load of space, =especially in the tropical context where outdoor humidity is high all year round. In the ideal operational scenario, the amount of supply air volume is in the range of minimum ventilation requirement of space and HTC plays a significant role in satisfying the sensible load of space. 
HTC systems requires-operate with high temperature chilled water which can bring the potential to enhance the operational efficiency of chiller in buildings. Two separate chillers need-could to be installed in buildings to provide LTCW and HTCW for air and water systems, respectively. This design strategy suits the buildings where multiple chillers were assigned to be operational. The potential energy saving of this separation can be understood from the reverse theoretical thermodynamic cycle of Carnot. This cycle is the most efficient possible set of processes to transfer a certain amount of heat from a cold source $\left(\mathrm{Q}_{\mathrm{C}}-\mathrm{T}_{\mathrm{C}}\right)$ to a hot one $\left(\mathrm{Q}_{\mathrm{H}^{-}} \mathrm{T}_{\mathrm{H}}\right)$ with a given amount of usable work $(\mathrm{W})$. The COP of the cycle in the tropical context (average outdoor temperature of $30^{\circ} \mathrm{C}$ ) for the low temperature $\left(6^{\circ} \mathrm{C}\right.$ ) and high temperature $\left(16^{\circ} \mathrm{C}\right)$ cooling operations can be determined as follows,

$\operatorname{COP}_{\text {Cooling }}=\frac{Q_{C}}{W}=\frac{Q_{C}}{Q_{H}-Q_{C}}=\frac{T_{C}}{T_{H}-T_{C}} \quad$ Eq.1

$\operatorname{COP}_{\text {Carnot, low temperature }}=\frac{T_{c}}{T_{h}-T_{c}}=\frac{273.15+6}{30-6}=11.6 \quad$ Eq. 2

$\operatorname{COP}_{\text {Carnot, high temperature }}=\frac{T_{c}}{T_{h}-T_{c}}=\frac{273.15+16}{30-16}=20.6 \quad$ Eq. 3

Based on the reverse theoretical Carnot cycle, there is a $77 \%$ (Eq. 2-3) increase in operational COP of chillers for high temperature cooling applications in tropical buildings. However, because of the exergy losses in different sub-processes inside the chiller, the COP of actual refrigeration systems operating in cooling system of buildings are far below the theoretical Carnot values. The level of increase in COP for high temperature condition compared to low temperature cooling scenario is also less likely to be in the same order. The chillers in building cooling system are usually designed and regulated to efficiently provide chilled water at temperature of $6-7^{\circ} \mathrm{C}$ which matches the requirement of conventional air 
conditioning system in the buildings. Custom designed chillers for low temperature lift conditions have been introduced and investigated by some research institutes and manufacturing companies for high temperature cooling applications or other process cooling requirements. Doyon [34], 30$]$ investigated the critical design parameters of centrifugal chillers for superior efficiency at low temperature lift conditions. He found open-drive/gear-drive compressors with variable orifice and oil education system as the most suitable features in chillers for high temperature cooling applications. He also concluded that chillers with hermetic drive motors would not be able to utilize the potential energy saving of HTC operational conditions due to required high head pressure for cooling of motor windings. In another investigation, Wyssen et al. [58],53] designed a chiller prototype for low temperature lift conditions which was equipped with a semi-hermetic reciprocating compressor. The outcomes of experiments showed that at evaporative temperature of $15{ }^{\circ} \mathrm{C}$, the $\mathrm{COP}$ of this chiller increases from 4 at $40{ }^{\circ} \mathrm{C}$ temperature lift to about 11.4 at $13{ }^{\circ} \mathrm{C}$ lift. The $\mathrm{COP}$ of this custom designed chiller as well as ideal Carnot and typical chillers are plotted in Fig. 12. It can be seen that performance curve of this prototype chiller fits in between typical chillers and ideal efficiency curves. The low lift chiller performs better than air cooled/water cooled chillers both in terms of COP value at any specific lift and increase rate for lower temperature lift. This shows some part of exergy losses in chiller sub-processes has been eliminated in this design. The COP of this custom designed chiller as well as ideal Carnot and a regular chiller are plotted in Fig. 11. It can be seen that the performance curve of this prototype chiller fits in between regular chiller and ideal efficiency curves. The low lift chiller performs better than regular chiller both in terms of COP value at any specific lift and increase rate for lower temperature lift. This-shows some part of exergy losses in the chiller sub processes has been eliminated. 


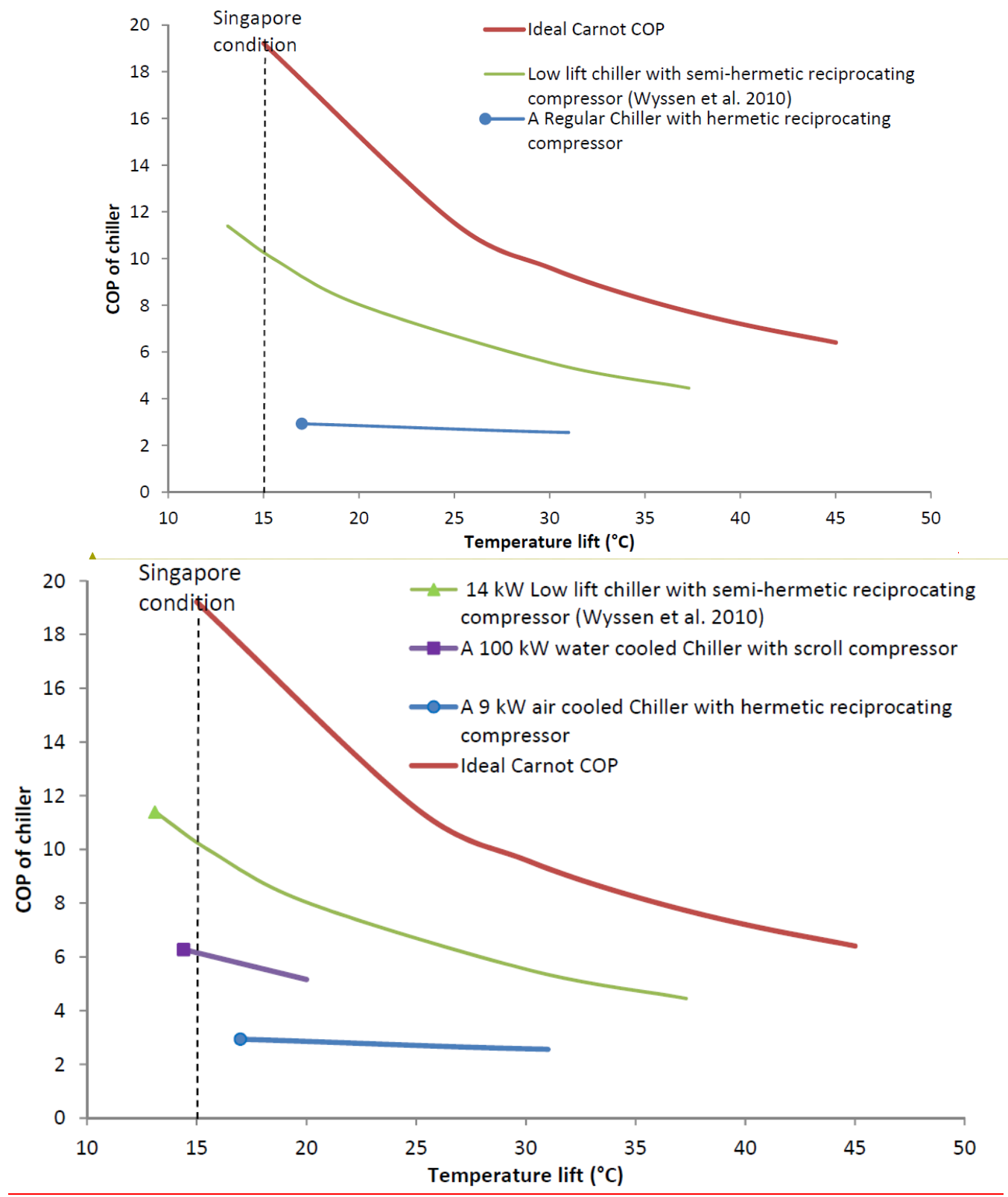

Formatted: Font: (Default) +Heading CS, 12 pt

Fig. 11-12 COP of ideal Carnot cycle, low lift chiller and two typical air cooled/water cooled chillers a regular chiller at evaporative temperature of $15^{\circ} \mathrm{C}$

The application of high temperature cooling in tropical buildings can be categorized based on their supply chilled water temperature to HTC device. When the supply water temperature 
is above the outdoor dew point level and in the range of 25 to $26{ }^{\circ} \mathrm{C}$, it can only provide comfortable indoor space for night time applications. This design scheme could also be used during day time in office buildings with low space heat gain for occupants under light clothing level when personalized or ceiling fans are used to raise the air movement on work stations. In the second design scheme, chilled water is supplied to HTC at temperatures lower than outdoor dew point and comfortable indoor space can be achievable under any indoor/outdoor scenarios. In this scheme, the parallel conditioned air system would keep the indoor dew point below HTC operating temperature to avoid condensation. The only reported deficiency in the literature for this conditioned indoor space is the low air movement as locally acclimatized occupants in the tropics prefer to be exposed to higher air speed. This issue has been resolved by using a ceiling fan in the office space for an implemented case of radiant cooling system [25],24].

Different strategies have been investigated and suggested in the literature for the design and operation of HTC in tropical buildings. A detailed control strategy is required to be followed especially in the cases where HTC operational temperature is below outdoor dew point to avoid condensation. The start up and shut down schemes could vary based on type of HTC system and characteristics of buildings. In the case of slab cooling system, a shift needs to be considered between operational schedule of HTC and occupancy period. For other types of HTC systems located in the indoor space, the air based system should be switched on /off before/-and-after water based system in the morning and evening, respectively. The choice of air conditioning and distribution system could also play an important role in energy saving and thermal comfort of occupants. DOAS was found to be the best parallel air based system where and from energy efficiency point of view, the amount of supply air is best to be kept near minimum ventilation requirements of space. In spaces with high latent load, supply air volume to space may be required to exceed this minimum requirement. Since, in this design scenario, 
the off coil temperature would be in the range of 14 to $16{ }^{\circ} \mathrm{C}$, it is advisable to implement ceiling supply-ceiling exhaust distribution instead of displacement strategy to avoid cold feet for occupants.

The initial cost of high temperature cooling system varies based on HTC device types and radiant slab cooling is the least costly choice. However, this design needs to be planned at early stages before construction of building structure. The added cost of piping and accessories to overall ACMV design could be mitigated by reduction of fan and duct size for circulation of air in buildings. Less floor to floor height and integration with lighting and fire suppression systems are other potential opportunities for saving material and space per floor area. In order to utilize these potential benefits for implementation of high temperature cooling system, the coordination of building structural, mechanical, electrical and fire protection contractors is required. The maintenance cost of HTC system is also expected to be higher due to significantly higher water pipes compared to conventional all air system especially in the case of passive/active chilled beams.

The advantages of water based system combined with DOAS can be further utilized if an energy recovery system is incorporated into air handling unit. The high enthalpy difference between outdoor and indoor air in the tropics makes implementation of ERS more economically feasible. Several studies in the literature reported significant energy saving for coupling of HTC and active rotary desiccant dehumidification in the tropics through experimental setup or simulation. Solar assisted heating was found as the best strategy for the required heating in the regeneration process, although this source is not reliable in the tropics due to high annual median cloud cover. Membrane heat exchangers (MHX) have also been explored in the literature in the tropical context and promising performance was observed for this design [50]. 
A collection of high temperature cooling design strategies and components in tropical building based on reported outcomes in the literature iswas selected as shown in Fig. $12 \underline{13}$. User controlled temperature and humidity sensors are considered in indoor space to provide necessary changes on operation of water and air based systems based on different indoor/outdoor scenarios. User controlled temperature and humidity sensors were considered in the indoor space to have separate feedback control on both water and air based systems. With increase of humidity or dew point temperature above the specified threshold, signal would be sent to actuators on air supply units' pumps and three way control valve to reduce water supply temperature and/or increase water flow rate. This change would enhance dehumidification capacity of air system to avoid any risk of condensation on radiant panel. Three way control valve and pump on HTC hydronic system could modulate its capacity based on feedback from temperature sensors to provide the required sensible cooling for space. Installing $\mathrm{CO}_{2} \underline{\text { sensors can also bring further value to this design for the thermal zones }}$ where there is high variation of occupancy level like in meeting rooms. Based on these sensors' feedback, the volume of fresh air coming into space could be regulated through modulating supply air fan speed. With increase of humidity or dew point temperature above the set threshold, damper in air duct gets more open to bring more dehumidified fresh air into conditioned space. The three way control valve on HTC hydronic system modulates its eapacity based on the feedback from temperature sensors to provide enough sensible cooling.

In this design strategy (Fig. 13), anAn energy recovery system was is also designated for DOAS to recuperate some part of cooling from exhaust air stream. This ERS device could be an active/passive desiccant wheel or a membrane based air to air heat exchanger which transfers heat and humidity between two air streams. The high enthalpy difference between indoor and outdoor condition in the tropical context would make ERS an effective system for

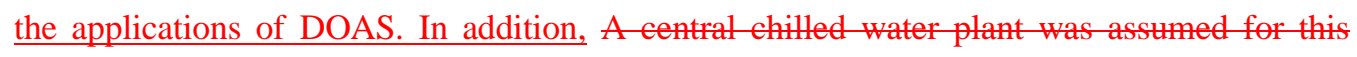


design scenario and three way control valves were designated to provide the adequate chilled water temperature for air based and water based systems. Tthe required high temperature chilled water for HTC can be provided through alternative strategies like cooling tower or a separate low lift chiller. Direct connection of HTC to cooling tower without refrigeration system is mostly suitable for spaces with low heat gain in night time applications. A custom designed chiller which operates at considerably higher efficiency in low temperature lift applications can also be a more efficient solution compared to a central low temperature chilled water (LTCW) system. The level of improvement in COP of designated low lift chiller needs to outweigh the added cost of having a separate chiller for HTC, in order for this alternative solution to be economically competitive 


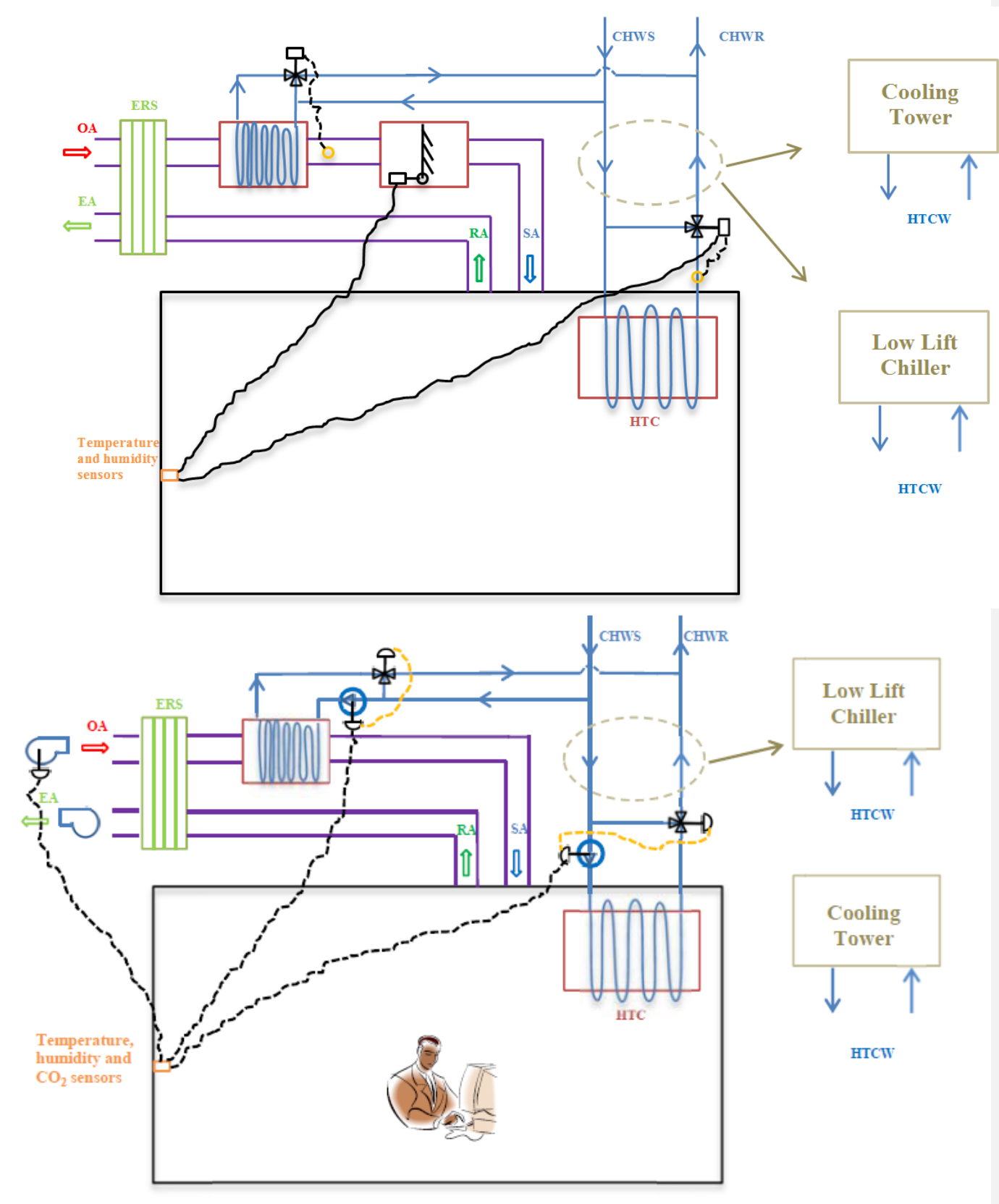

Fig. $12 \underline{13}$ The - A selected design strategies and components for the application of high temperature cooling in the tropics

\section{Conclusions}


The reported studies in the literature on the implementation of high temperature cooling systems in the tropics were reviewed to get a better understanding on overall performance of this cooling strategy for the warm and humid climates. Various aspects of this implementation were explored in terms of energy saving and thermal comfort for locally acclimatized occupants as well as optimal design and operational scenarios. The outcomes of this investigation can be summarized in the following points,

- HTC systems can bring the opportunity to downsize fan and duct size for air circulation and cut the fan energy use by half compared to all air system

- In the tropical context, aAn air tight façade is preferable for this strategy to minimize the infiltration rate or in other words the latent load of space

- Incorporating a custom designed chiller for low temperature lift conditions can further utilize the potential energy saving of this concept

- When supply chilled water temperature to HTC is above the outdoor dew point level, comfortable indoor condition can be achieved only under specific indoor/outdoor conditions. This high temperature water can be provided with direct connection to cooling tower without use of refrigeration system in the tropics.

- When supply chilled water temperature to HTC is below the outdoor dew point level, comfortable condition is achievable under any indoor/outdoor conditions. Although a parallel conditioned air system is required to avoid condensation on HTC device. The low air movement in this indoor space was the only reported comfort concern for locally acclimatized occupants in the tropics.

- A control strategy needs to be followed to avoid condensation in start up and shut down period of system in tropical buildings. In the case of slab cooling system, a 
shift between operational schedule of HTC and occupancy period needs to be considered.

- DOAS with ceiling supply-ceiling exhaust was found as the most suitable and efficient air conditioning and distribution strategy for HTC implementation.

- Among HTC cooling systems, slab cooling can be implemented at lower initial cost. However, it requires early-stage planning and integration into structure of building.

- Incorporation of energy recovery system into DOAS can reduce ventilation cooling load of space and improve the overall performance of HTC design. Membrane based air to air heat exchangers showed promising performance in the tropical context.

The practical implications of high temperature cooling system are required to be further explored through actual implementation of this concept into tropical buildings. This coupled air/water system demands a more sophisticated design and control strategy compared to all air system. Thoughtful decisions need to be made at design stage based on experience of past projects and building performance simulation for a successful implementation of high temperature cooling strategy in the tropics.

\section{Acknowledgment}

This work was established at the Singapore-ETH Centre for Global Environmental Sustainability (SEC), co-funded by the Singapore National Research Foundation (NRF) and ETH Zurich in collaboration with department of building of NUS. 


\section{References}

[1] NEA, Singapore's Second National Communication: Under the United Nations Framework Convention on Climate Change, National Environmental Agency, 2010.

[2] A. Novoselac, J. Srebric, A critical review on the performance and design of combined cooled ceiling and displacement ventilation systems, Energy Build. 34 (2002) 497-509. doi:10.1016/S0378-7788(01)001347.

[3] Z. Tian, J.A. Love, Application of radiant cooling in different climates: assessment of office buildings through simulation, in: Elev. Int. IBPSA Conf., 2009.

http://www.ibpsa.org/proceedings/BS2009/BS09_2220_2227.pdf (accessed August 21, 2013).

[4] S.A. Mumma, Chilled Ceilings in Parallel with Dedicated Outdoor Air Systems: Addressing the Concerns of Condensation, Capacity, and Cost, ASHRAE Trans. 108 (2002).

[5] S.A. Mumma, Condensation issues with radiant cooling panels, IAQ Appl. 2001. (2001) 16-18.

[6] E.M. Saber, M. Mast, K.W. Tham, H. Leibundgut, Ventilation effectiveness and contaminant distribution in an occupied space conditioned with low exergy ventilation technologies in the tropics, in: Eindhoven, Netherlands, 2015

[7] W.-H. Chiang, C.-Y. Wang, J.-S. Huang, Evaluation of cooling ceiling and mechanical ventilation systems on thermal comfort using CFD study in an office for subtropical region, Build. Environ. 48 (2012) 113-127. doi:10.1016/j.buildenv.2011.09.002.

[8] W. Wang, Z. Tian, Indoor thermal comfort research on the hybrid system of radiant cooling and dedicated outdoor air system, Front. Energy. 7 (2013) 155-160. doi:10.1007/s11708-013-0244-z.

[9] S. Schiavon, F. Bauman, B. Tully, J. Rimmer, Room air stratification in combined chilled ceiling and displacement ventilation systems, HVACR Res. 18 (2012) 147-159. doi:10.1080/10789669.2011.592105. [10] B.W. Olesen, Radiant Floor Cooling Systems, ASHRAE J. 50 (2008) 16-22.

111] J. (Dove) Feng, S. Schiavon, F. Bauman, Cooling load differences between radiant and air systems, Energy Build. 65 (2013) 310-321. doi:10.1016/j.enbuild.2013.06.009.

[12] M.C. Peel, B.L. Finlayson, T.A. McMahon, Updated world map of the Köppen-Geiger climate classification, Hydrol Earth Syst Sci. 11 (2007) 1633-1644. doi:10.5194/hess-11-1633-2007.

[13] WeatherSpark, Weather Graphs and Maps - WeatherSpark, (n.d.). https://weatherspark.com/ (accessed November 24, 2015).

14] A. Ameen, K. Mahmud, Desiccant Dehumidification with Hydronic Radiant Cooling System for AirConditioning Applications in Humid Tropical Climates, ASHRAE Trans. 111 (2005) 225-237.

[15] R. Kosonen, F. Tan, A feasibility study of a ventilated beam system in the hot and humid climate: a casestudy approach, Build. Environ. 40 (2005) 1164-1173. doi:10.1016/j.buildenv.2004.11.006.

[16] P. Vangtook, S. Chirarattananon, An experimental investigation of application of radiant cooling in hot humid climate, Energy Build. 38 (2006) 273-285. doi:10.1016/j.enbuild.2005.06.022.

[17] P. Vangtook, S. Chirarattananon, Application of radiant cooling as a passive cooling option in hot humid climate, Build. Environ. 42 (2007) 543-556. doi:10.1016/j.buildenv.2005.09.014.

[18] M.A. Wahed, Y.W. Wong, K.C. Toh, H.K. Ho, Performance Analysis of Thermally Regenerated Desiccant System Integrated With Chilled Beam for Warm Humid Climate, in: ASME 2010 Int. Mech. Eng. Congr. Expo., 2010: pp. 1375-1382. doi:10.1115/IMECE2010-40263.

[19] A.S. Binghooth, Z.A. Zainal, Performance of desiccant dehumidification with hydronic radiant cooling system in hot humid climates, Energy Build. 51 (2012) 1-5. doi:10.1016/j.enbuild.2012.01.031.

[20] E.M. Saber, R. Iyengar, M. Mast, F. Meggers, K.W. Tham, H. Leibundgut, Thermal comfort and IAQ analysis of a decentralized DOAS system coupled with radiant cooling for the tropics, Build. Environ. 82 (2014) 361-370. doi:10.1016/j.buildenv.2014.09.001.

[21] F. Meggers, J. Pantelic, L. Baldini, E.M. Saber, M.K. Kim, Evaluating and adapting low exergy systems with decentralized ventilation for tropical climates, Energy Build. 67 (2013) 559-567. doi:10.1016/j.enbuild.2013.08.015.

[22] R.S. Iyengar, E. Saber, F. Meggers, H. Leibundgut, The feasibility of performing high-temperature radiant cooling in tropical buildings when coupled with a decentralized ventilation system, HVACR Res. 19

(2013) 992-1000. doi:10.1080/10789669.2013.826065.

[23] Y.H. Yau, S. Hasbi, Field analysis of indoor air quality in high rise and low rise green offices with radiant slab cooling systems in Malaysia, Indoor Built Environ. (2013) 1420326X13506130. doi:10.1177/1420326X13506130.

[24] A.-U.-W. Tantiwichien, J. Taweekun, An Experimental and Simulated Study on Thermal Comfort, IACSIT Int. J. Eng. Technol. 5 (2013) 177-180.

[25] G. Sastry, P. Rumsey, VAV vs. Radiant Side-by-Side Comparison, ASHRAE J. 56 (2014) 16-24.
Formatted: Bibliography,

Widow/Orphan control, Adjust space

between Latin and Asian text, Adjust space between Asian text and numbers 
[26] N. Nutprasert, P. Chaiwiwatworakul, Radiant Cooling with Dehumidified Air Ventilation for Thermal Comfort in Buildings in Tropical Climate, Energy Procedia. 52 (2014) 250-259.

doi:10.1016/j.egypro.2014.07.076.

[27] B. Seshadri, M.B.H. Sapar, Z. Jian, M. Neth, B. Wu, D. Ng, Feasibility Study of Chilled Ceiling Technology in Singapore through Simulation and Verification, in: Build. Simul. Optim. Conf., London, 2014.

https://www.academia.edu/7511381/Feasibility_Study_of_Chilled_Ceiling_Technology_in_Singapore_th rough_Simulation_and_Verification (accessed June 9, 2015).

[28] Y. Khan, V.R. Khare, J. Mathur, M. Bhandari, Performance evaluation of radiant cooling system integrated with air system under different operational strategies, Energy Build. 97 (2015) 118-128. doi:10.1016/j.enbuild.2015.03.030.

[29] M. Bruelisauer, K. Chen, R. Iyengar, H. Leibundgut, C. Li, M. Li, Mast M, Meggers F, Miller C, Dino R, Saber EM, Schlueter A, Tham KW., BubbleZERO - Design, Construction and Operation of a Transportable Research Laboratory for Low Exergy Building System Evaluation in the Tropics, Energies. 6 (2013) 4551-4571. doi:10.3390/en6094551.

[30] E. Saber, F. Meggers, R. Iyengar, The potential of low exergy building systems in the tropics - Prototype evaluation from the BubbleZERO in Singapore, in: Proc. Clima 2013 Energy Effic. Smart Healthy Build., Prague, Czech Republic, 2013.

[31] IEA ECBCS Annex 28, Low Energy Cooling Systems, UK, Coventry, 2000.

[32] IEA ECBCS Annex 37, Low Exergy Systems for Heating and Cooling Buildings - Guidebook, VTT Technical Research Centre of Finland, 2003.

[33] IEA ECBCS Annex 49, Low Exergy Systems for High-Performance Buildings and Communities, Frauenhofer Institute for Building Physics, 2010. http://www.annex49.com.

[34] T. Doyon, Chiller Design For Low-Lift Conditions, Air Cond. Heat. Refrig. News. 234 (2008) 13-15.

[35] M. Indraganti, R. Ooka, H.B. Rijal, G.S. Brager, Adaptive model of thermal comfort for offices in hot and humid climates of India, Build. Environ. 74 (2014) 39-53. doi:10.1016/j.buildenv.2014.01.002.

[36] H.C. Willem, K.W. Tham, Associations between thermal perception and physiological indicators under moderate thermal stress, in: 6th Int. Conf. Indoor Air Qual. Vent. Energy Conserv. Build. Sustain. Built Environ., 2007. http://scholarbank.nus.edu.sg/handle/10635/45914 (accessed June 16, 2014).

[37] N. Gong, K.W. Tham, A.K. Melikov, D.P. Wyon, S.C. Sekhar, K.W. Cheong, The Acceptable Air Velocity Range for Local Air Movement in The Tropics, HVACR Res. 12 (2006) 1065-1076. doi:10.1080/10789669.2006.10391451.

[38] W.A. Andreasi, R. Lamberts, C. Cândido, Thermal acceptability assessment in buildings located in hot and humid regions in Brazil, Build. Environ. 45 (2010) 1225-1232. doi:10.1016/j.buildenv.2009.11.005. [39] ASHRAE 55, ANSI/ASHRAE Standard 55-2004: Thermal Environmental Conditions for Human Occupancy, American Society of Heating, Refrigerating and Air-Conditioning Engineers, Atlanta, GA, 2004.

[40] International Standard, ISO 7730:2005 Ergonomics of the thermal environment -- Analytical determination and interpretation of thermal comfort using calculation of the PMV and PPD indices and local thermal comfort criteria, ISO 2005, Geneva, Switzerland, 2005.

[41] SS 554, SS 554:2009, Code of practice for indoor air quality for air-conditioned buildings, SPRING Singapore, Singapore, 2009.

[42] MS 1525, Code of Practice on Energy Efficiency and Use of Renewable Energy for Non-Residential Buildings, Department of Standards Malaysia, Putrajaya, Malaysia., 2007.

[43] Q.J. Kwong, M.A. Arsad, N.M. Adam, Evaluation of Indoor Thermal Environment in a Radiant-CooledFloor Office Building in Malaysia, Appl. Mech. Mater. 564 (2014) 228-233. doi:10.4028/www.scientific.net/AMM.564.228.

[44] R. and A.-C.E. American Society of Heating, 2012 ASHRAE Handbook--HVAC Systems and Equipment: AIR-CONDITIONING AND HEATING SYSTEMS, Chap. 6, Panel Heating and Cooling, (2012).

[45] S. Wongkee, S. Chirarattananon, P. Chaiwiwatworakul, A Field Study of Experimental of Radiant Cooling for Residential Building in a Tropical Climate, Jounal Autom. Control Eng. 2 (2014) 67-70.

[46] ISO 11855-3, Building environment design -- Design, dimensioning, installation and control of embedded radiant heating and cooling systems -- Part 3: Design and dimensioning, International Standard Organization, 2012

[47] P. Rumsey, J. Weale, Chilled Beams in Labs Eliminating Reheat \& Saving Energy on a Budget, ASHRAE J. 49 (2007).

[48] D. Alexander, M. O’Rourke, Design Considerations For Active Chilled Beams, ASHRAE J. (2008) 50$\underline{58 .}$ 
[49] M.K. Kim, H. Leibundgut, Evaluation of the humidity performance of a novel radiant cooling system connected with an Airbox convector as a low exergy system adapted to hot and humid climates, Energy Build. 84 (2014) 224-232. doi:10.1016/j.enbuild.2014.08.005.

[50] M.K. Kim, H. Leibundgut, A case study on feasible performance of a system combining an airbox convector with a radiant panel for tropical climates, Build. Environ. 82 (2014) 687-692. doi:10.1016/j.buildenv.2014.10.012.

[51] SS 553, SS 553:2009, Code of practice for air-conditioning and mechanical ventilation in buildings, SPRING Singapore, Singapore, 2009.

$52]$ E. Saber, M. Mast, K.W. Tham, H. Leibundgut, Numerical Modelling of an Indoor Space Conditioned with Low Exergy Cooling Technologies in the Tropics, in: 13th Int. Conf. Indoor Air Qual. Clim., Hong Kong, 2014.

[53] J.-W. Jeong, S.A. Mumma, W.P. Bahnfleth, Energy conservation benefits of a dedicated outdoor air system with parallel sensible cooling by ceiling radiant panels, ASHRAE Trans. 109 (2003) 627-636.

54] J. Stein, S.T. Taylor, VAV Reheat Versus Active Chilled Beams \& DOAS, ASHRAE J. (2013) 18-32.

[55] C.E.L. Nóbrega, N.C.L. Brum, An Introduction to Solid Desiccant Cooling Technology, in: C.E.L.

Nóbrega, N.C.L. Brum (Eds.), Desiccant-Assist. Cool., Springer London, 2014: pp. 1-23.

http://link.springer.com.libproxy1.nus.edu.sg/chapter/10.1007/978-1-4471-5565-2_1 (accessed July 30, 2015).

[56] ASHRAE, Ashrae Handbook: HVAC Systems and Equipment, 2000.

[57] M. Nasif, R. AL-Waked, G. Morrison, M. Behnia, Membrane heat exchanger in HVAC energy recovery systems, systems energy analysis, Energy Build. 42 (2010) 1833-1840. doi:10.1016/i.enbuild.2010.05.020.

[58] I. Wyssen, L. Gasser, B. Wellig, M. Meier, Chiller with small temperature lift for efficient building cooling, in: Proc Clima, Antalya, Turkey, 2010.

[1] NEA. Singapere's Second National Communication: Under the United Nations Framework Convention en Climate Change. National Envirenmental Ageney; 2010.

[2] Novoselac A, Srebric J. A critical review on the performance and design of combined cooled ceiling and displacement ventilation systems. Energy Build 2002;34:497 509. doi:10.1016/S0378-7788(01)00134-7.

[3] Tian Z, Love JA. Applieation of radiant cooling in different climates: assessment of office buildings through simmation. Elev. Int. IBPSA Conf., 2009.

[4] Mumma SA. Chilled Ceilings in Parallel with Dedicated Outdoor Air Systems: Addressing the Concerns ef Condensation, Capacity, and Cost. ASHRAE Trans 2002;108.

[5] Mumma SA. Condensation issues with radiant cooling panels. IAQ Appl 2001 2001:16-8.

[6] Saber EM, Mast M, Tham KW, Leibundgut H. Ventilation effectiveness and contaminant distribution in an oceupied space conditioned with low exergy ventilation technologies in the tropies, Eindhoven, Netherlands: 2015.

[7] Chiang W H, Wang C Y, Huang J S. Evaluation of cooling ceiling and mechanical ventilation systems on thermal comfort using CFD study in an office for subtropical region. Build Enviren 2012;48:113 27. doi:10.1016/j.buildenv.2011.09.002

[8] Wang W, Tian Z. Indoor thermal comfort research on the hybrid system of radiant cooling and dedicated outdoor air system. Front Energy 2013;7:155 60. doi:10.1007/s11708-013 $0244 \mathrm{z}$.

[9] Schiaven S, Batman F, Tully B, Rimmer J. Room air stratifieation in combined chilled ceiling and displacement ventilation systems. HVACR Res 2012;18:147 59. doi:10.1080/10789669.2011.592105.

[10] Olesen BW. Radiant Floor Cooling Systems. ASHRAE J 2008;50:16 22.

[11] Feng J (Dove), Schiavon S, Batman F. Cooling load differences between radiant and air systems. Energy Build 2013;65:310 21. doi:10.1016/j.enbuild.2013.06.009.

[12] Peel MC, Finlaysen BL, MeMahon TA. Updated world map of the Köppen-Geiger elimate classification. Hydrol Earth Syst Sei 2007;11:1633 44. doi:10.5194/hess 11 16332007.

[13] Ameen A, Mahmud K. Desiccant Dehumidification with Hydronic Radiant Cooling System for AirEonditioning Applieations in Hemid Tropieal Climates. ASHRAE Trans 2005;111:225 37.

[14] Kosonen R, Tan F. A feasibility study of a ventilated beam system in the hot and humid climate: a casestudy approach. Build Environ 2005;40:1164 73. doi:10.1016/j.buildenv.2004.11.006.

[15] Vangtook $P$, Chirarattananon S. An experimental investigation of applieation of radiant cooling in hot humid climate. Energy Build 2006;38:273 85. doi:10.1016/j.enbuild.2005.06.022.

[16] Vangtook P, Chirarattananon S. Application of radiant cooling as a passive cooling option in hot humid elimate. Build Enviren 2007;42:543 56. doi:10.1016/j.buildenv.2005.09.014.

[17] Wahed MA, Wong YW, Toh KC, Ho HK. Performance Analysis of Thermally Regenerated Desiceant System Integrated With Chilled Beam for Warm Humid Climate. ASME 2010 Int. Mech. Eng. Congr. Expo., 2010, p. 1375-82. doi:10.1115/IMECE2010-40263. 
[18] Binghooth AS, Zainal ZA. Performance of desiccant dehumidification with hydronic radiant cooling system in hot humid climates. Energy Build 2012:51:1 5. doi:10.1016/j.enbuild.2012.01.031.

[19] Saber EM, Iyengar R, Mast M, Meggers F, Tham KW, Leibundgut H. Thermal comfort and IAQ analysis of a decentralized DOAS system coupled with radiant cooling for the tropics. Build Environ 2014;82:361-70. doi:10.1016/j.buildenv.2014.09.001.

[20] Meggers F, Pantelic J, Baldini L, Saber EM, Kim MK. Evaluating and adapting low exergy systems with decentralized ventilation for tropical climates. Energy Build 2013;67:559-67. doi:10.1016/j.enbuild.2013.08.015

[21] Iyengar RS, Saber E, Meggers F, Leibundgut H. The feasibility of performing high temperature radiant cooling in tropical buildings when coupled with a decentralized ventilation system. HVACR Res 2013;19:992 1000. doi:10.1080/10789669.2013.826065.

[22] Yau YH, Hasbi S. Field analysis of indoor air quality in high rise and low rise green offices with radiant slab cooling systems in Malaysia. Indoor Built Environ 2013:1420326X13506130. doi: $10.1177 / 1420326 \times 13506130$.

[23] Tantiwichien A UW, Taweekun J. An Experimental and Simulated Study on Thermal Comfort. IACSIT Int J Eng Technol 2013;5:177-80

[24] Sastry G, Rumsey P. VAV vs. Radiant Side-by-Side Comparison. ASHRAE J 2014;56:16 24.

[25] Nutprasert N, Chaiwiwatworakul P. Radiant Cooling with Dehumidified Air Ventilation for Thermal Comfort in Buildings in Tropieal Climate. Energy Procedia 2014;52:250 9. dei:10.1016/j.egypro.2014.07.076

[26] Seshadri B, Sapar MBH, Jian Z, Neth M, Wu B, Ng D. Feasibility Study of Chilled Ceiling Technology in Singapore through Simulation and Verification. Build. Simul. Optim. Conf., London: 2014.

[27] Khan Y, Khare VR, Mathur J, Bhandari M. Performance evaluation of radiant cooling system integrated with air system under different operational strategies. Energy Build 2015;97:118 28. dei:10.1016/j.enbuild.2015.03.030.

[28] Bruelisaner M, Chen K, Iyengar R, Leibundgut H, Li C, Li M, Mast M, Meggers F, Miller C, Dino R, Saber EM, Schlueter A, Tham KW. BubbleZERO Design, Construction and Operation of a

Transportable Research Laboratory for Low Exergy Building System Evaluation in the Tropics. Energies $2013: 6: 4551$ 71. dei:10.3390/en6094551.

[29] Saber E, Meggers F, Iyengar R. The potential of low exergy building systems in the tropies Prototype evaluation from the BubblezERO in Singapere. Proc. Clima 2013 Energy Effic. Smart Healthy Build. Prague, Czech Republic: 2013.

[30] Doyon T. Chiller Design For Low-Lift Conditions. Air Cond Heat Refrig News 2008;234:13-5.

[31] Indraganti M, Ooka R, Rijal HB, Brager GS. Adaptive model of thermal comfort for offices in hot and humid climates of India. Build Enviren 2014:74:39 53. dei:10.1016/j.buildenv.2014.01.002.

[32] Willem HC, Tham KW. Asseciations between thermal perception and physiological indicaters under moderate thermalstress. 6th Int. Conf. Indoer Air Qual. Vent. Energy Conserv. Build. Sustain. Built Enviren., 2007.

[33] Gong N, Tham KW, Melikev AK, Wyon DP, Sekhar SC, Cheong KW. The Aceeptable Air Velocity Range for Loeal Air Movement in The Tropies. HVACR Res 2006;12:1065 76. doi: 10.108010789669 .2006 .10391451$.

[34] Andreasi WA, Lamberts R, Cândido C. Thermal aeceptability assessment in buildings located in hot and humid regions in Brazil. Build Enviren 2010;45:1225 32. doi:10.1016/j.buildenv.2009.11.005.

[35] ASHRAE 55. ANSHASHRAE Standard 55 2004: Thermal Envirenmental Conditions for Human Oecupancy. Atlanta, GA: American Society of Heating, Refrigerating and Air Conditioning Engineers; 2004.

[36] International Standard. ISO 7730:2005 Ergonomies of the thermal envirenment Analyticat determination and interpretation of thermal comfort using caleulation of the PMV and PPD indices and local thermal comfort criteria. Geneva, Switzerland: ISO 2005; 2005.

[37] SS 554. SS 554:2009, Code of practice for indoor air quality for air conditioned buildings. Singapere: SPRING Singapere; 2009 .

[38] MS 1525. Code of Practice on Energy Efficiency and Use of Renewable Energy for Non Residential Buildings. Putrajaya, Malaysia:: Department of Standards Malaysia; 2007.

[39] Kwong QJ, Arsad MA, Adam NM. Evaluation of Indoor Thermal Environment in a Radiant-Cooled-Floor Office Building in Malaysia. Appl Mech Mater 2014;564:228 33. dei:10.4028/ww.seientific.net/AMM.564.228.

[40] American Society of Heating R and A CE. 2012 ASHRAE Handbook HVAC Systems and Equipment: AIR-CONDHTIONING AND HEATING SYSTEMS, Chap. 6, Panel Heating and Cooling 2012.

[41] Wongkee S, Chirarattananon S, Chaiwiwatworakul P. A Field Study of Experimental of Radiant Cooling for Residential Building in a Tropical Climate. Jounal Autom Control Eng 2014;2:67-70. 
[42] Rumsey P, Weale J. Chilled Beams in Labs Eliminating Reheat \& Saving Energy on a Budget. ASHRAE J 2007:49.

[43] Alexander D, O'Rourke M. Design Considerations For Active Chilled Beams. ASHRAE J 2008:50 8.

[44] Kim MK, Leibundgut $\mathrm{H}$. Evaluation of the humidity performance of a novel radiant cooling system connected with an Airbox convector as a low exergy system adapted to hot and humid climates. Energy Build 2014;84:224-32. doi:10.1016/j.enbuild.2014.08.005.

[45] Kim MK, Leibundgut H. A case study on feasible performance of a system combining an airbox convector with a radiant panel for tropical climates. Build Environ 2014;82:687-92. doi:10.1016/j.buildenv.2014.10.012.

[46] SS 553. SS 553:2009, Code of practice for air-conditioning and mechanical ventilation in buildings. Singapore: SPRING Singapore; 2009.

[47] Saber E, Mast M, Tham KW, Leibundgut H. Numerical Modelling of an Indoor Space Conditioned with Low Exergy Cooling Technologies in the Tropics. 13th Int. Conf. Indoor Air Qual. Clim., Hong Kong: 2014.

[48] Jeong J W, Mumma SA, Bahnfleth WP. Energy conservation benefits of a dedieated outdoer air system with parallel sensible cooling by ceiling radiant panels. ASHRAE Trans 2003;109:627-36.

[49] Stein J, Taylor ST. VAV Reheat Versus Active Chilled Beams \& DOAS. ASHRAE J 2013:18-32.

[50] Nóbrega CEL, Brum NCL. An Introduction to Solid Desiccant Coøling Technology. In: Nóbrega CEL, Brum NCL, editors. Desiceant Assist. Cool., Springer London; 2014, p. 123.

[51] ASHRAE. Ashrae Handbook: HVAC Systems and Equipment. vol. Chapter 44: Air to Air Energy Recovery. 2000.

[52] Nasif M, AL-Waked R, Morrison G, Behnia M. Membrane heat exchanger in HVAC energy recovery systems, systems energy analysis. Energy Build 2010;42:1833-40. doi:10.1016/j.enbuild.2010.05.020

[53] Wyssen I, Gasser L, Wellig B, Meier M. Chiller with small temperattre lift for efficient building cooling. Proc Clima, Antalya, Tukkey: 2010. 


\title{
A review of high temperature cooling systems in tropical buildings
}

\author{
Esmail M. Saber* ${ }^{1,2}$ Kwok Wai Tham ${ }^{1}$ Hansjürg Leibundgut ${ }^{3}$ \\ ${ }^{1}$ Department of Building, School of Design and Environment, National University of Singapore, Singapore \\ ${ }^{2}$ Singapore-ETH Centre for Global Sustainability, Future Cities Laboratory, Swiss Federal Institute of Technology (ETH), Zurich, \\ Switzerland \\ ${ }^{3}$ Institute of Technology in Architecture, Swiss Federal Institute of Technology (ETH), Zurich, Switzerland \\ * Corresponding author. Tel.: +6592279136 \\ E-mail address: emsaber@u.nus.edu (Esmail M. Saber).
}

\begin{abstract}
\end{abstract}
High temperature cooling is gaining more attention in commercial buildings of the tropical climates where temperature and humidity is high all year round. In this air-water system, radiant-convective cooling is provided into conditioned space through using higher chilled water temperature compared to conventional all air system. Radiant cooling panel, radiant slab cooling, passive/active chilled beams are the main design strategies for implementing this concept into buildings. This paper reviewed and summarized the recent published papers on applications of high temperature cooling systems in tropical buildings. The reported outcomes and conclusions from these studies were extracted and discussed to get a better understanding on overall performance of the systems which are designed based on this concept. The potential energy saving of this strategy was estimated to be in the range of 6 to $41 \%$ depending on design strategies and operational scenarios of system. Comfortable and healthy indoor environment is achievable for this design when a parallel air system satisfies latent load and ventilation requirement of space. Low air movement was the only reported comfort concern for this design since locally acclimatized occupants in the tropics prefer higher air movement compared to dry and temperate climates. Regarding the parallel air system strategy, DOAS with ceiling supply-ceiling exhaust is suggested to be the best choice to be coupled with high temperature cooling system. In addition, incorporation of energy recovery systems like membrane based air to air heat exchanger into DOAS can improve the overall efficiency of this design. 
Keywords -High Temperature Cooling; Radiant cooling; air-water system; DOAS; energy saving; Tropical Buildings

\section{Abbreviations}

CFD

CE

COP

CHWS

CHWR

CS

DDOAS

DOAS

DV

EA

ERS

FS

IAQ

HTC

HTCW

HVAC

LTC

LTCW

$\mathrm{MF}$

MHX

NV

$\mathrm{OA}$

PCB

PMV

PPD

RA

RAS

RCS

RCP

RDD

RSC

SA

TABS

VAV
Active Chilled Beam

Air Conditioning and Mechanical Ventilation

Air Handling Unit

Constant Air Volume

Chilled Ceiling

Computational Fluid Dynamics

Ceiling Exhaust

Coefficient of Performance

Chilled Water Supply

Chilled Water Return

Ceiling Supply

Decentralized Dedicated Outdoor Air System

Dedicated Outdoor Air System

Displacement Ventilation

Exhaust Air

Energy Recovery System

Floor Supply

Indoor Air Quality

High Temperature Cooling

High Temperature Chilled Water

Heating, Ventilation, and Air Conditioning

Low Temperature Cooling

Low Temperature Chilled Water

Mechanical Fan

Membrane Heat exchanger

Natural Ventilation

Outdoor Air

Passive Chilled Beam

Predicted Mean Vote

Predicted Percentage Dissatisfied

Return Air

Recirculated Air System

Radiant Cooling System

Radiant Cooling Panel

Rotary Desiccant Dehumidifier

Radiant Slab Cooling

Supply Air

Thermally Activated Building System

Variable Air Volume

\section{Introduction}

Our collective concern regarding the global warming is slowly changing the way we behave and act in different aspects of our lives in order to reduce our daily $\mathrm{CO}_{2}$ footprints. Governments started proactively encouraging communities and companies to implement green technologies at different sectors including building industry. In the tropical context where 
temperature and humidity are high all year round, air conditioning and mechanical ventilation systems (ACMV) is a necessity for commercial buildings. Several governmental and International reports in tropical countries revealed that ACMV system consumes around half of electricity use in commercial buildings [1]. Central all air system is the conventional cooling system in tropical buildings where central chilled water plant provides chilled water for air handling units which covers several thermal zones. The amount and temperature of conditioned air to each zone could be controlled by variable or constant air volume (VAV/CAV) through a user controlled thermostat located inside the conditioned space. High temperature cooling (HTC) concept introduces a new design by using higher temperature chilled water $\left(\approx 16{ }^{\circ} \mathrm{C}\right)$ compared to the conventional design $\left(\approx 6{ }^{\circ} \mathrm{C}\right)$. HTC design incorporates a water based system to provide sensible cooling in the conditioned space while a parallel air based system usually handles latent load and ventilation requirements of indoor space. The energy performance superiority of this design comes from the facts that water is a more efficient medium for heat transfer compared to air and high temperature chilled water can be provided at higher chiller COP.

The implications of HTC strategies like radiant cooling panel, radiant slab cooling, passive/active chilled beam have been extensively explored for the temperate and dry climates. Novoselac and Srebric [2] provided a dimensionless performance metric of chilled ceiling combined with displacement ventilation and concluded that it may or may not save energy compared to all air system depending on operational parameters like supply air temperature and outdoor flow rate. Tian and Love [3] conducted energy simulation analysis for application of radiant slab cooling and showed that energy saving potentials range between 10 to $40 \%$ for different climate types. In another study, Mumma [4] estimated that VAV costs about $29 \%$ more to operate compared to DOAS-RCP system for humid subtropical climate of 
Philadelphia in US. He also argued that it takes hours for condensation film to appear on radiant panel in the case occupancy level increases by a factor of 2 or 3 from design level [5].

The operational conditions and arrangements of HTC and air system in the indoor space play an important role on indoor air characteristic indices like thermal stratification and ventilation effectiveness [6]. Chiang et al. [7] evaluated the performance of CC-DV for the subtropical climate of Taiwan and suggested supply temperature in the range of 18 to $24{ }^{\circ} \mathrm{C}$ to reduce thermal stratification in the space. No concern of condensation on radiant ceiling surface was reported for this range of supply temperature which could be due to the low dew point level at supply air or low latent load of the lab. Nevertheless, the PMV of indoor space was not in comfortable range at supply air of $24{ }^{\circ} \mathrm{C}$. The results of their CFD simulation also showed that floor air supply in this design performs better than ceiling supply. On the contrary, Wang and Tian [8] concluded that ceiling delivery and ceiling exhaust is the optimized arrangement for a hybrid radiant cooling and DOAS system. Based on their findings, impact significance of design factors has an order of air supply temperature > panel coverage area > panel temperature > air supply volume. In addition, Schiavon et al. [9] found a strong correlation between indoor thermal stratification and average temperature of radiant panel surface for CC-DV design. The shift in cooling strategy from all air system to air-water system has also some impacts on heat gain level of buildings. It has been reported that there is an increase of building cooling load for the implemented case of radiant cooling system and efforts should be made to avoid direct sun shines on HTC system [10]. Feng et al. [11] developed a simulation tool to investigate the magnitude of this cooling load difference between radiant cooling and all air system. They found 5 to $15 \%$ increase in average diurnal cooling load compared to all air system and the level of increase was predicted to be higher for floor cooling system. 
In this paper, the reported studies in the literature on the applications of high temperature cooling in the tropical context were reviewed. The scope of this review was limited to the research studies conducted in or for the tropical climate based on the Köppen-Geiger climate classification [12]. The group A of this classification includes tropical rainforest, tropical monsoon, and tropical wet and dry (savanna) climates which are characterized as high temperatures $\left(\geq 18^{\circ} \mathrm{C}\right)$ and precipitations all year round except for dry season in monsoon and savanna climates. These climates usually occur in the areas near the equator and cover various countries in Asia, Africa and America like Singapore, Malaysia, Thailand, Indonesia, Philippine, Brazil, and India. The average monthly variation of temperature and dew point for three climates of tropical rainforest (Singapore, Kuala Lumpur, Jakarta and etc.), hot desert (Phoenix, Doha, Dubai and etc.) and warm temperate (Hanoi, Hong Kong, Taipei and etc.) are illustrated in Fig. 1. In the tropical climate of Singapore, temperature and dew point remain almost unchanged in the course of a year while in two other cities there is a clear warm season which happens between May to September. The warm temperate climate of Hanoi exhibits similar profile to the tropics during warm season where dew point is close to $25{ }^{\circ} \mathrm{C}$. On the other hand, at hot desert climate of Phoenix in Arizona, dew point level is unlikely to exceed $15^{\circ} \mathrm{C}$. 


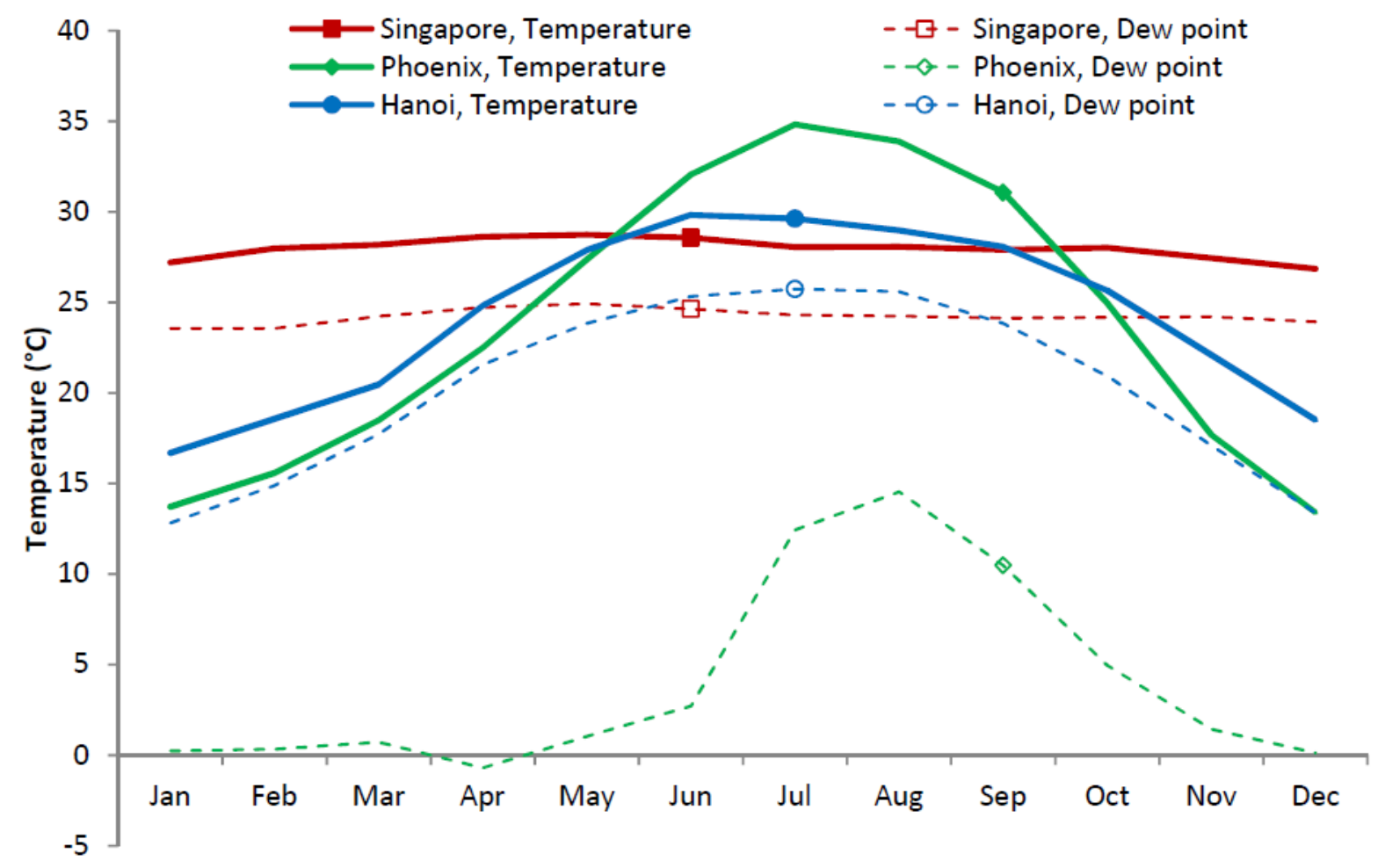

Fig. 1 The monthly variation of temperature and dew point for three cities of Singapore (average of 1956-2015), Phoenix (average of 1948-2015) and Hanoi (average of 1959-2015)

The google scholar website has been chosen as the main platform and searches were conducted based on combined keywords of "high temperature cooling", "radiant cooling", "slab cooling", "chilled beam", "tropics" and "hot and humid". Thirty eight papers on high temperature cooling system in the tropics and 45 papers on generic applications of HTC have been selected in the early stages. Based on relevance and originality of investigations, 27 and 17 papers were chosen for final investigation respectively for tropical and generic applications of HTC. The outcomes and conclusions from the reported studies were extracted and discussed on different aspects of HTC applications including energy saving, thermal comfort, design strategies and operational scenarios. A collection of design strategies and system components was introduced for efficient implementation of high temperature cooling systems in tropical buildings based on the collected information from the papers. 


\section{High temperature cooling in tropical buildings}

\subsection{Energy Saving Potential}

High temperature cooling systems have the potential to reduce power consumption of ACMV systems in buildings by using high temperature chilled water as heat transfer medium. In the tropical context, high humidity ambient air condition requires a more advanced design and control strategy in order to avoid condensation risk. Different amounts of energy saving was reported in the literature for the implementation of high temperature cooling systems in the tropics. The percentages of energy saving for the main reported studies in the literature are listed in Table 1. Majority of studies found the HTC systems more energy efficient compared to the conventional system. The level of savings ranged between 6 to $41 \%$ while in some design or operational scenarios, this concept consumed even more energy. The conventional systems in the tropics are usually central all air system for office use and split unit air conditioner for residential applications.

Table 1 List of reported studies in the literature on high temperature cooling systems applications in tropical buildings

\begin{tabular}{|c|c|c|c|c|c|c|}
\hline $\begin{array}{l}\text { Authors } \\
\text { (year) }\end{array}$ & $\begin{array}{c}\text { HTC } \\
\text { system }\end{array}$ & $\begin{array}{c}\text { Air system } \\
\text { / distribution } \\
\end{array}$ & $\begin{array}{c}\text { City / Climate } \\
\text { Type }\end{array}$ & $\begin{array}{c}\text { Investigation } \\
\text { approach }\end{array}$ & $\begin{array}{c}\text { Supply } \\
\text { water to } \\
\text { HTC } \\
\end{array}$ & $\begin{array}{c}\text { Energy } \\
\text { saving }\end{array}$ \\
\hline $\begin{array}{l}\text { Ameen and } \\
\text { Khizir [14] }\end{array}$ & $\mathrm{RCP}$ & RDD/DV & $\begin{array}{l}\text { Pulau Pinag, } \\
\text { Malaysia / } \\
\text { Tropical } \\
\text { rainforest }\end{array}$ & $\begin{array}{l}\text { Experimental } \\
\text { setup in a test } \\
\text { chamber }\end{array}$ & $\begin{array}{c}13^{\circ} \mathrm{C} \\
\text { (panel } \\
\text { surface } \\
15-18^{\circ} \mathrm{C} \text { ) }\end{array}$ & $\begin{array}{c}-51 \% \\
\text { to } 35 \%\end{array}$ \\
\hline $\begin{array}{l}\text { Kosonen and } \\
\text { Tan [15] }\end{array}$ & $\mathrm{ACB}$ & $\begin{array}{l}\text { DOAS/CS- } \\
\text { CE }\end{array}$ & $\begin{array}{c}\text { Singapore / } \\
\text { Tropical } \\
\text { rainforest }\end{array}$ & $\begin{array}{l}\text { Field } \\
\text { measurement in } \\
\text { a case study }\end{array}$ & $16-17^{\circ} \mathrm{C}$ & NA \\
\hline $\begin{array}{c}\text { Vangtook and } \\
\text { Chirarattanano } \\
\text { n }[16,17]\end{array}$ & $\mathrm{RCP}$ & MF & $\begin{array}{l}\text { Central } \\
\text { Thailand / } \\
\text { tropical } \\
\text { savanna } \\
\end{array}$ & $\begin{array}{c}\text { Experimental } \\
\text { setup and } \\
\text { Building energy } \\
\text { modeling } \\
\end{array}$ & $24-25^{\circ} \mathrm{C}$ & $\begin{array}{l}-100 \% \\
\text { to } 6 \%\end{array}$ \\
\hline $\begin{array}{c}\text { Wahed et al. } \\
{[18]}\end{array}$ & $\mathrm{ACB}$ & RDD & $\begin{array}{l}\text { Singapore / } \\
\text { Tropical } \\
\text { rainforest }\end{array}$ & $\begin{array}{l}\text { Building Energy } \\
\text { modeling }\end{array}$ & $18^{\circ} \mathrm{C}$ & $\begin{array}{l}10 \text { to } \\
20 \%\end{array}$ \\
\hline
\end{tabular}




\begin{tabular}{|c|c|c|c|c|c|c|}
\hline $\begin{array}{c}\text { Binghooth and } \\
\text { Zainal [19] }\end{array}$ & $\mathrm{RCP}$ & RDD & $\begin{array}{l}\text { Penang, } \\
\text { Malaysia / } \\
\text { Tropical } \\
\text { rainforest }\end{array}$ & $\begin{array}{l}\text { Experimental } \\
\text { setup in a test } \\
\text { chamber }\end{array}$ & $\begin{array}{c}6-10^{\circ} \mathrm{C} \\
\text { (panel } \\
\text { surface } \\
14-18^{\circ} \mathrm{C} \text { ) }\end{array}$ & NA \\
\hline $\begin{array}{c}\text { Saber et al. } \\
\text { [20] Meggers } \\
\text { et al. [21] } \\
\text { Iyengar et al. } \\
\text { [22] }\end{array}$ & $\mathrm{RCP}$ & $\begin{array}{c}\text { DDOAS/FS } \\
-\mathrm{CE}\end{array}$ & $\begin{array}{l}\text { Singapore / } \\
\text { Tropical } \\
\text { rainforest }\end{array}$ & $\begin{array}{l}\text { Experimental } \\
\text { setup in a test } \\
\text { chamber }\end{array}$ & $\begin{array}{c}17-19^{\circ} \mathrm{C} \\
\text { (panel } \\
\text { surface } \\
18-22^{\circ} \mathrm{C} \text { ) }\end{array}$ & NA \\
\hline $\begin{array}{c}\text { Yau and Hasbi } \\
{[23]}\end{array}$ & RSC & VAV & $\begin{array}{c}\text { Kuala Lumpur, } \\
\text { Malaysia / } \\
\text { Tropical } \\
\text { rainforest }\end{array}$ & $\begin{array}{l}\text { Field } \\
\text { measurement in } \\
\text { two case studies }\end{array}$ & $19^{\circ} \mathrm{C}$ & NA \\
\hline $\begin{array}{c}\text { Tantiwichien } \\
\text { and Taweekun } \\
{[24]}\end{array}$ & $\mathrm{RCP}$ & MF & $\begin{array}{l}\text { Songkhla, } \\
\text { Thailand / } \\
\text { tropical } \\
\text { monsoon }\end{array}$ & $\begin{array}{c}\text { Field } \\
\text { measurement } \\
\text { and Building } \\
\text { energy } \\
\text { modeling } \\
\end{array}$ & $25^{\circ} \mathrm{C}$ & $41 \%$ \\
\hline $\begin{array}{c}\text { Sastry and } \\
\text { Rumsey [25] }\end{array}$ & $\begin{array}{l}\text { RSC } \\
\text { and } \\
\text { PCB }\end{array}$ & DOAS & $\begin{array}{c}\text { Hyderabad- } \\
\text { India / tropical } \\
\text { savanna }\end{array}$ & $\begin{array}{c}\text { Field } \\
\text { measurement in } \\
\text { a case study }\end{array}$ & $14^{\circ} \mathrm{C}$ & $34 \%$ \\
\hline $\begin{array}{l}\text { Nutprasert and } \\
\text { Chaiwiwatwor } \\
\text { akul [26] }\end{array}$ & $\mathrm{RCP}$ & MF-FCU & $\begin{array}{c}\text { Bangkok, } \\
\text { Thailand / } \\
\text { tropical } \\
\text { savanna }\end{array}$ & $\begin{array}{c}\text { Experimental } \\
\text { setup and } \\
\text { Building energy } \\
\text { modeling }\end{array}$ & $21-25^{\circ} \mathrm{C}$ & NA \\
\hline $\begin{array}{c}\text { Seshadri et al. } \\
\text { [27] }\end{array}$ & $\mathrm{RCP}$ & VAV & $\begin{array}{l}\text { Singapore / } \\
\text { Tropical } \\
\text { rainforest }\end{array}$ & $\begin{array}{l}\text { Experimental } \\
\text { setup and } \\
\text { Building energy } \\
\text { modeling }\end{array}$ & $15^{\circ} \mathrm{C}$ & $26 \%$ \\
\hline $\begin{array}{c}\text { Khan et al. } \\
\text { [28] }\end{array}$ & RSC & DOAS-FCU & $\begin{array}{l}\text { Hyderabad- } \\
\text { India / tropical } \\
\text { savanna }\end{array}$ & $\begin{array}{c}\text { Experimental } \\
\text { setup and } \\
\text { Building } \\
\text { Simulation tools }\end{array}$ & $<16^{\circ} \mathrm{C}$ & $\begin{array}{c}17.5 \text { to } \\
30 \%\end{array}$ \\
\hline
\end{tabular}

Compared to conventional system, air-water systems can potentially save energy through further use of water as heat transport medium in order to lower fan energy use and duct size. The heat capacity of water $\left(4.183 \mathrm{~kJ} /(\mathrm{kg} . \mathrm{K}) @ 20{ }^{\circ} \mathrm{C}\right)$ is four times more than air $(1.005$ $\left.\mathrm{kJ} /(\mathrm{kg} . \mathrm{K}) @ 20{ }^{\circ} \mathrm{C}\right)$, and consequently the heat transfer exchange process is potentially more efficient with water. The main opportunity for energy saving in high temperature cooling design comes from downsizing the supply air fan. The radiant cooling system could satisfy some part of space sensible load which brings the chance to reduce the amount of supply air volume or even just to limit it to ventilation air. In one study in the tropics, Vangtook and 
Chirarattananon [17] conducted annual energy simulations based on measured data in a $16 \mathrm{~m}^{2}$ laboratory space in which radiant cooling panels were implemented as active wall and ceiling panel. The results of simulations showed that total fan energy use can be cut to half by using radiant panel instead of conventional air conditioning concept. In another study, Khan et al. [28] investigated thermal performance and energy saving potential of radiant cooling system in commercial buildings of Hyderabad in India through CFD and energy simulations. Annual energy consumption data revealed that $70 \%$ of fan energy consumption can be reduced by implementing DOAS combined with slab cooling. While in both of reported studies, water pump energy use in radiant cooling system increased almost by three times, overall required energy for air circulation were much higher than water circulation. A research group in the tropical climate of Singapore introduced the idea of decentralized DOAS (DDOAS) combined with radiant cooling based on low exergy concept to bring chilled water closer to the conditioned space and further reduce the fan energy use [29,30]. The Energy Conservation in Buildings and Community Systems (ECBCS) group of International Energy Agency (IEA) has provided several reports on implementation of low exergy cooling systems in buildings [3133]. High temperature radiant slab cooling has been categorized in these reports as the low exergy cooling system where temperature lift is reduced through use of higher chilled water temperature.

High temperature cooling concept can accommodate another aspect of energy saving in refrigeration system of chiller compared to all air system. Incorporating radiant cooling systems in buildings facilitates use of higher CHWS temperature which can potentially save energy by using a custom designed chiller for low temperature lift conditions. This higher evaporator temperature can reduce the compressor work because of lower operational temperature and pressure lift. The refrigeration cycles on pressure-enthalpy diagrams for two cases of low temperature and high temperature cooling are shown in Fig. 2. As can be seen in 
this graph, with reduction of lift between low and high pressure side of refrigeration cycle, the compressor performs less work. This graph indicates the efficiency superiority of HTC concept over conventional LTC air conditioning system.
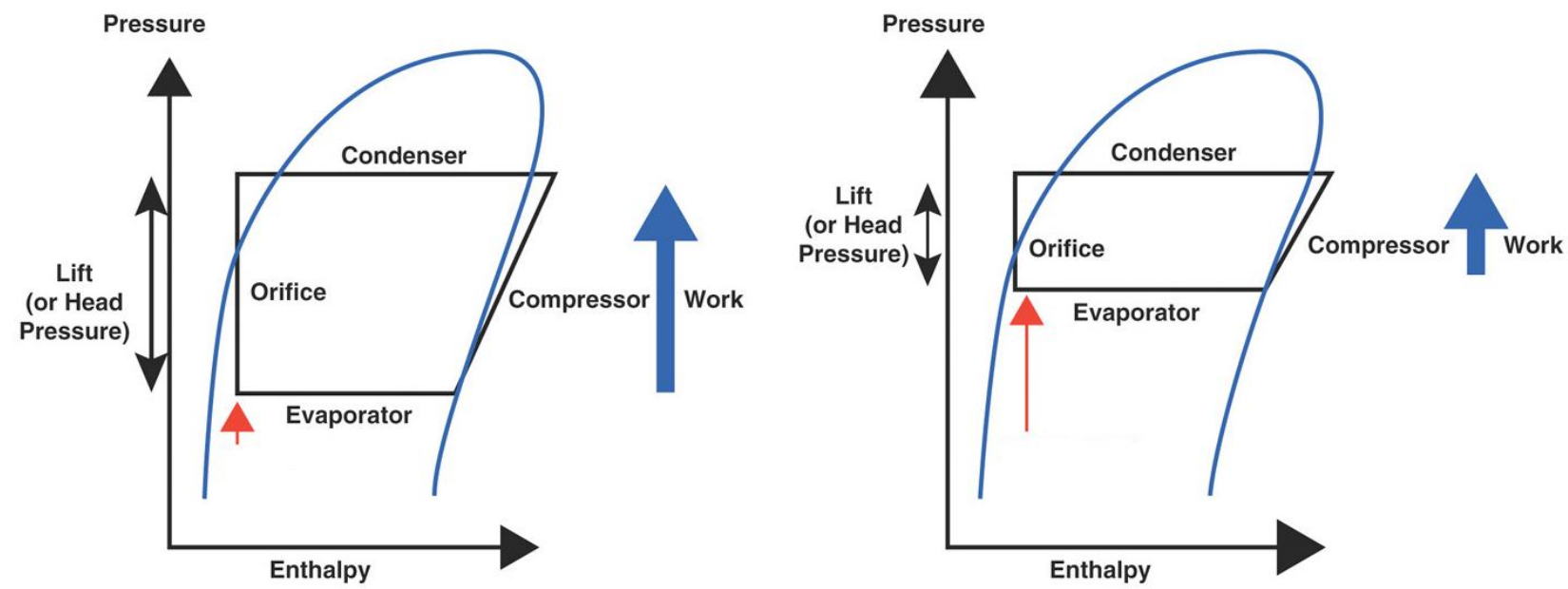

Fig. 2 Impact of raising the evaporative temperature on refrigeration cycle diagram [34]

The high temperature cooling system is required to be complemented with a parallel air system to provide a comfortable and healthy indoor environment. In the tropical context, the air based system usually requires low temperature chilled water (LTCW) for an effective dehumidification. So, the combinations of LTCW and HTCW systems are necessary to truly exploit the potential energy saving of high temperature cooling concept. Saber et al. [20] implemented two chillers for the combination of DOAS-RCS in the tropical climate of Singapore. The schematic arrangement of these two chillers operating in parallel is shown in Fig. 3. The low temperature lift chiller provided HTCW for radiant panel and the second high lift chiller was designated for dehumidification of outdoor air in decentralized air supply units. In another study, Khan et al. [28] also considered two parallel chillers to provide chilled water for AHU and slab cooling systems, separately. The results showed that this design strategy can 
reduce the annual energy consumption of chillers by $20 \%$ compared to the conventional design.

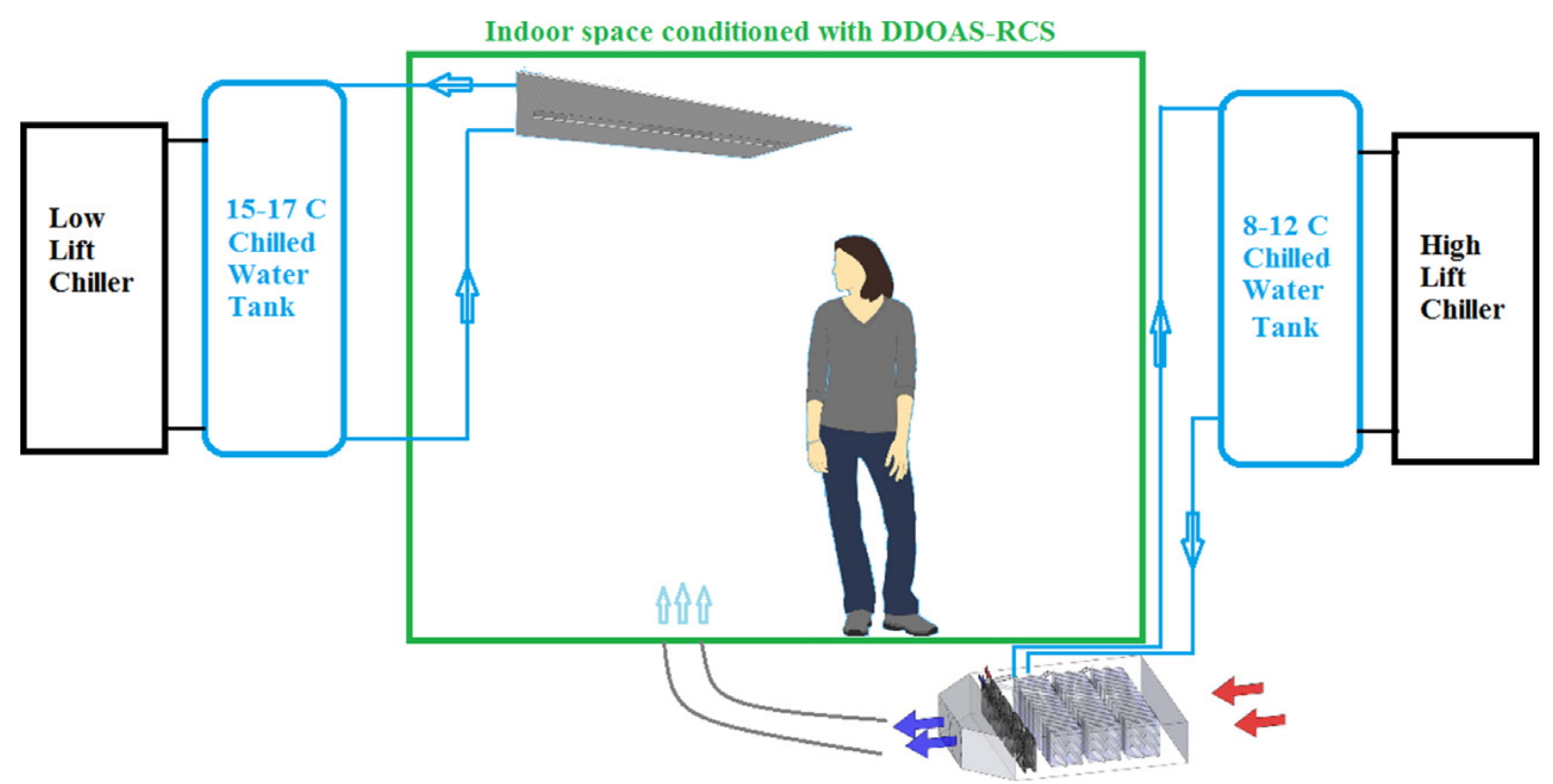

Fig. 3 Schematic diagram of decentralized DOAS-RCS with two separate low lift and high lift chillers [20]

\subsection{Thermal comfort and indoor air quality}

The main and only goal of any ACMV system is to provide comfortable and healthy indoor environment for occupants. Radiant heat transfer contribution has been enhanced in cooling of indoor space with high temperature cooling systems. This change results in a new type of conditioned space with lower air movement and mean radiant temperature compared to all air system. Thermal comfort and IAQ performance of this system could be evaluated based on the International standards and local guidelines in tropical countries. Fanger's PMV/PPD model is the most commonly used thermal comfort model in different climate types. However, the majority of comfort studies [35-38] in the tropics were concluded that locally acclimatized occupants have different perception compared to prediction of PMV model. So, a better 
understanding on actual perception of occupants in the tropics may be obtained by considering both the International and local standards' criteria.

Various design scenarios and control strategies have been exploited for implementation of HTC systems in tropical buildings. Thermal comfort was achieved adequately and accurately in some design scenarios while in other cases, indoor air was comfortable only under specific hours of day and occupant activities. In one strategy, chilled water supply temperature to $\mathrm{HTC}$ is kept around 24 to $25^{\circ} \mathrm{C}$ to be always above the outdoor dew point level in the tropical context. In parallel, fresh and humid outdoor air is brought into space through natural ventilation $(\mathrm{NV})$ or mechanical fan $(\mathrm{MF})$ for ventilation requirement or raising indoor air movement level. While condensation was avoided with this tactic, the high chilled water temperature put a restriction on capacity of HTC. This design strategy is suitable for spaces with low heat gain and only can provide comfortable indoor air space for night time residential applications under resting activity. From a favorable view, the required high temperature supply water for HTC can be provided through passive chilled water systems like cooling tower. Vangtook and Chirarattananon [16] investigated the application of radiant cooling in the tropical climate of Thailand by using natural air for ventilation and $24-25{ }^{\circ} \mathrm{C}$ chilled water for radiant panel. The results of experiments and simulation showed that the capacity of system was inadequate during hot period of the day and acceptable PMV only achieved during night time for a reclining person. In daytime occupancy and under office activity, personal fans have been considered to achieve thermal comfort [17]. In a similar study, Nutprasert and Chaiwiwatworakul [26] used supply chilled water temperature of $25 \mathrm{C}$ in radiant cooling panel combined with natural air for cooling of a space in Thailand. The results of building performance simulations showed that with this strategy, people feel warm or too warm, $71 \%$ of the time in the year. 
The second and main stream design strategy in operating high temperature cooling system in the tropics is to keep CHWS temperature to HTC below outdoor dew point. A parallel conditioned air system is required to keep the indoor dew point level below HTC operational temperature. It can be seen from the list of studies in Table 1 that the supply water temperature for this strategy ranges between 14 to $21{ }^{\circ} \mathrm{C}$ and the parallel air system could be DOAS or RAS. Almost all of the reported studies in the literature $[15,21,22,25]$ concluded that adequate comfort condition can be achieved in the tropics with this design scheme. Kosonen and Tan [15] conducted field measurements for an implemented case of active chilled beam in Singapore. They found that with off coil air temperature of $14^{\circ} \mathrm{C}$ and supplied chilled water of $17{ }^{\circ} \mathrm{C}$, indoor air condition of $23{ }^{\circ} \mathrm{C}$ and $65 \%$ relative humidity could be achieved during daytime. In another field study, Sastry and Rumsey [25] conducted a side by side comparison of radiant slab cooling and VAV all air system for the tropical climate of Hyderabad in India. Radiant cooling design provided higher satisfaction among occupants although ceiling fan was used in the indoor office space to raise the air movement level.

Low air movement in indoor space was the only identified comfort issue in the literature for application of radiant cooling systems in the tropics. There is no minimum air velocity requirement in the International standards like ASHRAE standard 55 [39] and ISO 7730 [40]. However, several local standards in tropical countries put some limit on the minimum acceptable air velocity. Local Singapore standard of SS 554 [41] recommended indoor air velocity to be in the range of 0.1 to $0.3 \mathrm{~m} / \mathrm{s}$. Malaysian local standard of MS 1525 [42] also have the recommended range of 0.15 to $0.5 \mathrm{~m} / \mathrm{s}$ for air movement level in the occupied space. Yau and Hasbi [23] assessed thermal comfort and indoor air quality level in two green buildings in Malaysia in which radiant slab cooling were implemented. The objective measurements in the buildings revealed that indoor air condition provided by radiant slab cooling is compatible with the criteria of local and International standards. The only identified 
deficiency for this concept was low air movement which was below acceptable range in local standards. In another study, Kwong et al. [43] conducted a thermal comfort survey in a green building in Malaysia with slab radiant cooling and found air velocity below the limit set by local guidelines.

\subsection{System design/operation strategy}

As explained in section 2.2, there are two main strategies in operating high temperature cooling systems in the tropics. In the first strategy, supply chilled water temperature to HTC is kept above outdoor dew point level and in the second strategy chilled water temperature is kept below outdoor dew point and dehumidification is required to avoid condensation. The main advantages of first scheme are utilizing passive chilled water system like cooling tower and less risk of condensation and system complexity. This design is mostly suitable for night time applications of residential buildings and personal fan has been advised to be used in parallel for day time applications in commercial buildings. The second strategy is able to provide adequate and accurate comfort condition under any indoor/outdoor scenarios. However, parallel operation of radiant cooling and air based dehumidification systems makes the design and control of overall system more complicated.

Radiant cooling panel (RCP), radiant slab cooling (RSC), active chilled beam (ACB) and passive chilled beam (PCB) are the common types of HTC strategies. Each system has its own advantages and drawbacks which makes it more suitable for some applications. RCP is a temperature controlled surface which is attached to a chilled water hydronic system and provides cooling into space mainly through radiation rather than convection. The infrared image of a radiant ceiling panel in a conditioned lab is shown in Fig. 4. It can be seen that temperature varies over the surface and it is colder in the areas which is in contact with water pipes. Based on ASHRAE guideline [44], by assuming indoor air and average interior surfaces 
temperature of $27^{\circ} \mathrm{C}$, capacity of radiant panel ranges between 15 to $115 \mathrm{~W} / \mathrm{m}^{2}$ for water supply temperature of 15 to $25{ }^{\circ} \mathrm{C}$. For a combined radiant panel and natural air system in the tropical climate of Thailand, radiant panel capacity was found to be in the range of 30-40 $\mathrm{W} / \mathrm{m}^{2}$ with water supply temperature of $24-25{ }^{\circ} \mathrm{C}[16,45]$. In another study in the tropical climate of Singapore, Saber et al. [20] concluded that from morning till afternoon under various supply water temperatures, radiant ceiling panel heat flux varies between 9 to 43 $\mathrm{W} / \mathrm{m}^{2}$.

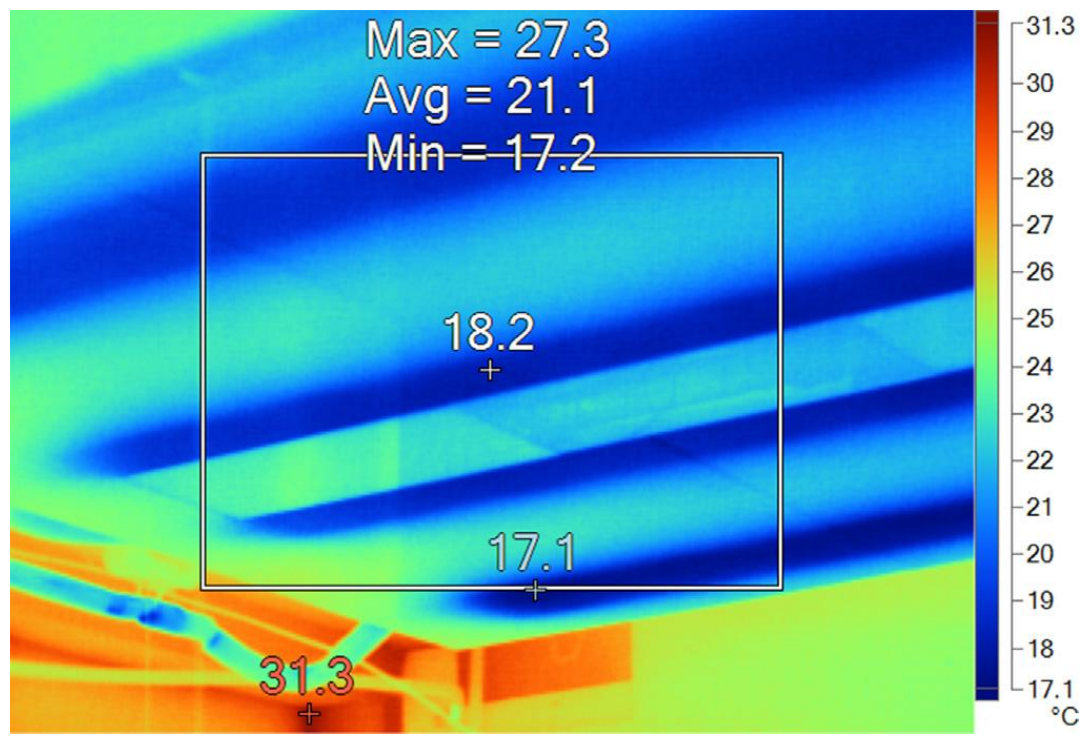

Fig. 4 Infrared image of a radiant cooling panel hung on ceiling [20]

In radiant slab cooling (RSC), water pipes are embedded into structure of building and it provides mostly radiant cooling from floor or ceiling. This system requires integration with building structure and needs to be planned at design stage before concrete pour (Fig. 5). RSC also employs thermal mass of structure in order to shift and reduce peak cooling load of building. Compared to radiant cooling panel, this design is more suitable for spaces where steady cooling is required for a length of time. RCP can adjust faster to change in cooling load and have better acoustical dampening as well as the option to be integrated with other building 
systems like lighting. International standard organization on building environmental design section provided guidelines for design, dimensioning, installation and control of embedded radiant cooling system into structure of building as thermally activated building systems (TABS) [46].

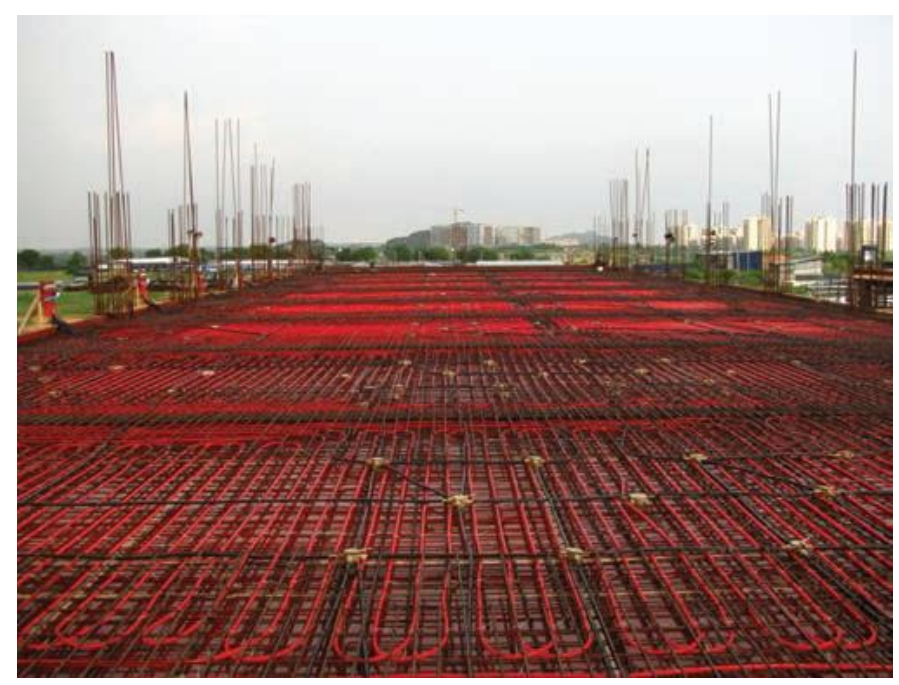

Fig. 5 Water pipes in slab cooling system [25]

High temperature cooling system can be implemented in buildings through convective based system of chilled beam in which chilled water passes through a heat exchanger located inside the conditioned space. Passive chilled beam is usually suspended on the ceiling and provides sensible cooling through convective heat transfer with surrounding air. Warm air adjacent to coils gets cooler and denser so it moves downward and causes a natural convection flow in the indoor space. The perforated metal casing in Fig. 6 is for providing comfortable cooling with aesthetic advantages and typically it has $50 \%$ open area. The implication of passive chilled beam has not been explicitly explored in the literature for the tropical context while it is known that PCB can provide fast response cooling and is suitable for spaces with high cooling load requirements [25]. 


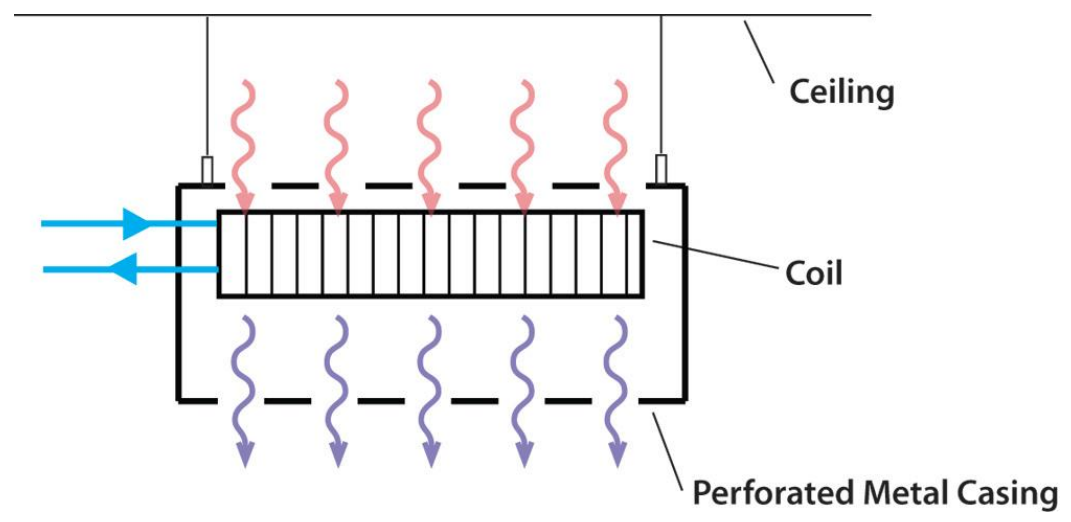

Fig. 6 A passive chilled beam in operation [47]

In high temperature cooling systems like RCP, RSC and PCB, water based and air based systems are operating independently in parallel. In active chilled beam design, conditioned air passes through heat exchanger to enhance heat transfer mechanism between air and pipes. The schematic of an operating active chilled beam is shown in Fig. 7. The primary ventilation air mixes with secondary room air to supply dehumidified and cool air into space. In the tropical context, the main design consideration for implementation of ACB is to avoid condensation on beam and maintain dry cooling in the units. Kosonen and Tan [15] investigated an implemented case of ACB in Singapore office building and concluded that condensation in ACB unit is possible to be avoided by minimizing infiltration, supplying sufficient conditioned air and adequate control of system. 


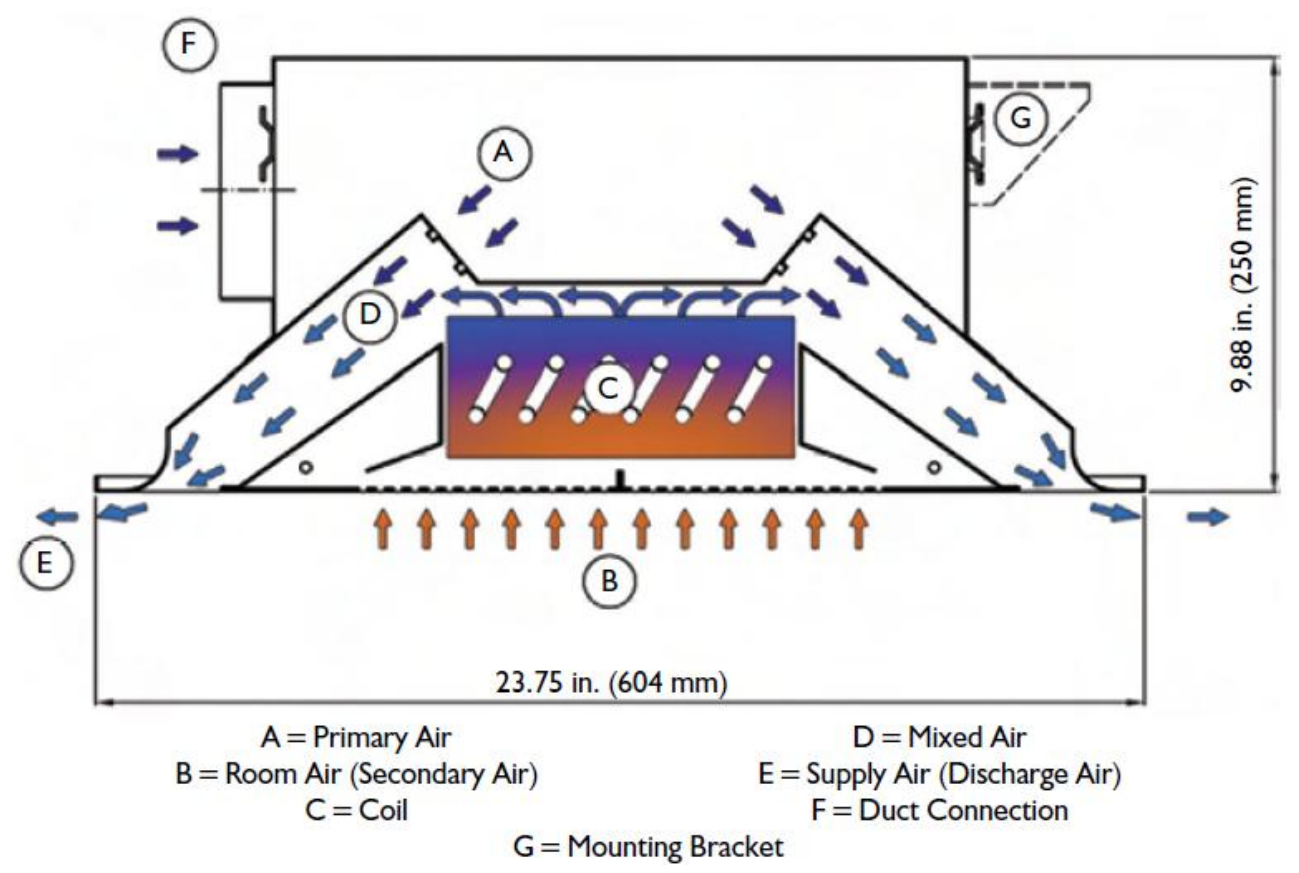

Fig. 7 An active chilled beam in operation [48]

An air based system is required to work in parallel to high temperature cooling device to handle latent load and ventilation requirement of indoor space. This air system could be a central DOAS-VAV, RAS-VAV design or even a decentralized DOAS or FCU located near the conditioned space. In the ideal operational scenario, air system design accommodates utilizing the most achievable cooling capacity from high temperature cooling system and it satisfies main part of space sensible load. In DOAS design, supply air is only limited to ventilation outdoor air and it can bring the opportunity to downsize AHU and reduce duct size and fan energy use compared to the all air system. Khan et al. [28] conducted energy simulation analysis for applications of radiant cooling system in the tropics and showed that radiant cooling combined with DOAS can provide $12.8 \%$ higher energy saving compared to RSC-FCU design. The coupled design of decentralized DOAS-RCP $[22,49,50]$ can bring chilled water closer to the indoor space by using small decentralized air supply units integrated into building structure and further cut the fan energy use. DOAS design suits spaces with air tight façades and low latent load where dehumidified fresh air could bring down indoor dew 
point below HTC operational temperature. For spaces with high infiltration rate, reconditioning of return air (RA) in RAS design can result in a more efficient system rather than DOAS. If latent load of space including infiltration of humid outdoor air and human load could be handled by low volume supply air of DOAS, there would be no need to recondition indoor air.

The air distribution type in high temperature cooling applications also varies depending on types of HTC device and space cooling load characteristics. This could vary from mixing strategy like ceiling supply - ceiling exhaust to displacement oriented distribution types like DV or floor supply - ceiling exhaust. In the reported studies of HTC applications, air supply temperature ranged between 14 to $19^{\circ} \mathrm{C}$ and ventilation rate was around 1 to $2 \mathrm{lit} / \mathrm{s} / \mathrm{m}^{2}$ or 5 to $10 \mathrm{lit} / \mathrm{s} /$ person based on $5 \mathrm{~m}^{2}$ per person occupancy rate. This level of ventilation is above the minimum ventilation requirement of Singapore standard SS 553 [51] which is 5.5 lit/s/person. The chosen range of supply temperature in this concept may not satisfy the local comfort criteria for distribution strategy of DV and FS-CE. A numerical study on the implementation of DDOAS-RCS under FS-CE distribution [52] concluded that with off coil air temperature of $14{ }^{\circ} \mathrm{C}$, in the areas close to floor diffusers, air could be around $17^{\circ} \mathrm{C}$ which raises the concerns of cold feet for occupants seated there.

Dehumidification of ventilation air requires low temperature chilled water while HTC system is designed to operate with high temperature chilled water. The selection of design and control strategy for providing both LTCW and HTCW at the same time has an important impact on optimal operation and energy efficiency of the system. The typical strategy is to produce low temperature chilled water $\left(6^{\circ} \mathrm{C}\right)$ in central plants and employ three way control valves to raise the supply temperature for HTC. The schematic of water hydraulic lines and air ducts in a DOAS combined with radiant panel is shown in Fig. 8. The valve modulator $\left(\mathrm{V}_{2}\right)$ regulates the flow volume in mix of supply and return chilled water in pipes based on 
feedback from temperature sensors $\left(\mathrm{T}_{3}\right.$ or $\left.\mathrm{T}_{4}\right)$. Sastry and Rumsey [25] explored the efficiency and robustness of different control strategies and found that controlled valves based on fixed return water temperature perform the best. The second strategy is to keep chilled water loop of HTC and LTC separate and use a water to water heat exchanger to transfer the cooling to HTC loop. The schematic of a VAV-RCP with two separate hydronic system loops is shown in Fig. 9. The return water from AHU passes through a heat exchanger to provide a supply chilled water of $15^{\circ} \mathrm{C}$ for radiant ceiling panel operation. This strategy has been implemented mostly in research labs to have a better control on operation of high temperature cooling device $[27,45]$. The third strategy is to use two separate chillers and water hydronic loops for HTC and LTC systems as explained in Section 2.1 (Fig. 3). This scheme has the potential to introduce further energy saving opportunities especially for the applications where more than one chiller has been designated for cooling of building.

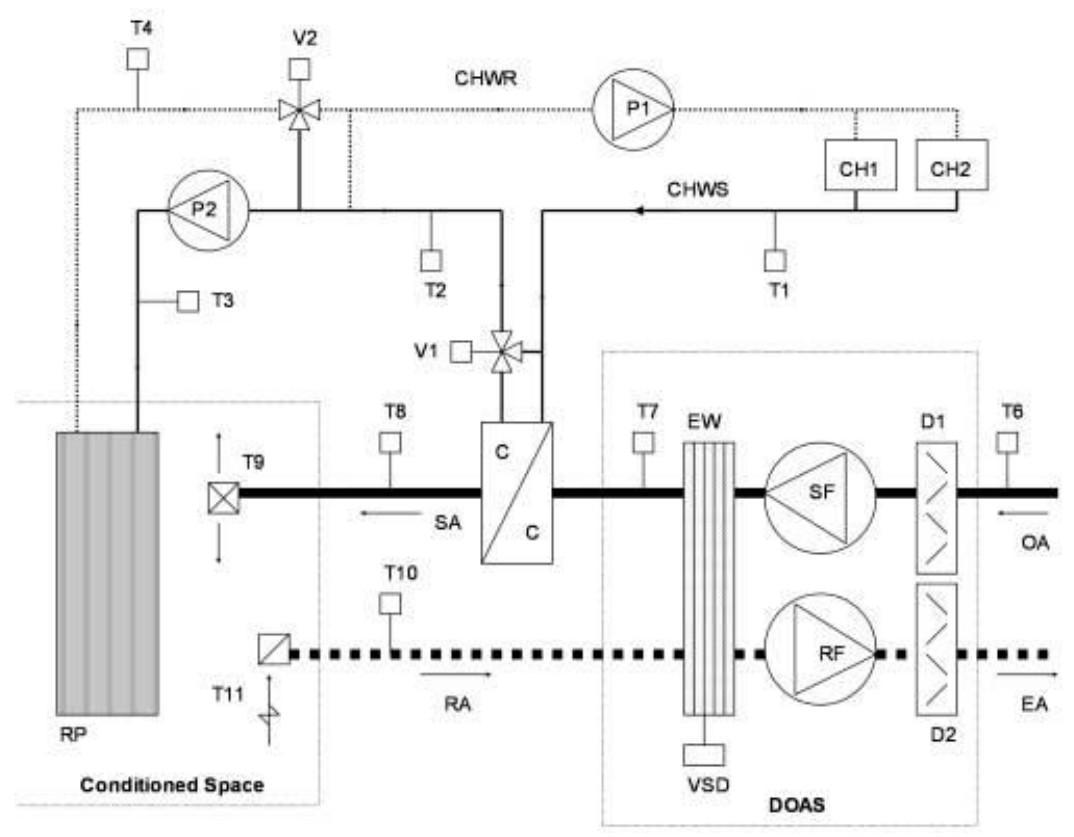

Fig. 8 Water hydronic lines and air streams in a DOAS combined with radiant panel [53] (SF: supply fan, RF: return fan, P 1-2: pumps, C/C: cooling coil, T 1-11: temperature sensors, D 1-2: Dampers, V 1-2: valve modulators, EW: Enthalpy wheel, RP: radiant panel, CH 1-2: chillers) 


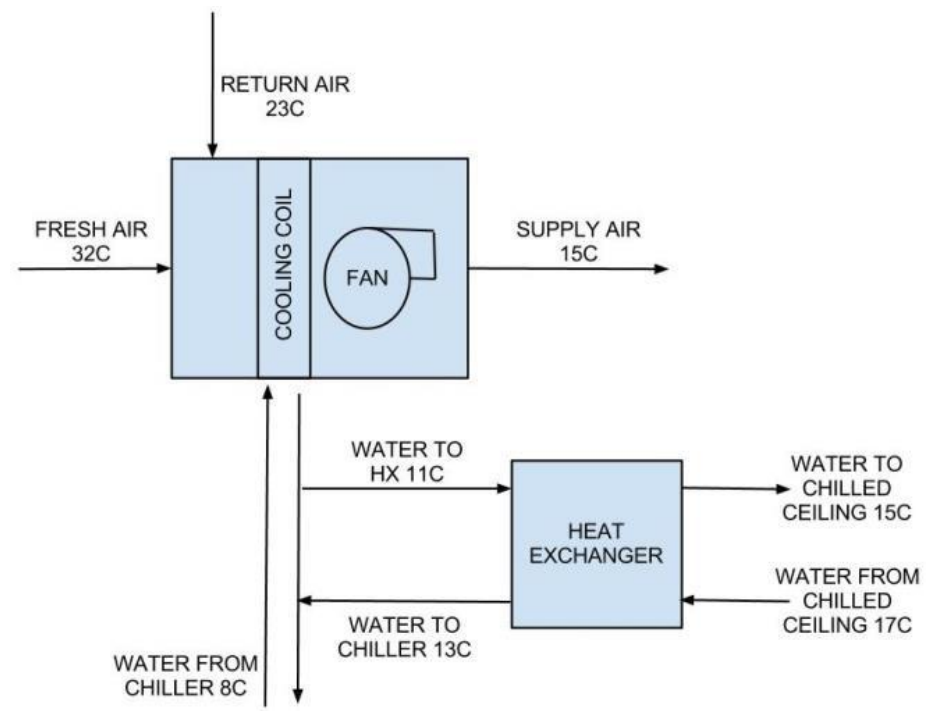

Fig. 9 Employing a heat exchanger to provide high temperature chilled water in a VAV-

RCP system [27]

Because of concerns regarding to condensation in tropical buildings, the start up and shut down strategy of HTC system needs to be well planned and followed. Kosonen and Tan [15] concluded that air based system needs to be switched on 30 minutes before water based system in the morning in order to get rid of stored humidity in the space over the night. This amount of time was estimated for a building with air tight façade and it could vary based on characteristics of building. It is also advisable to switch off HTC device before air based system to avoid any possible condensation after scheduled occupancy. In the case of slab cooling system implementation, energy saving concerns also comes into play in choosing the right start up and shut down strategy. Because of stored cooling capacity in slab due to thermal mass, it is required to operate the radiant system in a shifted schedule compared to occupancy schedule. One case study in the tropics recommended to switch on slab cooling system one to two hours before occupancy and to switch it off one to two hours before unoccupancy [25]. Khan et al. [28] also explored various control strategies for operation of slab cooling system in the tropical climate of Hyderabad in India and concluded that maximum energy saving can be achieved when slab cooling system shut off four hours before end of occupancy schedule. 


\subsection{Investment and maintenance costs}

Investment cost required for different HVAC systems is usually the key decision factor for selection of a design especially when building investors and users are two different parties. The cost of equipments and labors are geographic dependent and they also could vary based on market demand and scale of manufacturing. A study conducted side by side comparison of VAV and slab cooling system in the Hyderabad of India and concluded that capital cost of DOAS-RSC is slightly lower than VAV system [25]. The cost saving opportunities from reduction of AHU and duct size was about $6 \%$ of total cost of ACMV system while radiant piping, accessories and installation raised the investment cost for around $23 \%$. The study considered $33 \%$ reduction in HVAC low side work or commissioning cost in the case of radiant cooling. In another study, Mumma [4] compared the first cost of DOAS-Radiant panel with all air VAV system for a six storey building in the context of Philadelphia, in US. He showed that total cost benefits of radiant cooling system through reduction of AHU, ductwork and floor to floor height as well as integration with electrical and fire suppression services could outweigh the added cost of radiant panels. However, for the application of active chilled beams in the context of California in US, Stein and Taylor [54] estimated that total cost of DOAS-ACB system is about 2.5 times of VAVR design. They considered additional labor and subcontractors costs for ACB design and installation.

High temperature cooling concept is a new design for the tropical context and its practical implications have not been investigated explicitly for this climate. Having cooling coil and chilled water inside the conditioned space requires further inspection and possibly higher maintenance cost. In the case of active and passive chilled beam, a regular cooling coil cleaning service is required to avoid losing part of units' capacity over time because of collected dust on coils. The panel metal sheet and chilled water pipe behind the radiant cooling 
panel also may require regular cleaning service. In order to reduce the risk of condensation in applications of slab cooling system in the tropics, it was advised to insulate all water pipe connections and manifolds [25].

\section{Integration with energy recovery systems}

In applications of high temperature cooling system, DOAS as the parallel air based system can provide better performance and lower first cost opportunities compared to RAS due to reduction in the size of AHU, ducting and fan energy use. The enthalpy difference between the two air streams of fresh outdoor and indoor exhaust is significant and an energy recovery system can reduce part of ventilation cooling load. Different types of ERS devices have been introduced and investigated in the literature and industry. Rotary desiccant dehumidifier (RDD) is one of these designs which incorporates a rotary wheel with desiccant coated honeycombs for exchange of humidity. In active type of rotary desiccants (Fig. 10), a heat source is required to activate the regeneration air streams in order to enhance the mass transfer mechanism in the wheel. The warm and humid process air gets dehumidified after exchange of humidity with regeneration air and then it is supplied into indoor space. The required heat source is the main constraints for this design which is not easily accessible in the tropical climate. Alongside this design, there is passive type of rotary desiccant in which the wheel is placed between OA and EA streams and energy recovery happens without help of heat source. In the passive RDD applications, the wheel needs to rotate at much faster speed compared to active types [55]. 


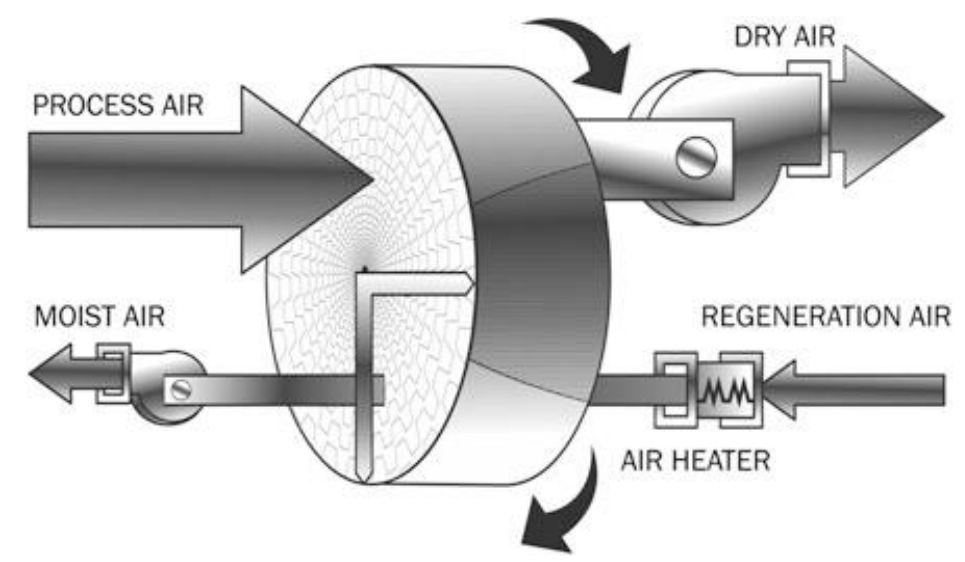

Fig. 10 Active type of rotary desiccant wheel with air heater [55]

Several studies in the literature tried to explore the application of high temperature cooling system combined with active rotary desiccant dehumidification in the tropics. Ameen and Khizir [14] evaluated the performance of an active desiccant dehumidification system coupled with chilled ceiling in the tropical climate of Malaysia. They found that this combination has superior performance over conventional system in applications where high ventilation rate is required like in theatres and hospitals. In another study in Singapore, Wahed et al. [18] conducted energy simulation to investigate the performance of a thermally regenerated desiccant system integrated with chilled beam in the warm and humid climates. They modelled the active RDD with three different heating sources for regeneration process including electric heater, solar collector and waste heat. The annual energy simulation and economic analysis revealed that solar assisted dehumidifier integrated with active chilled beam is the most cost effective design which consumes 10-20\% less energy than conventional VAV system in the tropics.

Membrane based air to air heat exchanger is another type of energy recovery systems which is getting wide range applications in the industry. In this design, heat and humidity transfers between two air streams happen at a porous membrane surface without any active parts inside the device. Air streams inside the heat exchanger can interact in different 
arrangements as parallel, counterflow or cross flow streams [56]. During this interaction, outside air loses some level of its heat and humidity to dry and cool exhaust air leaving the indoor space. Nasif et al. [57] evaluated the performance of a $\mathrm{Z}$ type parallel plate heat exchanger (Fig. 11) made of porous membrane. In this $\mathrm{Z}$ type design configuration, three arrangement scenarios of parallel flow, counter flow and cross flow happen between two air streams inside the heat exchanger. The results of experiments and annual energy simulations showed that implementing this enthalpy heat exchanger in air conditioning system can result in 5.7 to $9 \%$ energy saving for the tropical climate of Kuala Lumpur.

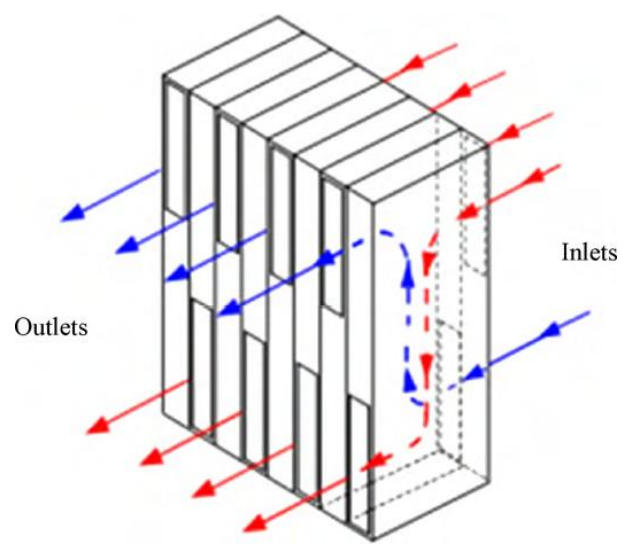

Fig. 11 "Z" type membrane based heat exchanger [57]

\section{Direct connection to cooling tower}

Incorporating high temperature cooling systems in building could bring the opportunity to implement passive chilled water systems like cooling tower to provide the required HTCW without use of refrigeration system. Outdoor wet bulb temperature is the key parameter for this design which usually ranges between 25 to $26^{\circ} \mathrm{C}$ in the tropics except in the dry season for the tropical savanna climate. Cooling tower can provide chilled water in the range of 25 to $26{ }^{\circ} \mathrm{C}$ for the radiant cooling system. However, this level of chilled water temperature cannot 
provide effective cooling in HTC device for day time applications in office spaces. Vangtook and chirarartaran [17] investigated different operational and design scenarios for the application of cooling tower to provide high temperature chilled water for radiant cooling panel in Thailand. The results showed that this system can provide adequate indoor condition for spaces with low heat gain in night time applications. Tantiwichien and Taweekun [24] also investigated the performance of radiant cooling panel using chilled water from an employed cooling tower in the tropical climate of Thailand through experiments and simulations. The results showed that this design is able to provide comfortable indoor condition during night time and early morning with $41 \%$ energy saving compared to split-type air conditioner. The performance of incorporated cooling tower in this design was around $60 \%$ which varied depending on outdoor dry bulb and wet bulb temperatures.

\section{Discussions}

The whole idea behind implementing high temperature cooling systems in buildings is to introduce a more energy efficient cooling system compared to the conventional all air system. A precise and detailed design strategy needs to be followed in order to truly utilize the potential benefits of HTC systems. It was shown by several studies in the literature [17,28] that fan energy use can be reduced by 50 to $70 \%$ through incorporating DOAS combined with radiant cooling system. Downsizing fan and duct size in ACMV system compared to conventional design is the key factor for achieving higher energy saving in this concept. Providing an air tight façade for the indoor space is necessary to minimize the infiltration rate and latent load of space, especially in the tropical context where outdoor humidity is high all year round. In the ideal operational scenario, the amount of supply air volume is in the range of minimum ventilation requirement of space and HTC plays a significant role in satisfying the sensible load of space. 
HTC systems operate with high temperature chilled water which can bring the potential to enhance the operational efficiency of chiller in buildings. Two separate chillers could to be installed in buildings to provide LTCW and HTCW for air and water systems, respectively. This design strategy suits the buildings where multiple chillers were assigned to be operational. The potential energy saving of this separation can be understood from the reverse theoretical thermodynamic cycle of Carnot. This cycle is the most efficient possible set of processes to transfer a certain amount of heat from a cold source $\left(\mathrm{Q}_{\mathrm{C}^{-}} \mathrm{T}_{\mathrm{C}}\right)$ to a hot one $\left(\mathrm{Q}_{\mathrm{H}^{-}} \mathrm{T}_{\mathrm{H}}\right)$ with a given amount of usable work (W). The COP of the cycle in the tropical context (average outdoor temperature of $30{ }^{\circ} \mathrm{C}$ ) for the low temperature $\left(6{ }^{\circ} \mathrm{C}\right)$ and high temperature $\left(16^{\circ} \mathrm{C}\right)$ cooling operations can be determined as follows,

COP $P_{\text {Cooling }}=\frac{Q_{C}}{W}=\frac{Q_{C}}{Q_{H}-Q_{C}}=\frac{T_{C}}{T_{H}-T_{C}} \quad E q .1$

$\operatorname{COP}_{\text {Carnot, low temperature }}=\frac{T_{c}}{T_{h}-T_{c}}=\frac{273.15+6}{30-6}=11.6 \quad$ Eq. 2

$\operatorname{COP}_{\text {Carnot, high temperature }}=\frac{T_{c}}{T_{h}-T_{c}}=\frac{273.15+16}{30-16}=20.6 \quad$ Eq.3

Based on the reverse theoretical Carnot cycle, there is a $77 \%$ (Eq. 2-3) increase in operational COP of chillers for high temperature cooling applications in tropical buildings. However, because of the exergy losses in different sub-processes inside the chiller, the COP of actual refrigeration systems operating in cooling system of buildings are far below the theoretical Carnot values. The level of increase in COP for high temperature condition compared to low temperature cooling scenario is also less likely to be in the same order. The chillers in building cooling system are usually designed and regulated to efficiently provide chilled water at temperature of $6-7{ }^{\circ} \mathrm{C}$ which matches the requirement of conventional air 
conditioning system in the buildings. Custom designed chillers for low temperature lift conditions have been introduced and investigated by some research institutes and manufacturing companies for high temperature cooling applications or other process cooling requirements. Doyon [34] investigated the critical design parameters of centrifugal chillers for superior efficiency at low temperature lift conditions. He found open-drive/gear-drive compressors with variable orifice and oil education system as the most suitable features in chillers for high temperature cooling applications. He also concluded that chillers with hermetic drive motors would not be able to utilize the potential energy saving of HTC operational conditions due to required high head pressure for cooling of motor windings. In another investigation, Wyssen et al. [58] designed a chiller prototype for low temperature lift conditions which was equipped with a semi-hermetic reciprocating compressor. The outcomes of experiments showed that at evaporative temperature of $15{ }^{\circ} \mathrm{C}$, the $\mathrm{COP}$ of this chiller increases from 4 at $40{ }^{\circ} \mathrm{C}$ temperature lift to about 11.4 at $13{ }^{\circ} \mathrm{C}$ lift. The $\mathrm{COP}$ of this custom designed chiller as well as ideal Carnot and typical chillers are plotted in Fig. 12. It can be seen that performance curve of this prototype chiller fits in between typical chillers and ideal efficiency curves. The low lift chiller performs better than air cooled/water cooled chillers both in terms of COP value at any specific lift and increase rate for lower temperature lift. This shows some part of exergy losses in chiller sub-processes has been eliminated in this design. 


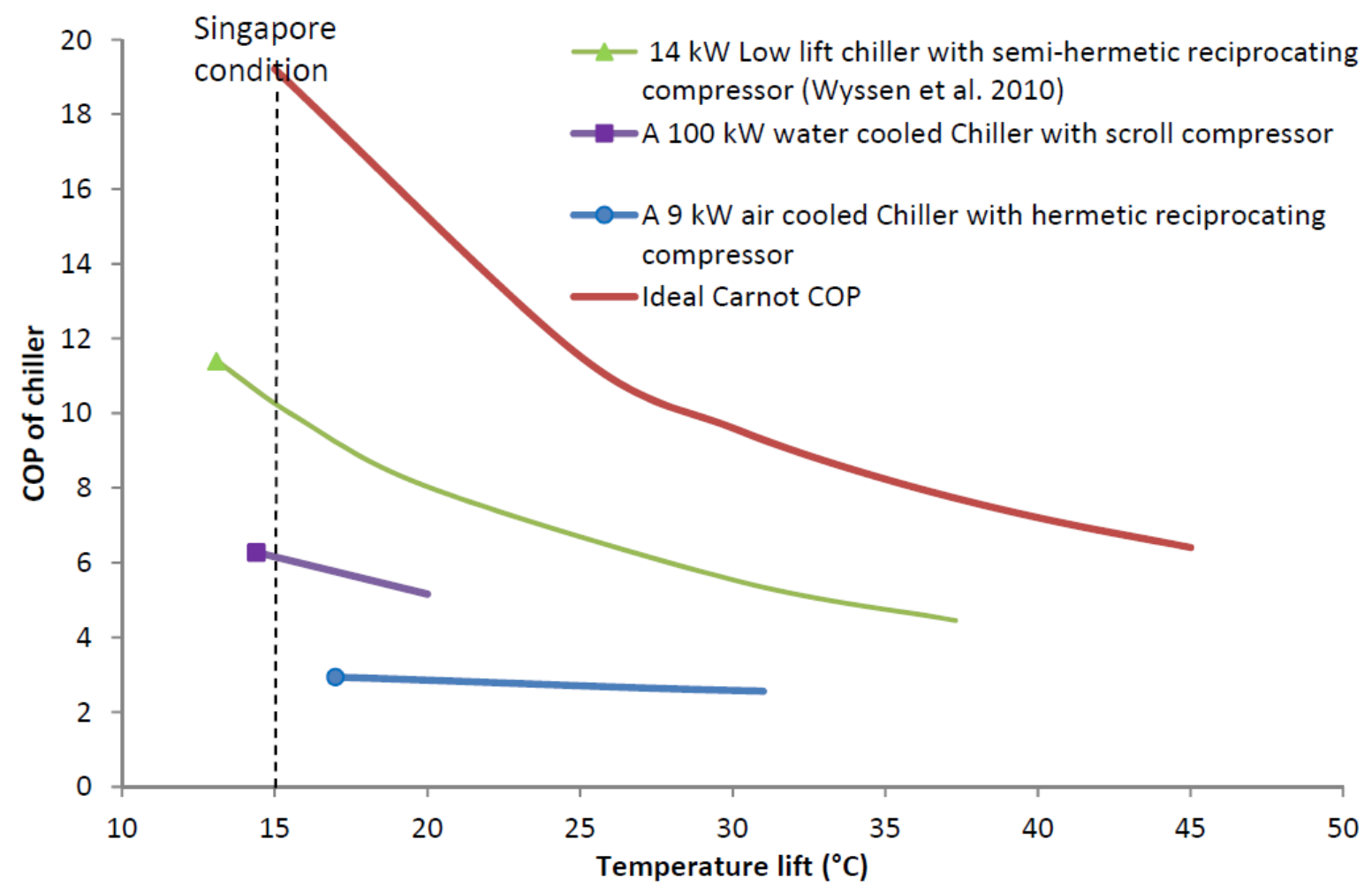

Fig. 12 COP of ideal Carnot cycle, low lift chiller and two typical air cooled/water cooled chillers at evaporative temperature of $15^{\circ} \mathrm{C}$

The application of high temperature cooling in tropical buildings can be categorized based on their supply chilled water temperature to HTC device. When the supply water temperature is above the outdoor dew point level and in the range of 25 to $26{ }^{\circ} \mathrm{C}$, it can only provide comfortable indoor space for night time applications. This design scheme could also be used during day time in office buildings with low space heat gain for occupants under light clothing level when personalized or ceiling fans are used to raise the air movement on work stations. In the second design scheme, chilled water is supplied to HTC at temperatures lower than outdoor dew point and comfortable indoor space can be achievable under any indoor/outdoor scenarios. In this scheme, the parallel conditioned air system would keep the indoor dew point below HTC operating temperature to avoid condensation. The only reported deficiency in the literature for this conditioned indoor space is the low air movement as locally acclimatized 
occupants in the tropics prefer to be exposed to higher air speed. This issue has been resolved by using a ceiling fan in the office space for an implemented case of radiant cooling system [25].

Different strategies have been investigated and suggested in the literature for the design and operation of HTC in tropical buildings. A detailed control strategy is required to be followed especially in the cases where HTC operational temperature is below outdoor dew point to avoid condensation. The start up and shut down schemes could vary based on type of HTC system and characteristics of buildings. In the case of slab cooling system, a shift needs to be considered between operational schedule of HTC and occupancy period. For other types of HTC systems located in the indoor space, the air based system should be switched on /off before/after water based system in the morning and evening, respectively. The choice of air conditioning and distribution system could also play an important role in energy saving and thermal comfort of occupants. DOAS was found to be the best parallel air based system and from energy efficiency point of view, the amount of supply air is best to be kept near minimum ventilation requirements of space. In spaces with high latent load, supply air volume to space may be required to exceed this minimum requirement. Since in this design scenario, the off coil temperature would be in the range of 14 to $16{ }^{\circ} \mathrm{C}$, it is advisable to implement ceiling supply-ceiling exhaust distribution instead of displacement strategy to avoid cold feet for occupants.

The initial cost of high temperature cooling system varies based on HTC device types and radiant slab cooling is the least costly choice. However, this design needs to be planned at early stages before construction of building structure. The added cost of piping and accessories to overall ACMV design could be mitigated by reduction of fan and duct size for circulation of air in buildings. Less floor to floor height and integration with lighting and fire suppression systems are other potential opportunities for saving material and space per floor area. In order 
to utilize these potential benefits for implementation of high temperature cooling system, the coordination of building structural, mechanical, electrical and fire protection contractors is required. The maintenance cost of HTC system is also expected to be higher due to significantly higher water pipes compared to conventional all air system especially in the case of passive/active chilled beams.

The advantages of water based system combined with DOAS can be further utilized if an energy recovery system is incorporated into air handling unit. The high enthalpy difference between outdoor and indoor air in the tropics makes implementation of ERS more economically feasible. Several studies in the literature reported significant energy saving for coupling of HTC and active rotary desiccant dehumidification in the tropics through experimental setup or simulation. Solar assisted heating was found as the best strategy for the required heating in the regeneration process, although this source is not reliable in the tropics due to high annual median cloud cover. Membrane heat exchangers (MHX) have also been explored in the literature in the tropical context and promising performance was observed for this design [50].

A collection of high temperature cooling design strategies and components in tropical building based on reported outcomes in the literature is shown in Fig. 13. User controlled temperature and humidity sensors are considered in indoor space to provide necessary changes on operation of water and air based systems based on different indoor/outdoor scenarios. With increase of humidity or dew point temperature above the specified threshold, signal would be sent to actuators on air supply units' pumps and three way control valve to reduce water supply temperature and/or increase water flow rate. This change would enhance dehumidification capacity of air system to avoid any risk of condensation on radiant panel. Three way control valve and pump on HTC hydronic system could modulate its capacity based on feedback from temperature sensors to provide the required sensible cooling for 
space. Installing $\mathrm{CO}_{2}$ sensors can also bring further value to this design for the thermal zones where there is high variation of occupancy level like in meeting rooms. Based on these sensors' feedback, the volume of fresh air coming into space could be regulated through modulating supply air fan speed.

In this design strategy (Fig. 13), an energy recovery system is designated for DOAS to recuperate some part of cooling from exhaust air stream. This ERS device could be an active/passive desiccant wheel or a membrane based air to air heat exchanger which transfers heat and humidity between two air streams. The high enthalpy difference between indoor and outdoor condition in the tropical context would make ERS an effective system for the applications of DOAS. In addition, the required high temperature chilled water for HTC can be provided through alternative strategies like cooling tower or a separate low lift chiller. Direct connection of HTC to cooling tower without refrigeration system is mostly suitable for spaces with low heat gain in night time applications. A custom designed chiller which operates at considerably higher efficiency in low temperature lift applications can also be a more efficient solution compared to a central low temperature chilled water (LTCW) system. The level of improvement in COP of designated low lift chiller needs to outweigh the added cost of having a separate chiller for HTC, in order for this alternative solution to be economically competitive 


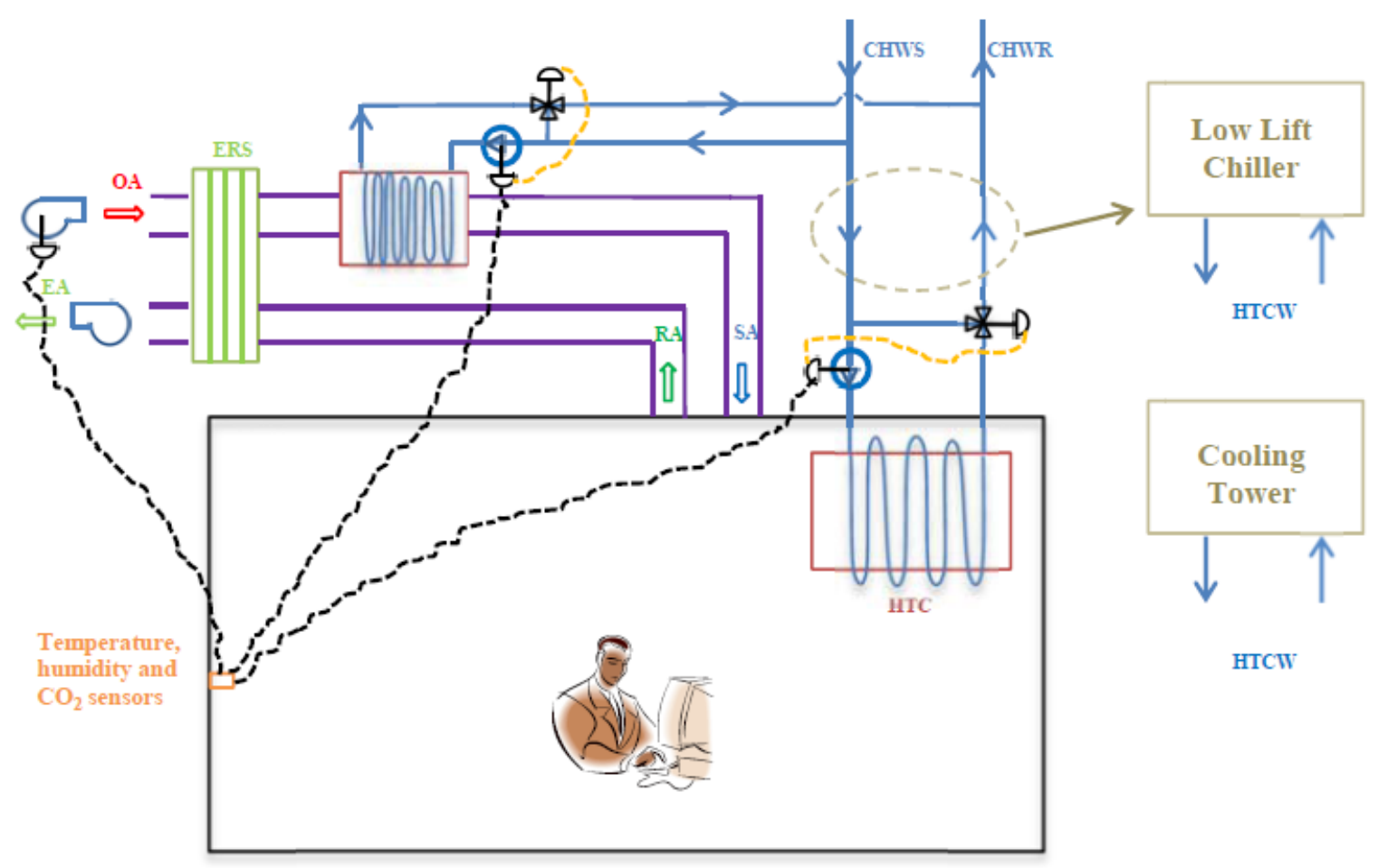

Fig. 13 A selected design strategies and components for the application of high temperature cooling in the tropics

\section{Conclusions}

The reported studies in the literature on the implementation of high temperature cooling systems in the tropics were reviewed to get a better understanding on overall performance of this cooling strategy for the warm and humid climates. Various aspects of this implementation were explored in terms of energy saving and thermal comfort for locally acclimatized occupants as well as optimal design and operational scenarios. The outcomes of this investigation can be summarized in the following points,

- HTC systems can bring the opportunity to downsize fan and duct size for air circulation and cut the fan energy use by half compared to all air system

- In the tropical context, an air tight façade is preferable for this strategy to minimize the infiltration rate or in other words the latent load of space 
- Incorporating a custom designed chiller for low temperature lift conditions can further utilize the potential energy saving of this concept

- When supply chilled water temperature to HTC is above the outdoor dew point level, comfortable indoor condition can be achieved only under specific indoor/outdoor conditions. This high temperature water can be provided with direct connection to cooling tower without use of refrigeration system in the tropics.

- When supply chilled water temperature to HTC is below the outdoor dew point level, comfortable condition is achievable under any indoor/outdoor conditions. Although a parallel conditioned air system is required to avoid condensation on HTC device. The low air movement in this indoor space was the only reported comfort concern for locally acclimatized occupants in the tropics.

- A control strategy needs to be followed to avoid condensation in start up and shut down period of system in tropical buildings. In the case of slab cooling system, a shift between operational schedule of HTC and occupancy period needs to be considered.

- DOAS with ceiling supply-ceiling exhaust was found as the most suitable and efficient air conditioning and distribution strategy for HTC implementation.

- Among HTC cooling systems, slab cooling can be implemented at lower initial cost. However, it requires early-stage planning and integration into structure of building.

- Incorporation of energy recovery system into DOAS can reduce ventilation cooling load of space and improve the overall performance of HTC design. Membrane based air to air heat exchangers showed promising performance in the tropical context. 
The practical implications of high temperature cooling system are required to be further explored through actual implementation of this concept into tropical buildings. This coupled air/water system demands a more sophisticated design and control strategy compared to all air system. Thoughtful decisions need to be made at design stage based on experience of past projects and building performance simulation for a successful implementation of high temperature cooling strategy in the tropics.

\section{Acknowledgment}

This work was established at the Singapore-ETH Centre for Global Environmental Sustainability (SEC), co-funded by the Singapore National Research Foundation (NRF) and ETH Zurich in collaboration with department of building of NUS.

\section{References}

[1] NEA, Singapore's Second National Communication: Under the United Nations Framework Convention on Climate Change, National Environmental Agency, 2010.

[2] A. Novoselac, J. Srebric, A critical review on the performance and design of combined cooled ceiling and displacement ventilation systems, Energy Build. 34 (2002) 497-509. doi:10.1016/S0378-7788(01)001347.

[3] Z. Tian, J.A. Love, Application of radiant cooling in different climates: assessment of office buildings through simulation, in: Elev. Int. IBPSA Conf., 2009.

http://www.ibpsa.org/proceedings/BS2009/BS09_2220_2227.pdf (accessed August 21, 2013).

[4] S.A. Mumma, Chilled Ceilings in Parallel with Dedicated Outdoor Air Systems: Addressing the Concerns of Condensation, Capacity, and Cost, ASHRAE Trans. 108 (2002).

[5] S.A. Mumma, Condensation issues with radiant cooling panels, IAQ Appl. 2001. (2001) 16-18.

[6] E.M. Saber, M. Mast, K.W. Tham, H. Leibundgut, Ventilation effectiveness and contaminant distribution in an occupied space conditioned with low exergy ventilation technologies in the tropics, in: Eindhoven, Netherlands, 2015.

[7] W.-H. Chiang, C.-Y. Wang, J.-S. Huang, Evaluation of cooling ceiling and mechanical ventilation systems on thermal comfort using CFD study in an office for subtropical region, Build. Environ. 48 (2012) 113-127. doi:10.1016/j.buildenv.2011.09.002.

[8] W. Wang, Z. Tian, Indoor thermal comfort research on the hybrid system of radiant cooling and dedicated outdoor air system, Front. Energy. 7 (2013) 155-160. doi:10.1007/s11708-013-0244-z.

[9] S. Schiavon, F. Bauman, B. Tully, J. Rimmer, Room air stratification in combined chilled ceiling and displacement ventilation systems, HVACR Res. 18 (2012) 147-159. doi:10.1080/10789669.2011.592105.

[10] B.W. Olesen, Radiant Floor Cooling Systems, ASHRAE J. 50 (2008) 16-22.

[11] J. (Dove) Feng, S. Schiavon, F. Bauman, Cooling load differences between radiant and air systems, Energy Build. 65 (2013) 310-321. doi:10.1016/j.enbuild.2013.06.009.

[12] M.C. Peel, B.L. Finlayson, T.A. McMahon, Updated world map of the Köppen-Geiger climate classification, Hydrol Earth Syst Sci. 11 (2007) 1633-1644. doi:10.5194/hess-11-1633-2007. 
[13] WeatherSpark, Weather Graphs and Maps - WeatherSpark, (n.d.). https://weatherspark.com/ (accessed November 24, 2015).

[14] A. Ameen, K. Mahmud, Desiccant Dehumidification with Hydronic Radiant Cooling System for AirConditioning Applications in Humid Tropical Climates, ASHRAE Trans. 111 (2005) 225-237.

[15] R. Kosonen, F. Tan, A feasibility study of a ventilated beam system in the hot and humid climate: a casestudy approach, Build. Environ. 40 (2005) 1164-1173. doi:10.1016/j.buildenv.2004.11.006.

[16] P. Vangtook, S. Chirarattananon, An experimental investigation of application of radiant cooling in hot humid climate, Energy Build. 38 (2006) 273-285. doi:10.1016/j.enbuild.2005.06.022.

[17] P. Vangtook, S. Chirarattananon, Application of radiant cooling as a passive cooling option in hot humid climate, Build. Environ. 42 (2007) 543-556. doi:10.1016/j.buildenv.2005.09.014.

[18] M.A. Wahed, Y.W. Wong, K.C. Toh, H.K. Ho, Performance Analysis of Thermally Regenerated Desiccant System Integrated With Chilled Beam for Warm Humid Climate, in: ASME 2010 Int. Mech. Eng. Congr. Expo., 2010: pp. 1375-1382. doi:10.1115/IMECE2010-40263.

[19] A.S. Binghooth, Z.A. Zainal, Performance of desiccant dehumidification with hydronic radiant cooling system in hot humid climates, Energy Build. 51 (2012) 1-5. doi:10.1016/j.enbuild.2012.01.031.

[20] E.M. Saber, R. Iyengar, M. Mast, F. Meggers, K.W. Tham, H. Leibundgut, Thermal comfort and IAQ analysis of a decentralized DOAS system coupled with radiant cooling for the tropics, Build. Environ. 82 (2014) 361-370. doi:10.1016/j.buildenv.2014.09.001.

[21] F. Meggers, J. Pantelic, L. Baldini, E.M. Saber, M.K. Kim, Evaluating and adapting low exergy systems with decentralized ventilation for tropical climates, Energy Build. 67 (2013) 559-567. doi:10.1016/j.enbuild.2013.08.015.

[22] R.S. Iyengar, E. Saber, F. Meggers, H. Leibundgut, The feasibility of performing high-temperature radiant cooling in tropical buildings when coupled with a decentralized ventilation system, HVACR Res. 19 (2013) 992-1000. doi:10.1080/10789669.2013.826065.

[23] Y.H. Yau, S. Hasbi, Field analysis of indoor air quality in high rise and low rise green offices with radiant slab cooling systems in Malaysia, Indoor Built Environ. (2013) 1420326X13506130. doi:10.1177/1420326X13506130.

[24] A.-U.-W. Tantiwichien, J. Taweekun, An Experimental and Simulated Study on Thermal Comfort, IACSIT Int. J. Eng. Technol. 5 (2013) 177-180.

[25] G. Sastry, P. Rumsey, VAV vs. Radiant Side-by-Side Comparison, ASHRAE J. 56 (2014) 16-24.

[26] N. Nutprasert, P. Chaiwiwatworakul, Radiant Cooling with Dehumidified Air Ventilation for Thermal Comfort in Buildings in Tropical Climate, Energy Procedia. 52 (2014) 250-259. doi:10.1016/j.egypro.2014.07.076.

[27] B. Seshadri, M.B.H. Sapar, Z. Jian, M. Neth, B. Wu, D. Ng, Feasibility Study of Chilled Ceiling Technology in Singapore through Simulation and Verification, in: Build. Simul. Optim. Conf., London, 2014.

https://www.academia.edu/7511381/Feasibility_Study_of_Chilled_Ceiling_Technology_in_Singapore_th rough_Simulation_and_Verification (accessed June 9, 2015).

[28] Y. Khan, V.R. Khare, J. Mathur, M. Bhandari, Performance evaluation of radiant cooling system integrated with air system under different operational strategies, Energy Build. 97 (2015) 118-128. doi:10.1016/j.enbuild.2015.03.030.

[29] M. Bruelisauer, K. Chen, R. Iyengar, H. Leibundgut, C. Li, M. Li, Mast M, Meggers F, Miller C, Dino R,

Saber EM, Schlueter A, Tham KW., BubbleZERO-Design, Construction and Operation of a Transportable Research Laboratory for Low Exergy Building System Evaluation in the Tropics, Energies. 6 (2013) 4551-4571. doi:10.3390/en6094551.

[30] E. Saber, F. Meggers, R. Iyengar, The potential of low exergy building systems in the tropics - Prototype evaluation from the BubbleZERO in Singapore, in: Proc. Clima 2013 Energy Effic. Smart Healthy Build., Prague, Czech Republic, 2013.

[31] IEA ECBCS Annex 28, Low Energy Cooling Systems, UK, Coventry, 2000.

[32] IEA ECBCS Annex 37, Low Exergy Systems for Heating and Cooling Buildings - Guidebook, VTT Technical Research Centre of Finland, 2003.

[33] IEA ECBCS Annex 49, Low Exergy Systems for High-Performance Buildings and Communities, Frauenhofer Institute for Building Physics, 2010. http://www.annex49.com.

[34] T. Doyon, Chiller Design For Low-Lift Conditions, Air Cond. Heat. Refrig. News. 234 (2008) 13-15.

[35] M. Indraganti, R. Ooka, H.B. Rijal, G.S. Brager, Adaptive model of thermal comfort for offices in hot and humid climates of India, Build. Environ. 74 (2014) 39-53. doi:10.1016/j.buildenv.2014.01.002.

[36] H.C. Willem, K.W. Tham, Associations between thermal perception and physiological indicators under moderate thermal stress, in: 6th Int. Conf. Indoor Air Qual. Vent. Energy Conserv. Build. Sustain. Built Environ., 2007. http://scholarbank.nus.edu.sg/handle/10635/45914 (accessed June 16, 2014). 
[37] N. Gong, K.W. Tham, A.K. Melikov, D.P. Wyon, S.C. Sekhar, K.W. Cheong, The Acceptable Air Velocity Range for Local Air Movement in The Tropics, HVACR Res. 12 (2006) 1065-1076. doi:10.1080/10789669.2006.10391451.

[38] W.A. Andreasi, R. Lamberts, C. Cândido, Thermal acceptability assessment in buildings located in hot and humid regions in Brazil, Build. Environ. 45 (2010) 1225-1232. doi:10.1016/j.buildenv.2009.11.005.

[39] ASHRAE 55, ANSI/ASHRAE Standard 55-2004: Thermal Environmental Conditions for Human Occupancy, American Society of Heating, Refrigerating and Air-Conditioning Engineers, Atlanta, GA, 2004.

[40] International Standard, ISO 7730:2005 Ergonomics of the thermal environment -- Analytical determination and interpretation of thermal comfort using calculation of the PMV and PPD indices and local thermal comfort criteria, ISO 2005, Geneva, Switzerland, 2005.

[41] SS 554, SS 554 : 2009, Code of practice for indoor air quality for air-conditioned buildings, SPRING Singapore, Singapore, 2009.

[42] MS 1525, Code of Practice on Energy Efficiency and Use of Renewable Energy for Non-Residential Buildings, Department of Standards Malaysia, Putrajaya, Malaysia., 2007.

[43] Q.J. Kwong, M.A. Arsad, N.M. Adam, Evaluation of Indoor Thermal Environment in a Radiant-CooledFloor Office Building in Malaysia, Appl. Mech. Mater. 564 (2014) 228-233. doi:10.4028/www.scientific.net/AMM.564.228.

[44] R. and A.-C.E. American Society of Heating, 2012 ASHRAE Handbook--HVAC Systems and Equipment: AIR-CONDITIONING AND HEATING SYSTEMS, Chap. 6, Panel Heating and Cooling, (2012).

[45] S. Wongkee, S. Chirarattananon, P. Chaiwiwatworakul, A Field Study of Experimental of Radiant Cooling for Residential Building in a Tropical Climate, Jounal Autom. Control Eng. 2 (2014) 67-70.

[46] ISO 11855-3, Building environment design -- Design, dimensioning, installation and control of embedded radiant heating and cooling systems -- Part 3: Design and dimensioning, International Standard Organization, 2012.

[47] P. Rumsey, J. Weale, Chilled Beams in Labs Eliminating Reheat \& Saving Energy on a Budget, ASHRAE J. 49 (2007).

[48] D. Alexander, M. O’Rourke, Design Considerations For Active Chilled Beams, ASHRAE J. (2008) 5058.

[49] M.K. Kim, H. Leibundgut, Evaluation of the humidity performance of a novel radiant cooling system connected with an Airbox convector as a low exergy system adapted to hot and humid climates, Energy Build. 84 (2014) 224-232. doi:10.1016/j.enbuild.2014.08.005.

[50] M.K. Kim, H. Leibundgut, A case study on feasible performance of a system combining an airbox convector with a radiant panel for tropical climates, Build. Environ. 82 (2014) 687-692. doi:10.1016/j.buildenv.2014.10.012.

[51] SS 553, SS $553: 2009$, Code of practice for air-conditioning and mechanical ventilation in buildings, SPRING Singapore, Singapore, 2009.

[52] E. Saber, M. Mast, K.W. Tham, H. Leibundgut, Numerical Modelling of an Indoor Space Conditioned with Low Exergy Cooling Technologies in the Tropics, in: 13th Int. Conf. Indoor Air Qual. Clim., Hong Kong, 2014.

[53] J.-W. Jeong, S.A. Mumma, W.P. Bahnfleth, Energy conservation benefits of a dedicated outdoor air system with parallel sensible cooling by ceiling radiant panels, ASHRAE Trans. 109 (2003) 627-636.

[54] J. Stein, S.T. Taylor, VAV Reheat Versus Active Chilled Beams \& DOAS, ASHRAE J. (2013) 18-32.

[55] C.E.L. Nóbrega, N.C.L. Brum, An Introduction to Solid Desiccant Cooling Technology, in: C.E.L.

Nóbrega, N.C.L. Brum (Eds.), Desiccant-Assist. Cool., Springer London, 2014: pp. 1-23. http://link.springer.com.libproxy1.nus.edu.sg/chapter/10.1007/978-1-4471-5565-2_1 (accessed July 30, 2015).

[56] ASHRAE, Ashrae Handbook: HVAC Systems and Equipment, 2000.

[57] M. Nasif, R. AL-Waked, G. Morrison, M. Behnia, Membrane heat exchanger in HVAC energy recovery systems, systems energy analysis, Energy Build. 42 (2010) 1833-1840. doi:10.1016/j.enbuild.2010.05.020.

[58] I. Wyssen, L. Gasser, B. Wellig, M. Meier, Chiller with small temperature lift for efficient building cooling, in: Proc Clima, Antalya, Turkey, 2010. 